\title{
Final Report on the Groundwater Isotope Project in the Brentwood Region of East Contra Costa County, California
}

\author{
M. Lee Davisson \\ Isotope Sciences Division \\ Lawrence Livermore National Laboratory, \\ Livermore, CA
}

Karla R. Campbell

Department of Geology

Davis, CA

May 1995

Work performed under the auspices of the U.S. Department of Energy by the Lawrence Livermore National Laboratory under Contract W-7405-Eng-48. 


\section{DISCLAIMER}

This document was prepared as an account of work sponsored by an agency of the United States Government. Neither the United States Government nor the University of California nor any of their employees, makes any warranty, express or implied, or assumes any legal liability or responsibility for the accuracy, completeness, or usefulness of any information, apparatus, product, or process disclosed, or represents that its use would not infringe privately owned rights. Reference herein to any specific commercial products, process, or service by trade name, trademark, manufacturer, or otherwise, does not necessarily constitute or imply its endorsement, recommendation, or favoring by the United States Government or the University of California. The views and opinions of authors expressed herein do not necessarily state or reflect those of the United States Government or the University of California, and shall not be used for advertising or product endorsement purposes.

This report has been reproduced directly from the best available copy.

Available to DOE and DOE contractors from the Office of Scientific and Technical Information P.O. Box 62, Oak Ridge, TN 37831

Prices available from (615) 576-8401

Available to the public from the

National Technical Information Service

U.S. Department of Commerce 5285 Port Royal Rd. Springfield, VA 22161 


\section{DISCLAIMER}

Portions of this document may be illegible in electronic image products. Images are produced from the best available original document. 
FINAL REPORT ON THE GROUNDWATER ISOTOPE PROJECT IN THE BRENTWOOD REGION OF EAST CONTRA COSTA COUNTY, CALIFORNIA

by

\author{
M. Lee Davisson \\ Isotope Sciences Division \\ Lawrence Livermore National Laboratory \\ and \\ Karla R. Campbell \\ Department of Geology \\ University of California, Davis
}

May, 1995 
Table of Contents Page

Executive Summary.................................................................................... 1

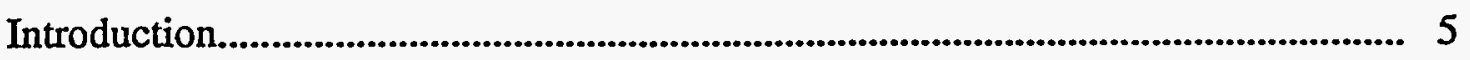

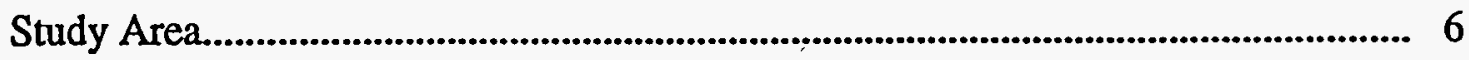

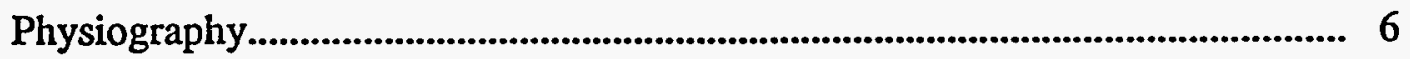

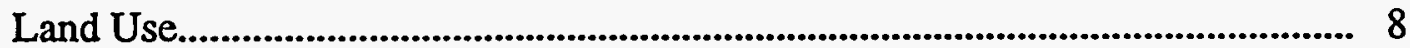

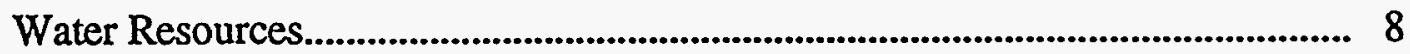

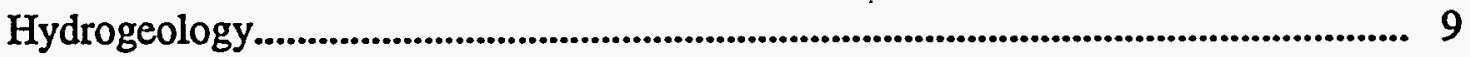

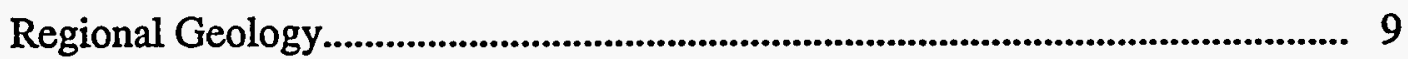

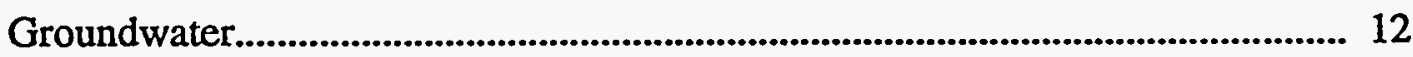

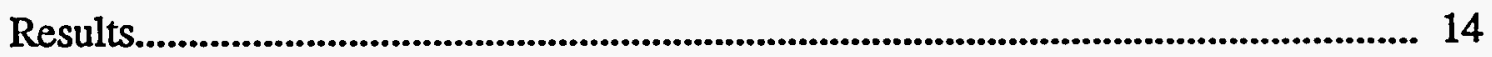

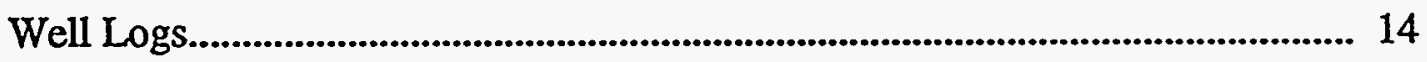

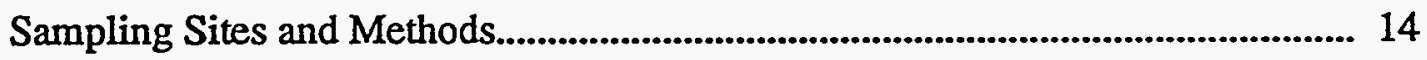

Field Data................................................................................................................. 16

Stable Isotope Data and Groundwater Sources............................................. 19

Radiocarbon Data and Groundwater Ages....................................................... 21

Aqueous Chemistry and Water Quality......................................................... 26

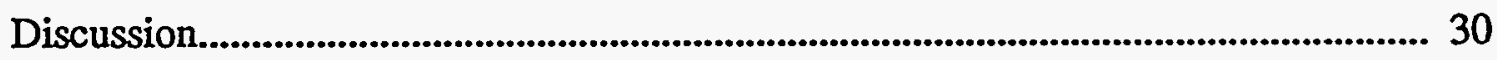

Natural Groundwater Recharge and Flow................................................... 30

Modern Groundwater Recharge................................................................... 34

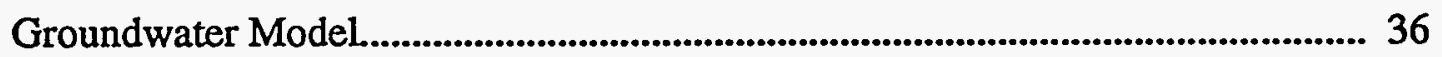

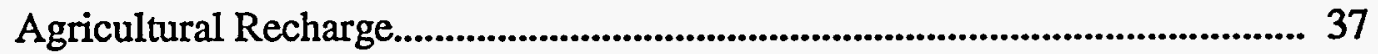

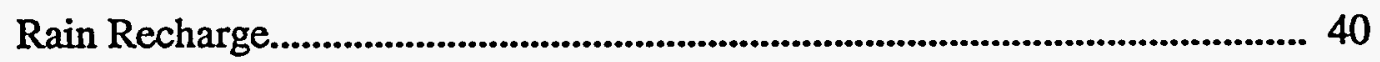

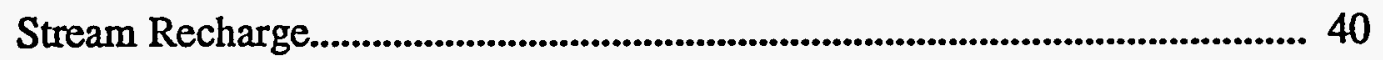

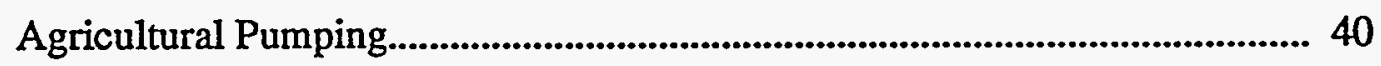

Domestic Pumping.................................................................................... 41

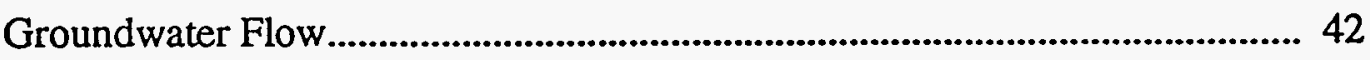


Projected Groundwater Yields.............................................................................. 42

City Production Wells..................................................................................................... 46

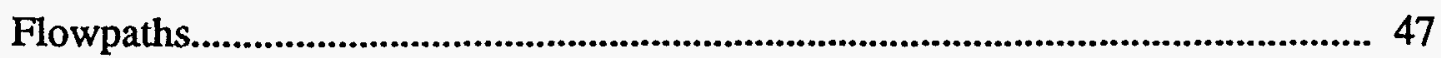

New Groundwater Resources............................................................................. 50

Strategic Management of Regional Groundwater.................................................... 52

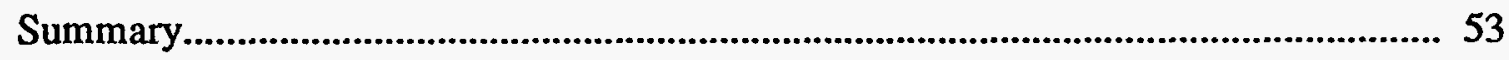

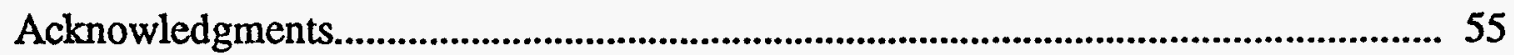

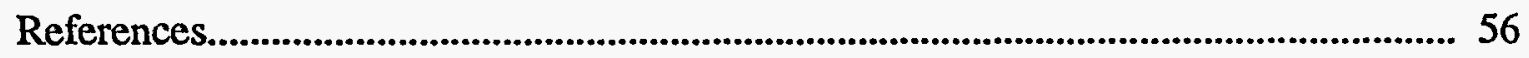

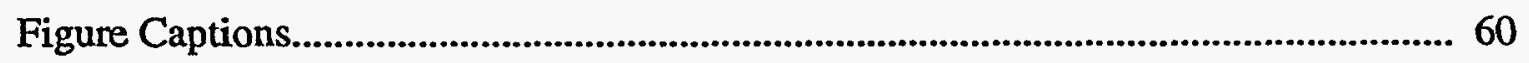




\section{List of Figures}

Figure 1: Location map of study area and wells sampled.

Figure 2: Map of surface soil types in the Brentwood region.

Figure 3: Plot of nitrate concentrations over time for Brentwood city wells.

Figure 4: Summary of geologic stratigraphy in the Central Valley.

Figure 5: General geologic map of the mid-western Central Valley.

Figure 6: 1982 groundwater levels in the Brentwood region.

Figure 7a: Density of groundwater wells in the Brentwood region.

Figure 7b: Contour map of average well perforations in the Brentwood region.

Figure 8a: Contour map of nitrate in the Brentwood region groundwater.

Figure 8b: Cross section of nitrate in the Brentwood region groundwater.

Figure 9: $\delta \mathrm{D}-\delta^{18} \mathrm{O}$ plot of groundwaters from the Brentwood region.

Figure 10a: Contour plot of $\delta^{18} \mathrm{O}$ values in Brentwood region groundwater.

Figure 10b: Cross section of $\delta^{18} \mathrm{O}$ values in Brentwood region groundwater.

Figure 11: Plot of nitrate vs. $\delta^{18} \mathrm{O}$ in Brentwood region groundwater.

Figure 12: Piper Plot of Brentwood region groundwater chemistry.

Figure 13: Plot of EC vs. $\delta^{18} \mathrm{O}$ in Brentwood region groundwater.

Figure 14: Plot of $\mathrm{Cl}$ vs. $\delta^{18} \mathrm{O}$ in Brentwood region groundwater.

Figure 15: Plot of DO vs. ${ }^{14} \mathrm{C}$ ages in Brentwood region groundwater.

Figure 16: Diagram outlining method of groundwater flow rate calculation in Brentwood region groundwater.

Figure 17: Plot of applied irrigation water vs. time in Brentwood region groundwater.

Figure 18: Plot of groundwater pumped vs. time in Brentwood region groundwater.

Figure 19: Plot of projected safe yields vs. population in Brentwood region groundwater.

Figure 20a: Contour map of ${ }^{14} \mathrm{C}$ ages in Brentwood region groundwater.

Figure 20b: Cross section of ${ }^{14} \mathrm{C}$ ages in Brentwood region groundwater. 


\section{List of Tables}

Table 1: Characteristics of wells sampled in the Brentwood region.

Table 2: Chemical and isotopic data for groundwaters in the Brentwood region.

Table 3: Water quality standards and observation in the Brentwood region.

Table 4: Groundwater flow rates in the Brentwood region.

Table 5: Groundwater model components in the Brentwood region. 


\section{Executive Summary}

Under contract with the City of Brentwood and auxiliary support by the East Contra Costa Irrigation District (ECCID), a research assessment of the groundwater resources beneath the Brentwood region was conducted using isotope hydrology techniques. The isotope measurements have been used as a tracer and age indicator that details the source, migration paths, and migration rates of existing groundwater supplies at a fraction of the cost of traditional hydrogeological methods. The isotope results provide a quantitative framework in which to answer questions important to the City of Brentwood and the ECCID including:

1) What is the long-term and short-term sustainability of the groundwater resources relative to current urban growth projections?

- The amount of groundwater that can be pumped from the ground without depleting the resource is between 370 and 1430 acre-ft per year for a population of $\sim 70,000$ people. This quantity of groundwater represents only 3 to $11 \%$ of the water needed to meet the annual domestic demand. Current recharge to the Brentwood region groundwater basin area $\left(-27 \mathrm{mi}^{2}\right)$ exceeds the amount pumped. Simple model results indicate that the City of Brentwood uses about 3 times more groundwater than can be sustained within its current geographic extent. This local pumping depression accelerates the migration of high nitrate groundwater to the zones of pumping.

- Poor water quality, in particular the high nitrate concentrations, is predominantly a result of agricultural irrigation and fertilizer application historically practiced in this area. In the long-term ( $\geq 10$ years), much of the 372 to 1430 acre-ft of available groundwater will probably have excessive nitrate concentrations and water treatment will be necessary.

- Most of the groundwater recharged during the past $\sim 80$ years has been agricultural irrigation water. Retirement of agricultural land will eliminate most of the groundwater recharge, and therefore, the available groundwater supply will decrease as urban growth increases. Projected growth of the City of Brentwood will be predominantly in the recharge areas of the groundwater basin. Therefore, the 372 acre-ft per year water supply is probably more realistic than the 1430 acre-ft per year. 
2) How can the good water quality be maximized in groundwater wells under short and long-term groundwater use schemes?

- Reducing the rate of pumping from groundwater wells is the most effective way to prolong the life of good quality groundwater in the Brentwood region. Current pumping can be offset by well head treatment of nitrate contaminated wells that are functional but not in use, and treatment of deeper wells high in iron and manganese. Current demand on the active city wells (\#6, 7, and 8) are causing a significant water level drawdown exceeding $100 \mathrm{ft}$ below the surface. If this focused pumping with a large drawdown continues indefinitely, then unsafe nitrate levels could reach these well intakes within 10 to 15 years.

- Long-term strategies should include alternative water sources from inside and outside the groundwater basin. As urban growth continues, less groundwater will be available for pumping at safe-yields. Cost effective management strategies for groundwater in California today include artificial recharge projects. Such projects typically incorporate 1) engineered surface recharge of excess surface water supplies such as storm runoff or local streams, and/or 2) direct groundwater injection of the surface water and reclaimed waste water. The results of the ${ }^{14} \mathrm{C}$ analyses suggests that some areas of the groundwater basin have lateral continuity of aquifers that may be conducive to injected recharge, and its feasibility could be further explored.

- All future groundwater production in the Brentwood region should be evaluated on a groundwater basin scale. Groundwater produced in one part of the basin currently has an impact on other parts of the basin, a relation that will become more intimate with time. Any comprehensive groundwater management plan should incorporate regular diagnostic monitoring of groundwater for 1) regional water table levels measured twice a year on April 1 and October 1,2 ) regional Level $I I$ groundwater quality surveys every 1 to 5 years depending on the nature of groundwater use, and 3) a stable isotope survey once every ten years to monitor changes in sources and migration of the regional groundwater.

3) What underground areas exist within the Brentwood region that indicate untapped groundwater supplies that may provide plentiful, good quality water? 
- Of the shallower groundwater, only an eleven square mile area surrounded by the roads of Sellers, Bixler, Delta, and Balfour hosts groundwater that has for the most part been unaffected by agricultural recharge water. This area is dominated by clay-rich sediments that has prevented its infiltration. However, the poor permeability of the sediments suggests that aquifers with good yields ( 500 to $>1000$ gallons per minute) may not be common and well development may be limited.

- Focused recharge of pristine groundwater appears to occur on the west side of the Brentwood region in relation to Deer Creek Valley and Briones Valley. An example of a well penetrating this kind of aquifer is city well \#10. Although it is a deeper (300-400 feet below the surface) than most wells in this area, the age of the groundwater in this aquifer is much younger than ages observed at similar depths in other parts of the Brentwood region. This suggests that permeable aquifers may occur in the proximity to well \#10 and Deer Creek Valley.

- Most unexplored groundwater occurs below 300 feet in the Brentwood region. Various evidence suggest that plentiful and potable groundwater supplies are not common at depths greater than the current production levels in the Brentwood region. Based on well log records, Berkstresser (1973) indicated that groundwater potability does not exceed 400 feet below sea level in this region. Further evidence for this idea is found on the west side of the Brentwood region, where there is a lack of the surface geological exposures that are characteristic of the highyielding potable aquifers of the Central Valley of California and only thin alluvial deposits are present. Slow recharge and groundwater flow in the alluvial deposits of the Brentwood region allows more time for the groundwater to undergo natural chemical reactions that decreases the water quality, for instance, buildup of the iron and manganese typically observed in the deeper groundwater of Brentwood region.

- Although geologic exposures of the more productive-type aquifers do not appear on the west side of the Brentwood region, these aquifers may exist deeper in the subsurface east of the City of Brentwood. Productive aquifers may occur deeper than 400 feet below sea level, but their quality may exceed drinking water standards. If deeper aquifers exist east of the City of Brentwood, they are likely to be overlain by a confining layer and to be recharged slowly. 
- Currently, the groundwater aquifers on the northern part of the Brentwood region are productive and of reasonable quality. Shallower groundwater in adjacent areas, though, are observed to have elevated nitrate levels, and the sustainability of good water quality for the northern aquifers is probably limited. The vertical interconnectivity of the shallow and deeper aquifers cannot be ascertained at this time, but data suggest that they are not independent of each other. 


\section{Introduction}

The City of Brentwood is currently experiencing an approximate annual growth rate of $10 \%$ that will nearly triple the current population by the year 2005 . As a result, there will be a concomitant tripling of the water demand. Adequate water resources are a requirement, yet Brentwood's current and projected needs are superimposed on water shortages and degrading quality that are becoming chronic throughout California. Moreover water quality in the Brentwood production wells has progressively decreased overtime, such that 5 out of 7 of city wells have been taken off the drinking supply due to nitrate levels that exceed the Environmental Protection Agency's standards. Water planning is therefore essential, but a prudent approach must be based on new and accurate information.

The City of Brentwood and the East Contra Costa Irrigation District (ECCID) seek to assess and develop the remaining groundwater resources at their disposal. At this time both entities have sought innovative approaches to groundwater resource evaluation that incur less cost and yield more detailed results than traditional hydrologic assessments. At the request of the City of Brentwood-ECCD Liaison Committee, this research was proposed and funded under a contract by the City of Brentwood and auxiliary support by the ECCID to Lawrence Livermore National Laboratory. This report provides a research component for the AB 3030 Groundwater Management Options Report currently under revision by the respective agencies. This research utilizes analytical techniques that have been institutionalized in the scientific community for decades, but are rarely used in the commercial sector. Generation and integration of these data into a groundwater investigation is an innovative approach that has been developed in similar groundwater basins. Explanation of the fundamental concepts behind these analytical techniques is provided in Appendix 1.

Specific questions that have been formulated by the City of Brentwood and the ECCID regarding the future of groundwater in the area include: 1) What is the long-term 
and short-term sustainability of the groundwater resources relative to current urban growth projections? 2) How can good water quality be maximized in groundwater wells under short and long-term groundwater use schemes? 3) What underground areas exist within the Brentwood region that indicate untapped groundwater supplies that may provide plentiful, good quality water? These questions have been addressed using isotope measurements of oxygen, hydrogen, and carbon, which provide a means of identifying distinct groundwater source signatures and groundwater ages. These data were used to develop a quantitative mass balance model that was coupled with quantifiable elements of the groundwater system to elucidate the current state of the regional groundwater quality, quantity, aquifer permeability, and flow.

\section{Study Area}

Physiography - The Brentwood region study area (Fig. 1) has a semi-arid climate that is typical of the Central Valley of California, where annual precipitation occurs between late fall and late spring and the remainder of the year is hot and dry. The mean January temperature measured in Antioch is $6^{\circ} \mathrm{C}\left(42^{\circ} \mathrm{F}\right)$, while the mean July temperature is $23^{\circ} \mathrm{C}$ ( $74^{\circ} \mathrm{F}$; Welch, 1977). Yearly mean precipitation in this same area is approximately 13 inches (Welch, 1977). In the natural state, annual grasses and oak trees grew in this semiarid climate, but today usually occur only in the hilly regions of the Coast Range.

The Brentwood region incorporates a 17,000 acre area approximately defined by the boundaries of the East Contra Costa Irrigation District (ECCD; Fig. 1). The Brentwood region is located approximately 12 miles east-northeast of Mt. Diablo, 20 miles west of the City of Stockton, and less than 4 miles southeast of Antioch. The Brentwood region is bordered on the north by the town of Oakley, on the east by the Delta Islands defined by Rock and Indian Sloughs and Discovery Bay, and on the south and west sides by the hilly exposures of the eastern Coast Ranges. Most of the Brentwood region gently slopes northeastward toward the Sacramento-San Joaquin Delta 
with roughly 1 foot of elevation decrease for every 300 feet of lateral distance. Subdued hills occur in the northern part of the Brentwood region just south of Oakley, while sharper elevation increases border the region on the west and south of the area and represent exposures of Coast Range marine rocks.

A variety of soils occur in the Brentwood region (Fig. 2), but the dominant types are 1) clay loams, principally occurring in the western to northern parts of the area, and 2) clays that typically dominate in the eastern areas (Welch, 1977). The predominance of these two types are most likely related to the coarseness of the sedimentary deposits. Coarser-grained sediments are probably common in the subsurface on the western side of the Brentwood region, where streams flowing from the hills historically deposited coarse sediment loads where the topographic gradient flattened. In the eastern part of the region, finer grained sediments are more likely to occur due to close proximity to the flood plains of the San Joaquin River. Another soil type worth noting are the sandy soils that occur in the low-lying hills in the northern part of the region.

The most prominent natural surface drainage in the Brentwood region is the perennial drainage of Marsh Creek (Fig. 1), which flows from the south to the north through western Brentwood and is tributaried by ephemeral drainages of Sand, Deer, and Dry Creeks. All creeks drain an area of $\sim 100 \mathrm{mi}^{2}$ in the immediate Coast Range areas to the west and south of the Brentwood region. Average flows in Marsh Creek are estimated at 5 to 100 cubic feet per second (cfs), although during maximum flood stages, flows may exceed $4700 \mathrm{cfs}$ (Nolte and Assoc., 1992). Our field observations of Marsh Creek in August of 1994 indicate that the flow was $~ 5 \mathrm{cfs}$ and based on results below, comprised predominantly agricultural water returns. On the eastern side of the Brentwood region, the Old River is a western arm of the San Joaquin River whose influence on groundwater recharge is discussed below. 
Land Use - The ECCID has a 50,000 acre-ft water right to the Delta surface water, and in ca. 1913 built an east-west canal (Fig. 1) for water delivery to farmers who up to that time were dry farming (probably grains) the Brentwood region. Diversion of surface water is from Old River via Indian Slough (Fig.1). Diversion did not peak until around 1960 when nearly all irrigation needs of the 17,000 acre area of the Brentwood region was serviced by the canal water. Orchards and row crops dominated the landscape up until at least the mid 1950's. Two decades later many farms were subdivided into smaller ranchtype farms. With this ruralization of the land, the population density only modestly increased. Groundwater well drilling logs record this period of subdivision, where dramatic increases occurred in the number of private domestic wells drilled between $\sim 1970$ and 1990 with a total of over 550 well logs on record.

The ECCID records indicate that between 1950 and 1961 the population was close to 5000 people. Between 1962 and 1968 the population increased to 6000. The population is reported at 8000 in 1968 , and for this report, that figure has been extended through 1985. An average population of 10,000 is estimated between 1986 to 1994. The City of Brentwood has entered into a state of urban and suburbanization with a projected growth rate of $10 \%$ between now and 2005 that will add another 21,000 people to the existing population. Build-out population limits are tentatively projected at 70,000 to 80,000 people by the year 2020 (CCWD, 1993).

Water Resources - Two main sources of water for municipal (domestic), industrial, and agricultural use are available in the Brentwood region: 1) Delta water, and 2) groundwater. By an agreement with the Central Valley Project, the Contra Costa Water District holds Delta surface water rights (195,000 acre-ft; CCWD, 1993) and services areas north of the Brentwood region. The Byron Bethany Irrigation District, located to the south, and the ECCID both hold riparian rights to Delta water also and historically have supplied irrigation needs to the area farmers. 
The City of Brentwood has used large capacity municipal pumps to supply incorporated areas with drinking and industrial water. In recent years groundwater pumped from these wells have increased in their dissolved nitrate content (Fig. 3) and in many cases have exceeded safe drinking water limits that forced the shutdown of some wells.

Private domestic wells are very common in the Brentwood region and comprise the majority of groundwater sampling sites investigated in this report. Wells commonly are small diameter casing with single perforation construction equipped with low horsepower ( $<1$ to $5 \mathrm{hp}$ ) pump motors. These wells usually supply general household needs as well as lawn irrigation in all the unincorporated areas of this region.

\section{Hydrogeology}

Regional Geology - The Central Valley of California is a large intermontane basin, created over the past 65 million years by convergent tectonic forces, that contains a large potable groundwater resource in its upper most $2700 \mathrm{ft}$ (Page, 1986). The Central Valley is bounded on the west by the Coast Ranges, comprising tectonically upthrusted marine sediments that dip eastward and underlie the valley. To the east, the valley is bordered by the granitic and metamorphic rocks of the Sierra Nevada. Deposited within this Central Valley trough are $13 \mathrm{~km}$ of ancient deposits called the Great Valley Group that comprise ocean sediments laid down as recently as 5 million years ago (Redwine, 1972; Page, 1986). These deposits typically contain saline water (Page, 1986).

Continental surface deposits laid down by rivers, streams, and lakes have accumulated to the present time and reach up to $3000 \mathrm{ft}$ in some places in the Valley. The continental deposits usually are unconsolidated and consist of gravels, sands, silts, and clays derived from erosion of the Coast Ranges and the Sierra Nevada.

The Brentwood region is sandwiched between the prominent geologic features of Mt. Diablo to the southwest and the Sacramento-San Joaquin Delta to the northeast. Mt. 
Diablo was formed during the late Miocene ( $\sim 5$ million years ago) to recent geologic times (Colburn, 1961) and may still be actively rising (J. R. Unruh, Wm Lettis \& Assoc., pers. comm., 1994). The Sacramento-San Joaquin Delta has been a locus of continuous sedimentary deposition for $>66$ million years, forming cycles of deeply incised channels filled with marine sediments that today host abundant plays of oil and gas. These channel-fill deposits are exposed on the western and southwestern edges of the Brentwood region and are Eocene in age (37-58 million years old). Freshwater deposits have been laid down in the Sacramento-San Joaquin Delta for an estimated 1 million years, but multiple incursions of saline water have undoubtedly occurred with fluctuating sea levels in the geologic past. Today, brackish groundwater is observed at shallow depths in the Delta.

The stratigraphy of the fluvial deposits of the northern San Joaquin Valley and east of the Sacramento-San Joaquin Delta has been characterized by previous workers (Davis, 1959; Department of Water Resources, 1967) and is review briefly here and summarized in Fig. 4. In Miocene times (5-24 million years ago), deposition of valley sediments transitioned from marine to continental-type, culminating in deposition in massive sandstones and shales of the San Pablo group on the western side of the valley. Contemporaneous continental deposits on the east side of the Central Valley are known as the Mehrten Formation comprising silts, sands, and gravels of volcanic origin. The San Pablo group rocks do not represent viable groundwater aquifers.

The San Pablo Group are overlain by Plio-Pleistocene (1-5 million years old) sediments on the west side of the valley and are known as the Tulare Formation, a regionally important geologic layer. Plio-Pleistocene equivalent deposits on the east side of the valley are known as the Laguna Formation. Both Formations range over 1000 feet thick in places and host productive freshwater aquifers of sand to gravel size sediments. South, in the San Joaquin Valley the Plio-Pleistocene sediments host a several hundred foot thick clay layer that acts as a regional confinement to deep, freshwater aquifers. The 
thick clay layer is known as the Corcoran Clay and has been traced from 25 miles southeast of the Brentwood region to the southern edge of the San Joaquin Valley (Frink and Kues, 1954).

Sediments that overlie the Plio-Pleistocene deposits are Pleistocene to modern in age, comprising alluvial fan deposits that were eroded from the western Sierras and the eastern Coast Ranges, as well as flood basin deposits that are usually thickest in the central part of the valley. Stream sediments are also part of these more recent sediments, and along with alluvial fan deposits typically range only up to 150 feet thick but can host productive freshwater aquifers. The Pleistocene to modern deposits occur in the Brentwood region and are related to shallow alluvial deposits eroded from the Eocene and older rocks of the western hills as well as local stream channels.

Part of the impetus for this research is the exploration of deeper groundwater resources in the Brentwood region. In essence this requires a determination of whether the thicker productive aquifers of the Plio-Pleistocene deposits observed in other parts of the valley occur below the current depths of groundwater use in Brentwood. The answer to this question ultimately lies in understanding the tectonic development of Mt. Diablo and its influence on sedimentary deposition in the Brentwood region and the SacramentoSan Joaquin Delta to the northeast. Mt. Diablo underwent much of its uplift during the Plio-Pleistocene time, although some previous tectonic activity caused regional depostional hiatuses in the Oligiocene to mid-Miocene period (Colburn, 1961). Figure 5 is a generalized geologic map that shows surface evidence for the sedimentation patterns in the Brentwood region over the last 50 million years. The exposed center of Mt. Diablo is composed of Jurassic ( $\geq 140$ million years old) marine rocks that have been uplifted and thrusted over younger Cretaceous (66 to 100 million years old) marine rocks on its northeast side. The continuous uplift and subsequent erosion has left a large exposure of Cretaceous rocks northeast and southeast of Mt. Diablo. Deposition of sedimentary material in the Delta region during Mt. Diablo uplift has been continuous to the present in 
low elevation areas of near-flat topography that are predominantly submergent below water, whereas higher elevation areas of sloping topography were predominantly being eroded. These relationships are best seen in the sedimentary sequence exposed on the north and northeast side of Mt. Diablo (Antioch and Pittsburg area) where sedimentary beds range sequentially from Cretaceous to Plio-Pleistocene sediments. Likewise, just west-northwest of Byron the same stratigraphic sequence is observed. The exposure of the sequential sedimentary beds represents localized sedimentary sub-basins in this region where continuous deposition occurred during the Mt. Diablo uplift. In contrast, though, rock exposures on the west side of the Brentwood region lack sedimentary sequences like those observed to the north and south. The exposures west of the Brentwood region show Eocene-aged sediments of the hills directly underlaying recent alluvial sediments in the valley floor, and the Miocene-aged and Plio-Pleistocene-aged sediments are absent. This indicates that the western area of the Brentwood region was not submergent beneath water during the Miocene and the Plio-Pleistocene and lacks those principal geologic formations. Therefore, the productive freshwater aquifers seen in the Plio-Pleistocene formations in other parts of the Central Valley are lacking at least in the western parts of the Brentwood region and only the shallow modern alluvial sediments are present. In addition, if the Plio-Pleistocene formations occur further east below the Brentwood region, they may not be as thick as their equivalents seen in type localities in other places of the Central eroded alley.

Groundwater - Water table levels in the groundwater of the Brentwood region (Fig. 6) maintain a regular west to east downward slope in the southern part of the Brentwood region and a southwest to northeast downward slope in the northern part. Available records, predominately at the $\mathrm{ECCD}$, show that this water table level pattern is consistent from one year to the next. The inferred groundwater flow direction generally follows the hydrologic gradient which averages $\sim 0.003$. 
Regional groundwater quality in the Brentwood region has been investigated by Sorenson (1981) who determined that in general electrical conductivities of groundwater typically exceed 1000 microsiemens per $\mathrm{cm}(\mu \mathrm{S} / \mathrm{cm})$. These groundwaters are of a $\mathrm{CaNa}-\mathrm{HCO}_{3} \mathrm{Cl}$ type with pockets having chloride $(100-250 \mathrm{mg} / \mathrm{L})$, nitrate $(>20 \mathrm{mg} / \mathrm{L})$, and boron (1-2 $\mathrm{mg} / \mathrm{L})$ levels that are moderately to abnormally high for Central Valley groundwater. Aqueous chemical data presented in this report are consistent with those of Sorenson (1981) (see below). Glass (1981) found similar groundwater chemistry, but more variable, in wells completed in Eocene rocks and alluvial pockets southwest of the Brentwood region.

Berkstresser (1973) mapped the base of potable groundwater in the northern Central Valley that included the Brentwood region. The potable water base was defined as the depth where groundwater reaches or exceeds $3000 \mu \mathrm{S} / \mathrm{cm}$, that is the drinking water limit. Berkstresser (1973) determined on limited data that the base of freshwater was pervasively 400 feet below séa level in the Brentwood region. This is equivalent to approximately 400 to 550 feet below the surface (fbs). Almost all groundwater in the Brentwood region today is pumped from shallower depths ( $<300 \mathrm{fbs}$ ). Berkstresser (1973) also showed that the base of the potable groundwater occurs deeper to the north and southeast of the Brentwood region and corresponds to down-dip projections of the Plio-Pleistocene formations that are exposed south and north of the Brentwood region.

Wells completed in the upper 300-400 feet of the Brentwood region typically have yields that range from $<1$ to 2000 gallons per minute (gpm). High capacity pumping is currently limited to the City of Brentwood and the ECCID whose annual combined withdrawal is much less than the regional safe yield (see Henneman, 1990; Davisson and Campbell, 1994) 


\section{Results}

Well Logs - An investigation of driller well logs was initiated in the Brentwood region during the earlier stages of this research. All well logs used are drilling records submitted to the state as required by law and stored at the Department of Water Resources in Sacramento. A total of 648 well logs were obtained of which 577 are of domestic, low capacity construction. Each well location was plotted relative to its township, range and section in Fig. 7a and Fig. 7b, where respectively the number of well occurrences per section and their average perforation depths have been contoured. As can be seen, well occurrences are concentrated in the northern and central part of the Brentwood region associated with the City of Brentwood and the State Hwy. 4 corridor (Fig. 7a). The depth of average perforation for the wells in the Brentwood region deepens from west to east (Fig. 7b), where wells west of the City of Brentwood predominantly are $<100 \mathrm{fbs}$. Well perforations in areas east of the City generally average between 100 and $150 \mathrm{fbs}$, but rapidly progress toward deeper depths close to the Old River. The contour pattern of average perforation depths on the south side of the Brentwood region (Fig. $7 \mathrm{~b}$ ) indicates that wells are utilizing permeable layers that deepen from west to east and suggests old buried stream channels that contain coarse sedimentary material. Wells with perforation intervals completed solely at depths $\geq 200 \mathrm{fbs}$ generally only occur to the north and east of the City of Brentwood and represent $\sim 8 \%$ of the total well logs. Almost every well is drilled above 500 fbs.

Sampling Sites and Methods - Over 90 water samples were collected during this study for chemical and isotopic analyses (see Tables 1 and 2). A collection of 12 samples from various locations of the ECCD irrigation canals was carried out early in the study to characterize the agricultural water recharge component to the groundwater system in the Brentwood region. The remaining 80 samples represent groundwater in the Brentwood region of which two-thirds of them have well log information. Most samples are from 
private domestic wells that were according to the following procedure: 1) select a well from the well log records for optimal location and depth, 2) accurately locate the well described in a specific well $\log , 3$ ) inspect the well for appropriate construction and sampling access, 4) ask permission to sample the well from the well owner during a single interview, and 5) sample the well. Domestic well construction is similar throughout the Brentwood region and consists of 6 to 10 inch stainless steel or PVC pipe well casing equipped with either a submersible or immersible-type pump of low horsepower (usually $<1$ to $5 \mathrm{hp}$ ). The discharge pipe almost always was connected to a pressurized holding tank varying in volume from 20 to 200 gallons. Water samples were either taken from a spicket connected directly to the holding tank or in line to the household plumbing. Rarely were sampling points located between the pump and the holding tank. Since the pressurized holding tank is closed to the atmosphere and daily household use usually cycled the water through the tank daily, sample integrity was not compromised. Care was always taken to make sure all samples were collected at a location along the flow path before passing through any softeners or reverse osmosis water purifying systems.

Municipal wells that were operated by the City of Brentwood were accessed and sampled with the help of the City Public Works Dept. staff. Also municipal wells maintained for the Discovery Bay community in the east were sampled. Municipal wells are of high capacity (500-2000 gpm) with large diameter casings (12 to 18 inches) and submersible and immersible pumps. Samples were usually collected at water quality taps along the discharge pipe adjacent to the pump head. Well pumps were usually run for at least 5 minutes before the sample was collected.

Agricultural wells sampled were mostly those operated by the ECCID and are also of large capacity, wide diameter casing and equipped with immersible pumps. The ECCID wells typically are older wells with multiple perforation and shallow construction ( 100 to $200 \mathrm{fbs})$. Water discharged directly from the pump into the irrigation canals via 
a large pipe. Flows were usually in excess of $500 \mathrm{gpm}$ and samples were collected directly from the water stream.

Field data consists of $\mathrm{pH}$, conductivity, alkalinity, temperature, dissolved nitrate and dissolved oxygen measurements. The $\mathrm{pH}$, conductivity, and temperature were measured with standard electronic instruments and calibrated against known standards when possible. The alkalinity measurements were made with standardized field titration kits. Nitrate measurements were conducted with commercial color indicator paper strips. Dissolved oxygen (DO) were made with commercial colorimeter kits.

Samples for chemical analyses were collected in clean 30 to 125 milliliter (ml) plastic bottles and refrigerated without filtering or acidification. This protocol does not follow Environmental Protection Agency (EPA) certified methods for some of the elements analyzed. This is further discussed below. Samples collected for stable isotopes of ${ }^{18} \mathrm{O}$ and deuterium were collected untreated in 15 to $50 \mathrm{ml}$ glass bottles with a polyseal cap (plastic conical insert inside cap) to prevent evaporation. Samples for ${ }^{13} \mathrm{C}$ and ${ }^{14} \mathrm{C}$ were collected in 50 to $125 \mathrm{ml}$ glass bottles with either a polyseal cap or a teflonlined rubber septa cap to prevent exchange with atmospheric $\mathrm{CO}_{2}$. Approximately 4 drops of a saturated solution of mercuric chloride were added to the sample to kill all microbial life in the water sample. The sample was collected in laminar flow conditions to prevent entrapment of atmospheric $\mathrm{CO}_{2}$. All ${ }^{13} \mathrm{C}$ and ${ }^{14} \mathrm{C}$ samples were kept refrigerated.

Field Data - Most wells were determined for $\mathrm{pH}$, conductivity, temperature and nitrate concentration in the field. Alkalinity and DO measurements were conducted when possible but are limited due to test kit availability and need. The $\mathrm{pH}$ levels in the Brentwood region groundwater show normal, near-neutral values (6.5 to 7.5) typically observed in potable groundwaters (Hem, 1985). The values are generally very uniform except for a low value seen in groundwater that occurs in Eocene rocks (BR-43-see Table 
2), or higher values observed in deeper wells of the eastern part of the region, particularly in the Discovery Bay wells.

The electrical conductivity of a water is a relative measurement of its dissolved salt concentration. Recommended safe drinking water limits have been set by the EPA at $3000 \mu \mathrm{S} / \mathrm{cm}$. Groundwater in the Brentwood region is usually between 1000 and 2000 $\mu \mathrm{S} / \mathrm{cm}$. Lower conductivity groundwater $(<1000 \mu \mathrm{S} / \mathrm{cm})$ occurs in limited areas of the eastern part of the region, whereas higher values $(>1000 \mu \mathrm{S} / \mathrm{cm})$ are pervasive in the western to central areas.

Dissolved nitrate $\left(\mathrm{NO}_{3}\right)$ in the groundwater has a primary drinking water limit of $45 \mathrm{mg} / \mathrm{L}$ set and enforced by the EPA. $\mathrm{NO}_{3}$ usually does not naturally occur in groundwater at significant levels. High $\mathrm{NO}_{3}$ concentrations have been observed in many groundwaters worldwide (e.g. Freeze and Cherry, 1979) and are attributable to anthropogenic (since human activities) sources such as agricultural fertilizers, leaky septic tanks, and herd animal feed lots. By far, agricultural fertilizers represent the most abundant source of dissolved $\mathrm{NO}_{3}$ in California groundwaters today (Davisson and Criss, 1993).

The field $\mathrm{NO}_{3}$ concentrations have an analytical uncertainty of $\pm 20 \%$ and are not EPA certified measurements. Field concentrations of $\mathrm{NO}_{3}$ range from 0 to $\sim 100 \mathrm{mg} / \mathrm{L}$ as nitrate, and approximately $40 \%$ of all wells measured exceed the EPA primary drinking water standard. It is assumed that pre-anthropogenic $\mathrm{NO}_{3}$ concentrations are $<5 \mathrm{mg} / \mathrm{L}$ for this region. The $\mathrm{NO}_{3}$ concentrations show a regular distribution in map view and crosssection view in the Brentwood region (Fig. 8a and 8b), with the highest concentrations observed in groundwater along a broad zone stretching from the northwest to the southeast of the City of Brentwood. The $\mathrm{NO}_{3}$ concentrations approach zero concentration toward the eastern areas and the western boundaries of the bordering hills. In cross-section the $\mathrm{NO}_{3}$ concentration approaches $100 \mathrm{mg} / \mathrm{L}$ at shallow depths $(<100$ fbs), but decreases with increasing depth. In three wells north, east and south of the City 
of Brentwood, groundwater has non-zero $\mathrm{NO}_{3}$ values greater than $250 \mathrm{ft}$ below the surface. The western side of the Brentwood region has the deepest penetration of high $\mathrm{NO}_{3}$ groundwater. On average, the depth of $50 \mathrm{mg} / \mathrm{L} \mathrm{NO} 3$ groundwater is observed between 100 and 150 fbs. Note that neither the field test kits nor the $\mathrm{lab} \mathrm{NO}_{3}$ results can be certified to EPA standards. On the other hand, the field and lab results show the relative amounts of dissolved $\mathrm{NO}_{3}$ and should be treated semi-quantitatively. The $\mathrm{NO}_{3}$ results are also consistent with recent $\mathrm{NO}_{3}$ increases in City of Brentwood groundwater (Fig. 3) that have forced shutdown of many municipal wells.

Temperatures were documented in well waters and range between 16.7 and $27^{\circ} \mathrm{C}$. Normally groundwater temperatures will increase with increasing depth of the sample. However most samples were collected from pressurized holding tanks which thermally equilibrate during the day and much of the aquifer temperature is lost. Since most of the sample temperatures are within a normal groundwater temperature range some residual aquifer temperatures are undoubtedly present indicating that water is not stored in the holding tanks for a long period of time.

At the observed $\mathrm{pH}$ range for these potable groundwaters, alkalinity is a general measurement of the dissolved inorganic carbon concentration. Field alkalinities in the Brentwood region groundwaters narrowly range from 200 to $400 \mathrm{mg} / \mathrm{L}$ as $\mathrm{HCO}_{3}$ and are normal groundwater concentrations. The variations in alkalinity do not follow trends in the other field data. Defining the sources of dissolved carbon is important to groundwater age dating and is discussed below.

The concentration of dissolved oxygen (DO) in surface water is typically between 8 and $13 \mathrm{mg} / \mathrm{L}$ and is in near equilibrium with the atmospheric oxygen (Hem, 1985). Natural groundwaters range from $0-13 \mathrm{mg} / \mathrm{L}$, where low DO usually indicates either older groundwaters or water that has experienced significant anoxic (oxygen deficient) subsurface conditions. Brentwood region groundwater varies in DO from 0.5 to $12 \mathrm{mg} / \mathrm{L}$ and show a decreasing concentration from the western areas toward the eastern areas. 
Few water table levels were collected due to failure of our depth indicator equipment. Well head access to water level measurements is common in most domestic wells, particular those of recent construction (Table 1). Some water levels were taken with a sounding device loaned by the City of Brentwood, but the data are not regionally extensive. Regular water level surveys in the Brentwood region would be valuable to basin management and is discussed below.

Stable Isotope Data and Groundwater Sources - The terminology, systematic behavior, and utility of stable isotopes in groundwater resource evaluations are discussed in Appendix 1 . The ${ }^{18} \mathrm{O}$, deuterium, and ${ }^{13} \mathrm{C}$ concentrations in the groundwater are measured as ratios of $18 \mathrm{O} / 16 \mathrm{O}, \mathrm{D} / \mathrm{H}$, and ${ }^{13} \mathrm{C} /{ }^{12} \mathrm{C}$, respectively. These ratios are then normalized to a standard (seawater for ${ }^{18} \mathrm{O}$ and deuterium, and marine calcite for ${ }^{13} \mathrm{C}$ ) and reported in a $\delta$ notation (pronounced "del"), where $\delta^{18} \mathrm{O}, \delta \mathrm{D}$, and $\delta^{13} \mathrm{C}$ are the concentration as parts per thousand or per mil (symbol used here is "\%o"). The $\delta^{13} \mathrm{C}$ values of the Brentwood region groundwaters are presented and discussed in the radiocarbon section below.

The $\delta^{18} \mathrm{O}$ values of the groundwater sampled in the Brentwood region indicate two sources of groundwater originating as 1) pristine groundwater recharged by local rain water, and 2) agricultural irrigation water that has recharged during the past $\sim 80$ years. Local rain water can be identified by a plot of $\delta \mathrm{D}$ and $\delta^{18} \mathrm{O}$ values (Fig. 9). Precipitation throughout the world shows a systematic linear behavior on such a plot and define a unique linear regression of $\delta \mathrm{D}=8 \delta^{18} \mathrm{O}+10$ and is known as the global meteoric water line (GMWL; Craig, 1961). This line provides a graphical tool for determining if a groundwater is recharged directly from a precipitation source, where in such cases the isotope abundance of the water is preserved. Groundwater that has no detectable $\mathrm{NO}_{3}$ concentration has $\delta 180$ values between -6.5 to $-7.0 \% o$ and $\delta \mathrm{D}$ values between -45 and $-54 \%$ and define data that lies close to the GMWL (Fig. 9). Local meteoric waters in 
various global regions can define slightly different linear regressions on a $\delta \mathrm{D}-\delta^{18} \mathrm{O}$ plot, resulting in a local meteoric water line, where the slopes can vary between 7.5 and 8.5 and $y$-intercepts between 0 and 15 (Fontes, 1980). The GMWL is a global average of all observed precipitation. In the case of the Brentwood region, a local meteoric water line may exist that is shifted slightly downward on the $\delta \mathrm{D}-\delta^{18} \mathrm{O}$ plot and this would explain why the highest isotope values sit slightly to the right of the GMWL. By virtue of their proximity to the GMWL, negligible $\mathrm{NO}_{3}$ concentrations, and radiocarbon ages presented below, the highest $\delta^{18} \mathrm{O}$ and $\delta \mathrm{D}$ values define groundwater derived from local rain water recharge. These groundwaters are observed at the western edge of the Brentwood region as well as down-gradient on the eastern edge (Fig. 10a and 10b). In addition, these groundwater types are observed at deeper depths in the basin, typically $>250 \mathrm{fbs}$ (Table 2).

The lower the $\delta^{18} \mathrm{O}$ and $\delta \mathrm{D}$ values observed in the Brentwood region groundwater, the progressively further they plot from the GMWL, indicating mixing of a non-pristine, evaporated meteoric source. Evaporating surface water that originates as rain or snow shifts to the right of the GMWL as evaporation progresses (Craig et al., 1963). Agricultural irrigation water is predominantly imported to the Brentwood region from a San Joaquin River source that originates as Sierra Nevada precipitation. The $\delta^{18} \mathrm{O}$ value of precipitation in the Sierra Nevada is more negative than the local rain water in the Brentwood region due to orographic rain-out effects that deplete the storm.tracks of $18 \mathrm{O}$ and deuterium across California (Ingraham and Taylor, 1991). Earlier isotope results from Phase I of this study showed that the canal water pumped from Indian Slough by the ECCID was around $-9.2 \%$ in $\delta^{18} \mathrm{O}$, and due to progressive evaporation along the canal flowpath, the water increases to $-8.5 \%$. As seen in Fig. 9, the irrigation water lies further to the right of the GMWL than the pristine waters indicating evaporation from its original parent precipitation source at approximately $-12 \%$ in $\delta^{18} \mathrm{O}$, a value consistent with Sierran precipitation. As can be seen in Figs $10 \mathrm{a}$ and $10 \mathrm{~b}$, these lower $\delta^{18} \mathrm{O}$ values 
predominate over much of the Brentwood region, and like the $\mathrm{NO}_{3}$ concentrations, they have a mean penetration depth between 100 and $150 \mathrm{fbs}$. These low $\delta^{18} \mathrm{O}$ groundwaters mix with the pristine groundwater as evident from the linear mixing line defined in Fig. 9. An inverse correlation also exists between the measured $\mathrm{NO}_{3}$ concentration and the $\delta^{18} \mathrm{O}$ value of the groundwater (Fig. 11), showing that the recharged agricultural water is the source of most of the high $\mathrm{NO}_{3}$ in the groundwater supply.

Radiocarbon Data and Groundwater Ages - Groundwater derived from natural precipitation in the Brentwood region was recharged before agricultural development of the land (pre-1900). Determining the general age of natural groundwater would provide some indication of the its pre-historical rate of recharge and flow. Such information is important in establishing 1) the annual recharge rates of precipitation, 2) the difference between modern (i.e. agricultural) and natural recharge rates, and in some cases 3) the mechanism of recharge into individual aquifers and 4) their interconnectivity. Relating the ages of groundwater to geologic deposits in the basin may also help determine the extent of deeper, potable groundwater resources.

Groundwater ages have been characterized in this study by radiocarbon methods. Radiocarbon $\left({ }^{14} \mathrm{C}\right)$ measurements of groundwater have been widely used for tracing groundwater flowpaths and determining groundwater ages (see Taylor et al, 1990). The ${ }^{14} \mathrm{C}$ in groundwater is natural and is derived from atmospheric $\mathrm{CO}_{2}$, which dissolves in recharging groundwater as bicarbonate during plant root respiration of $\mathrm{CO}_{2}$ in the soil zone (see Appendix 1). The ${ }^{14} \mathrm{C}$ is radioactive and decays at a constant rate $\left({ }^{14} \mathrm{C}\right.$ half life $=5730$ years; Walker et al., 1989). Ideally, the groundwater age is proportional to the natural $\log$ of the ratio of dissolved ${ }^{14} \mathrm{C}$ to atmospheric ${ }^{14} \mathrm{C}$.

The ${ }^{14} \mathrm{C}$ concentrations are reported as a percent value relative to the ${ }^{14} \mathrm{C}$ of 1950 atmospheric $\mathrm{CO}_{2}$, or percent modern carbon (pmc). Groundwater ${ }^{14} \mathrm{C}$ in the Brentwood region varies from 20 to 103 pmc. Most values fall between 50 and 100 pmc. Values 
$>100$ pmc represent incorporation of post late-1950's atmospheric $\mathrm{CO}_{2}$ that is elevated in ${ }^{14} \mathrm{C}$ due to artificial injection from surface testing of nuclear weapons. Apparent ages calculated from the pmc values range between modern and 12,900 years. These ages represent the maximum possible age derived from the pmc values and were calculated assuming recharge ${ }^{14} \mathrm{C}$ concentrations were $100 \mathrm{pmc}$.

Minor decreases in the dissolved ${ }^{14} \mathrm{C}$ concentrations of recharging groundwater commonly occur. These variations are caused by dissolution of soil zone $\mathrm{CaCO}_{3}$, which typically has very little ${ }^{14} \mathrm{C}$. Because dissolution of "dead" $\mathrm{CaCO}_{3}$ does not add ${ }^{14} \mathrm{C}$ to the groundwater, the amount of dissolved ${ }^{14} \mathrm{C}$ decreases relative to its total dissolved carbon concentration. Therefore, the ${ }^{14} \mathrm{C}$ concentration of recently recharged groundwater usually is less than atmospheric concentrations, even though the groundwater may only be modern in age. Vogel (1967) recognized that modern-aged groundwater typically has ${ }^{14} \mathrm{C}$ concentrations approximately $85 \% \pm 5 \%$ of atmosphere. Therefore, Vogel (1967) suggests that when deriving an age from the ${ }^{14} \mathrm{C}$ concentration of an older groundwater, the measured ${ }^{14} \mathrm{C}$ should be compared to a ${ }^{14} \mathrm{C}$ concentration $\sim 85 \%$ of atmosphere.

Sample BR-28 provides evidence for the incorporation of $\mathrm{CaCO}_{3}$ into the dissolved carbon during recharge in the Brentwood region. BR-28 is $100 \%$ agricultural recharge water according to its $\delta^{18} \mathrm{O}$ value, but its ${ }^{14} \mathrm{C}$ value is only $86 \mathrm{pmc}$. Since agricultural irrigation is $<80$ years old, $B R-28$ cannot be as old as its ${ }^{14} \mathrm{C}$ value indicates (i.e. 1250 years old). Therefore, $\mathrm{BR}-28$ has incorporated ${ }^{14} \mathrm{C}$-depleted $\mathrm{CaCO}_{3}$. Furthermore, the $\mathrm{CaCO}_{3}$ was incorporated and the groundwater recharged before the late 1950 's, since more elevated ${ }^{14} \mathrm{C}$ concentrations would be expected like those seen in samples $B R-17, B R-19$, and $B R-33$. It is interesting to note that the ${ }^{14} \mathrm{C}$ value of $B R-28$ is similar to that predicted by Vogel (1967) for modern recharge groundwater.

We can apply a model correction to the ${ }^{14} \mathrm{C}$ age calculation for the Brentwood region groundwater by normalizing the measured ${ }^{14} \mathrm{C}$ pmc values of each sample to 86 
pmc instead of $100 \mathrm{pmc}$ as was used for the apparent ${ }^{14} \mathrm{C}$ ages above. The model corrected ages yield groundwater ages that range from modern to 11,800 years. These ages are slightly younger and are a closer representation of the "true" age of the groundwater.

The $\delta^{13} \mathrm{C}$ value of dissolved inorganic carbon (DIC) in groundwater is also controlled by plant respired $\mathrm{CO}_{2}$ and soil $\mathrm{CaCO}_{3}$. The $\delta^{13} \mathrm{C}$ value of plant respired $\mathrm{CO}_{2}$ is typically around $-25 \%$ for $\mathrm{C}_{3}$ plants (Calvin cycle), which are the most abundant type in California (Teeri and Stowe, 1976). Groundwater DIC in equilibrium with soil $\mathrm{CO}_{2}$ at $\mathrm{pH}$ values between 7.0 and 9.0 are around 8 to $9 \%$ higher in $\delta^{13} \mathrm{C}$ than plant respired $\mathrm{CO}_{2}$. This is due to natural partitioning of the ${ }^{13} \mathrm{C}$ isotope between two carbon phases in chemical equilibrium (Mook, 1980). At normal temperatures, the ${ }^{13} \mathrm{C}$ is preferentially concentrated in the dissolved carbon relative to the soil $\mathrm{CO}_{2}$. Therefore, groundwater DIC is expected to average around $-16.5 \%$ when in open communication with plant respired soil $\mathrm{CO}_{2}$. Soil $\mathrm{CaCO}_{3}$ typically has a much higher $\delta^{13} \mathrm{C}$ value that commonly falls in the range of $0 \%$. When soil $\mathrm{CO}_{2}$ is initially dissolved in infiltrating groundwater it reacts with the soil $\mathrm{CaCO}_{3}$ to form DIC, i.e. bicarbonate. This causes the $\delta^{13} \mathrm{C}$ value of the DIC to be temporarily shifted higher than $-16.5 \%$. If the DIC is in open communication with the soil $\mathrm{CO}_{2}$ at this point, then its $\delta^{13} \mathrm{C}$ value will return to $-16.5 \%$. If the DIC is not in open communication with the soil $\mathrm{CO}_{2}$, then its $\delta^{13} \mathrm{C}$ value will remain higher then $-16.5 \%$.

The ${ }^{13} \mathrm{C}$ values of groundwaters in the Brentwood region range from -16.3 to $-9.7 \%$. The latter value (BR-49) is derived from a groundwater sample suspected to be contaminated with septic effluent, as its high $\mathrm{NO}_{3}$ concentration does not correlate with its high $\delta^{18} \mathrm{O}$ value. Nevertheless, ignoring the highest $\delta^{13} \mathrm{C}$ value (BR-49), it is observed that the highest $\delta^{13} \mathrm{C}$ values are around $-11.5 \%$ o (e.g. BR-62 and BR-70-1). The $\delta^{13} \mathrm{C}$ values of pristine groundwaters $\left(\delta^{18} \mathrm{O}=-6.5\right.$ to $-7.0 \%$ ) vary over the entire $\delta^{13} \mathrm{C}$ range, where groundwaters associated with agricultural recharge tend to be somewhat 
lower $\left(\delta^{13} \mathrm{C} \sim-15.0 \%\right.$ ). These trends can be interpreted to represent different degrees of open communication between DIC and soil $\mathrm{CO}_{2}$ after dissolution of soil $\mathrm{CaCO}_{3}$. The lower the $\delta^{13} \mathrm{C}$ value, the more communication the DIC has had with the soil $\mathrm{CO}_{2}$, where higher $\delta^{13} \mathrm{C}$ values indicate less communication. In the pristine groundwaters, the shift in $\delta^{13} \mathrm{C}$ values from $-16.5 \%$ to $-11.5 \%$ represents $30 \%$ addition of carbon from soil $\mathrm{CaCO}_{3}$, assuming a $\delta^{13} \mathrm{C}$ value of soil $\mathrm{CaCO}_{3}$ of $0 \%$. However, on average, the relative shift of ${ }^{13} \mathrm{C}$ represents only around $15 \%$ addition of soil $\mathrm{CaCO}_{3}$. This is the same shift represented by the ${ }^{14} \mathrm{C}$ concentration in recharging groundwater, where the $15 \%$ reflects the amount of "dead" soil $\mathrm{CaCO}_{3}$ incorporated in the DIC. The agriculturally recharged groundwater DIC most likely is slightly lighter due to the unnaturally high levels of soil $\mathrm{CO}_{2}$ found below irrigated crops. This causes more $\mathrm{CO}_{2}$ to be available for communication with the DIC at any given time, resulting in a smaller shift from equilibrium.

Only one area in general on the southwest side of the Brentwood region have naturally recharged groundwaters been recognized (Fig 10a). This area includes wells BR-18, BR-38, BR-43, and BR-70-1. The model ${ }^{14} \mathrm{C}$ ages of these waters range from 324 to 7072 years old (Table 2). BR-43 is a low capacity water supply well completed in the Eocene rocks at the valley edge and has the oldest age of this group. Both BR-38 and BR-70-1 are perforated $\sim 150 \mathrm{fbs}$, and appear to be from somewhat confined zones based on a lack of agricultural water recharge at their depths, in contrast to other wells of similar depth in this region. BR-18 is deeper, perforated from $\sim 250$ to $400 \mathrm{fbs}$. Its age is roughly the same as the natural groundwater at $150 \mathrm{fbs}$.

Naturally recharged groundwater is also observed in the eastern and northern parts of the Brentwood region (Fig. 10a). Model ages of these groundwaters range from 2100 to 11,800 years old (Table 2). The oldest groundwater ages occur in wells BR-73 and BR-88, which are located in the southeastern part of the Brentwood region. Both have perforations $\sim 300 \mathrm{fbs}$. BR- 65 is a shallower well $(\sim 130 \mathrm{fbs})$ located just to the north of 
the latter two wells and has a model age of $\sim 2100$ years. BR-63 is also a shallow well ( $\sim 110 \mathrm{fbs})$ further north, but has a considerably older age of $\sim 6700$ years. In contrast, well BR-69 located even further north, has an $-250 \mathrm{fbs}$ depth, but a model age of only 2600 years. These variable age-depth comparisons provide direct evidence of the different natural flow rates in the groundwater aquifers that are controlled primarily by variations in subsurface permeability. The best example of this is in the northeastern part of the Brentwood region in the areas of poor soil drainage. This area is underlain by tile drains that facilitate subsurface agricultural runoff. This area is dominated by clay-rich soil and downward percolation of groundwater is limited. Most groundwater sampled in this area has little agricultural groundwater recharge, and for the most part represents locally recharged pristine groundwater (Fig. 10a). Likewise, the ${ }^{14} \mathrm{C}$ model ages range from 3900 years at $120 \mathrm{fbs}$ to 4400 at $160 \mathrm{fbs}$, and indicate a slow natural recharge rate.

In the northern part of the Brentwood region, pristine groundwaters are observed in wells BR-20 (City well \#6), BR-21 (City well \#7), and BR-22 (City well \#8). The ${ }^{14} \mathrm{C}$ model ages for BR-20 and BR-21 are between 2660 and 3290 years for mean perforation depths of $235 \mathrm{fbs}$ and $281 \mathrm{fbs}$, respectively. Both wells have similar depth-to-age ratios as sample BR-69. The pristine groundwater in these three wells in the northern part of the region constitutes the sole water supply to the City of Brentwood, and these three large capacity wells together pump annually $~ 1800$ acre-ft of pristine groundwater that is thousands of years old.

The remaining wells measured for ${ }^{14} \mathrm{C}$ all have some component of agricultural water recharge, and their mixture with the pristine component increases the uncertainty in the ${ }^{14} \mathrm{C}$ age calculation. Their calculated model ages, however, range from modern to as old as 2900 years and generally correlates with the $\delta^{18} \mathrm{O}$ values. Most groundwater of this type is located within the central to northwestern part of the Brentwood region and is best characterized by the $\delta^{18} \mathrm{O}$ measurements. 
Aqueous Chemistry and Water Quality - Waters can be characterized into different types based on their relative chemical concentrations. Commonly workers have employed a graphical method of chemical characterization using a Piper diagram (Fig. 12). Most natural waters are dominated by cations of $\mathrm{Ca}, \mathrm{Na}, \mathrm{Mg}$, and $\mathrm{K}$, and anions of $\mathrm{HCO}_{3}, \mathrm{Cl}$, and $\mathrm{SO}_{4}$, all of which define an individual apex on the two triangular regions of the Piper diagram. The diamond region is the graphical addition of the two triangles. The position of a water's chemistry plotted inside the triangular regions is defined by the milliequivalent proportion of each chemical concentration relative to the other cations or anions. The type of water is defined by the dominant cations and anions dissolved in the groundwater. For example, the Brentwood region groundwaters plot predominantly in the lower half of both the cation and anion fields, with somewhat equal proportions of $\mathrm{Ca}$ and $\mathrm{Na}$, and $\mathrm{HCO}_{3}$ and $\mathrm{Cl}$. These waters in general, can be characterized as CaNa$\mathrm{HCO}_{3} \mathrm{Cl}$ type groundwaters. This classification is consistent with the types defined by Sorenson (1981) in groundwaters of this same region. The circles in the diamond region of Fig. 12 define the total dissolved solid (TDS) concentration of a water, where the larger the diameter of the circle, the higher the TDS. The larger TDS circles in the Brentwood region groundwaters appear to be related to higher proportions of $\mathrm{Cl}$ and $\mathrm{SO}_{4}$ (Fig. 12).

As discussed earlier, the electrical conductivity of a water is a measurement proportional to the TDS. Likewise, the Brentwood region samples generally range in conductivity from 850 to $2000 \mu \mathrm{S} / \mathrm{cm}$. Pristine groundwater is typically around $1000 \pm$ $500 \mu \mathrm{S} / \mathrm{cm}$, whereas groundwaters associated with agricultural recharge approach $2000 \mu \mathrm{S} / \mathrm{cm}$ (Fig. 13). A factor of two difference in TDS between pristine groundwater and agricultural recharge exists and is due primarily from leaching of soluble salts in the soils. The high surface water application rates characteristic of flood irrigation provide a plentiful solvent for soluble salts. In the natural state, semi-arid regions such as central California saw drying of the upper soil zones during the summer months that resulted in a 
steady-state concentration of soil salts. Dramatic increases in the amount of water infiltrating through the soil due to flood irrigation causes the salts to move in solution further than they did naturally, resulting in a higher TDS groundwater toward the saturated zone.

Inspection of the range in chloride concentrations in the Brentwood region groundwater ( $\sim 70$ to $250 \mathrm{mg} / \mathrm{L}$ ) relative to the $\delta^{18} \mathrm{O}$ values (Fig. 14) indicates that part of the increase in TDS from the pristine to the recharged agricultural water is probably caused by leaching of soluble chloride salts. In addition, a moderate increase in $\mathrm{HCO}_{3}$, $\mathrm{Ca}, \mathrm{Mg}$, and $\mathrm{Na}$ also contributes to the higher TDS values of the agricultural recharge water.

The dissolved oxygen (DO) content in groundwater is controlled primarily by reactions with organic matter or oxygen-deficient minerals such as pyrite $\left(\mathrm{FeS}_{2}\right)$ or siderite $\left(\mathrm{FeCO}_{3} ; \mathrm{Hem}, 1985\right)$. In normal groundwater conditions, these reactions typically are slow and occur incrementally along groundwater flowpaths. The DO concentration of groundwater at recharge should be close to the concentration expected in a surface water in equilibrium with atmosphere, that is between 8 and $13 \mathrm{mg} / \mathrm{L}$. In the Brentwood region groundwater, the DO concentration determined by field methods varies between 0.5 to $12.0 \mathrm{mg} / \mathrm{L}$. The DO concentration systematically decreases with increasing groundwater age (Fig. 15). In particular, the highest DO concentrations are observed in agriculturally recharged waters, and the lowest in pristine groundwaters of the oldest ${ }^{14} \mathrm{C}$ ages. This variation is undoubtedly controlled by subsurface reactions utilizing the DO in the groundwater. The reactions at this time are not well understood, but has minimal effect on the results presented in this report. In particular, variations in the $\delta^{13} \mathrm{C}$ values are not consistent with oxidation of significant amounts of organic matter, a reaction that could add "dead" carbon to the groundwater. The ultimate result of these reactions is to create oxygen-deficient groundwater. Such groundwater causes Fe and $\mathrm{Mn}$ to become soluble, elements that typically have low solubilities in oxygenated 
waters. Fe and $\mathrm{Mn}$ are the greatest water quality concern in deeper wells ( $>300 \mathrm{fbs})$ in the Brentwood region. For instance, BR-18 (City well \#10) is completed between 250 and $400 \mathrm{fbs}$ and had a DO concentration of $<1.0 \mathrm{mg} / \mathrm{L}$. The groundwater from BR-18 was analyzed to have $0.221 \mathrm{mg} / \mathrm{L} \mathrm{Fe}$ and $0.193 \mathrm{mg} / \mathrm{L} \mathrm{Mn}$ (Table 3).

Excessive nitrate levels are the most serious water quality problem associated with the agricultural recharge waters (Fig. 11). Typically, agricultural fields are fertilized with anhydrous ammonia in California that is usually added to the surface water at the flood irrigation point. The ammonium ion $\left(\mathrm{NH}_{4}{ }^{+}\right)$is transformed to a dissolved nitrate ion $\left(\mathrm{NO}_{3}{ }^{-}\right)$through an oxidation process known as nitrification (Hübner, 1986). Nitrification can be qualitatively shown by example in the Brentwood waters. Surface canal water and tail water (BR-1 through BR- 6 and BR-8 through BR-11) were field measured for their nitrate content, which ranges from 0 to $15 \mathrm{mg} / \mathrm{L}$ as nitrate. Tail water is applied irrigation water that has circulated on the surface through the furrows but did not infiltrate into the subsurface. BR-7, on the other hand, was sampled from the subsurface tile drain discharge in the eastern Brentwood region and represents groundwater that has recently infiltrated the subsurface below irrigated and fertilized fields. The nitrate concentration of BR-7 is $>100 \mathrm{mg} / \mathrm{L}$, or nearly ten times that of the canal water. Nitrate fertilizer application rates are on average applied at a rate of $525 \mathrm{lbs}$ as nitrate annually for every cultivated acre in California (Stephany et al., 1989). The amount of nitrate observed on average in the Brentwood region groundwaters can be supplied by these fertilization rates within 10 years.

In addition, the annual cycle of irrigation water application at rates far exceeding natural rain recharge rates (see below), causes the leaching of salts that naturally accumulated in the shallow subsurface (Fig. 12). Similar processes, but much more severe, are occurring in the San Joaquin Valley, where subsurface irrigation return water from tile drain systems has dramatically increased in salinity during infiltration and leached toxic levels of the element selenium (see Gilliom et al., 1988 for review). 
Comparison of EC measurements from the canal water to the BR-7 and other groundwaters with an agricultural recharge origin shows that the EC levels in the canal water is 3 times less than the groundwater. In addition, the EC levels increase by a factor of two between the pristine groundwater and the recharged agricultural water (Fig. 12).

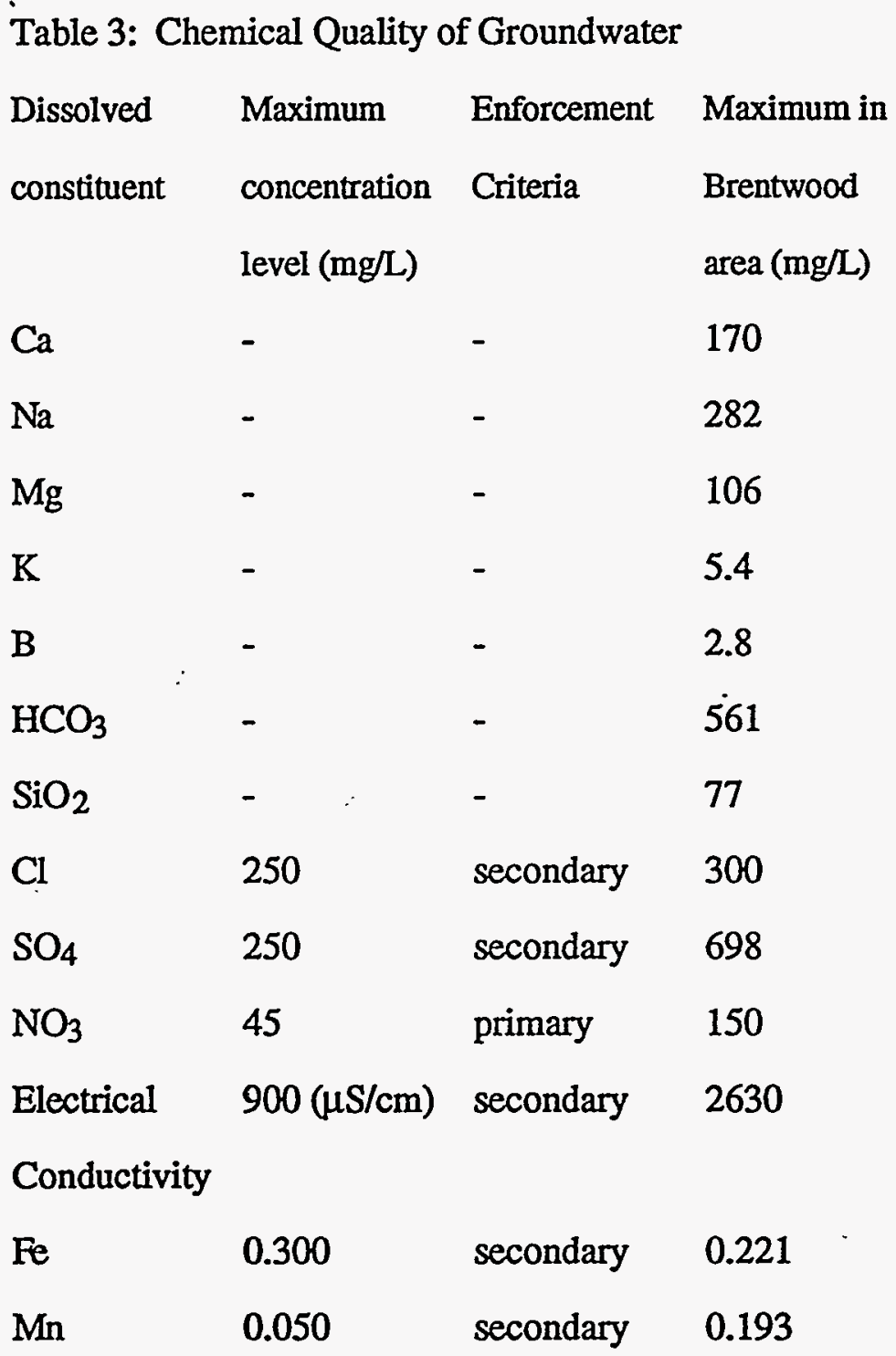

Table 3 compares maximum observed concentrations in groundwater of the Brentwood region to the recommended or enforced levels by the EPA. Chloride, sulfate, and more commonly electrical conductivity exceed recommended levels. These 
standards are not enforceable by law. The nitrate concentrations are enforceable by law when groundwater is distributed for drinking water purposes. Although the nitrate determinations made for this report are not EPA certified, they do indicate that many groundwaters throughout the region are close to or exceed drinking water standards. High levels of dissolved iron and manganese are usually associated with oxygen deficient water. BR-18 (City well \#10) exceeds drinking water standards for these elements and has associated low dissolved oxygen levels. Groundwater quality of the type found in BR-18 could be common in the deeper groundwaters of the Brentwood region, and were recognized throughout the region at depth by Berkstresser (1973).

\section{Discussion}

The remainder of this report will focus on groundwater recharge to the Brentwood region, and a model will be developed that describes and predicts the behavior of the groundwater system in 1) the natural state 2) the agricultural land use, and 3) urbanization of the land. From this model, analyses and recommendations will emerge for 1) municipal pumping, 2) exploring of new groundwater resources, and 3) gathering data for the regular groundwater basin management.

Natural Groundwater Recharge and Flow - Quantifying the natural groundwater recharge rates to the Brentwood region serves two important purposes: 1) comparison of the natural recharge rates to the modern provides a rate and the extent the groundwater basin has changed in response to the land use during the past $\sim 80$ years, facilitating prediction of the groundwater response in future land use scenarios; 2) quantifying the recharge mechanisms will help in determining the availability of new groundwater resources, aiding the prediction of their occurrences. Quantifying natural recharge rates relies primarily on the results from the ${ }^{14} \mathrm{C}$ measurements. Owing to the fact that inorganic carbon dissolved in groundwater is a product of shallow groundwater reactions, 
exact ages of groundwater determined solely from the ${ }^{14} \mathrm{C}$ calculations always have some margin of error. In the case of the Brentwood region analyses, the dissolved carbon concentrations and the $\delta^{13} \mathrm{C}$ results show only minor variations throughout the sampling area and indicates that the dissolved carbon is behaving for the most part conservatively with respect to the groundwater flow.

The rate of groundwater flow can be defined by dividing the ${ }^{14} \mathrm{C}$ model age into the distance between a recharge point and a sampling point. Flow rates can be calculated for vertical transport or for lateral transport (Fig. 16). For vertical transport, the distance is the length between the ground surface and the average perforation depth. For lateral transport, a maximum distance of lateral transport can be defined by determining the distance between the sampling point and the western edge of the Brentwood region where the Eocene rocks are exposed. The western edge is a hypothetical recharge point that assumes that the groundwater contributions from the Eocene rocks are negligible. This result will provide a maximum flow distance, and hence a maximum lateral flow rate. Vertical and lateral flow rates have been calculated from the ${ }^{14} \mathrm{C}$ ages of the pristine groundwaters and are tabulated in Table 4. 
TABLE 4: Flow rates of pristine groundwaters.

$\begin{array}{lllll}\text { Sample } & \text { Distance/Age } & \text { Lateral Flow } & \text { Depth/Age } & \text { Vertical Flow } \\ & \mathrm{ft} / \mathrm{yr} & \text { Rate } \mathrm{ft} 3 / \mathrm{yr} & \mathrm{ft} / \mathrm{yr} & \text { Rate } \mathrm{ft}^{3} / \mathrm{yr} \\ \text { BR-14 } & 5.2 & 1.6 & 0.036 & 0.011 \\ \text { BR-18 } & 8.6 & 2.6 & 0.243 & 0.073 \\ \text { BR-20 } & 4.0 & 1.2 & 0.088 & 0.026 \\ \text { BR-21 } & 3.3 & 1.0 & 0.089 & 0.027 \\ \text { BR-38 } & 1.5 & 0.5 & 0.079 & 0.024 \\ \text { BR-55 } & 3.9 & 1.2 & 0.039 & 0.012 \\ \text { BR-62 } & 4.9 & 1.5 & 0.062 & 0.019 \\ \text { BR-63 } & 3.2 & 1.0 & 0.016 & 0.005 \\ \text { BR-65 } & 11.9 & 3.6 & 0.069 & 0.021 \\ \text { BR-66 } & 5.3 & 1.6 & 0.062 & 0.019 \\ \text { BR-69 } & 10.6 & 3.2 & 0.098 & 0.03 \\ \text { BR-70-1 } & 23.0 & 6.9 & 0.571 & 0.171 \\ \text { BR-73 } & 2.7 & 0.8 & 0.036 & 0.011 \\ \text { BR-88 } & 2.3 & 0.7 & 0.026 & 0.008 \\ \text { AVERAGE } & 6.5 & 1.9 & 0.108 & 0.032\end{array}$

Close inspection of the calculated flow rates indicates that there is over a factor of ten range in both the lateral and the vertical components. Most notable are samples BR18 and BR-70-1, which have the highest vertical and lateral flow rates. These wells also occur closest to the western edge of the Brentwood region, or closest to the hypothetical recharge point. None of the wells in the eastern part of the Brentwood region indicate such high flow rates. The implication from the more rapid flow rates in BR-18 and BR$70-1$ is that they are completed in aquifers that are more rapidly recharged than other aquifers in the region. Such rapidly recharged aquifers would be more likely to exist in 
the western part of the Brentwood region where natural streams draining the hills in the west deposit coarse-grained sediments at the topographic break between the Eocene rocks and the overlying alluvium where stream energy loss occurs. The coarser sediments in the western part of the region is also reflected in the soil types of the Brentwood region (Fig. 2), where the predominantly clay loams in the west grade into clays in the east.

It is interesting to note that BR-18 lies directly down slope of Deer Creek Valley (Fig. 1). It is likely that coarse-grained stream sediments have preferentially deposited in the Deer Creek Valley area over geologic time, creating permeable channels downslope to the east. BR-18 may intercept such channels whose recharge would represent runoff and seepage from the hills above Deer Creek Valley, that are focused into permeable aquifer layers. BR-70-1 likewise lies directly down slope of Briones Valley, and the aquifer that it is completed in may be recharged by a similar mechanism.

Comparison of the lateral flow rates with the vertical flows rates indicates that the differential velocities are around one order of magnitude. Horizontal permeabilities in sedimentary material commonly exceeds the vertical permeability (Domenico and Schwartz, 1990) due primarily to the geometry of fluvial deposits and the horizontal stratigraphic layering of high permeability sediments with low permeability sediments, for example gravel with silt. The calculated vertical flow rates have a greater certainty than the lateral rates due to the simple fact the distance between the surface and the sampling depth is better known than the lateral distance between the recharge area and the sampling point. A simple comparison of the lateral and vertical flow rates can be made by calculating the annual recharge to the basin under pristine conditions by using the average values in Table 4. In the case of the lateral flow rate, a hypothetical "box" of groundwater flowing eastward across the Brentwood region (Fig. 16) has three sides with lengths of $500 \mathrm{ft} \times 26,400 \mathrm{ft} \times 1.9 \mathrm{ft} / \mathrm{yr}$, and a $30 \%$ average porosity. The flux of the groundwater mass is calculated to be 25.1 million $\mathrm{ft} 3 / \mathrm{yr}$, or 576 acre-ft/yr of groundwater moving eastward annually (Fig. 16). This total flow is also equivalent to the annual 
average recharge to the Brentwood region under pristine conditions. In the case of the vertical flow rate, using the average value of $0.031 \mathrm{ft} / \mathrm{yr}$ over an area of $26.6 \mathrm{mi}^{2}$, gives a yearly recharge volume of 23.0 million $\mathrm{ft}^{3} / \mathrm{yr}$ or 528 acre-ft/yr as downward flow (Fig. 16). The recharge volumes derived from the vertical and lateral flow rates are consistent within $<10 \%$ of each other, even though the lateral flow rates are a maximum calculated velocity. The lateral velocities at the scale of the entire Brentwood region probably do not vary more than $\pm 10 \%$ of the values shown in Table 4 . Therefore, the calculated natural recharge to the Brentwood region, as derived from the ${ }^{14} \mathrm{C}$ determinations, is $\sim 550$ acre-ft/yr. This is equivalent to on average $\sim 21 \mathrm{acre}-\mathrm{ft} / \mathrm{mi}^{2}-\mathrm{yr}$ of natural recharge.

Modern Groundwater Recharge - The groundwater recharge since the introduction of agricultural irrigation can be inferred from the contoured $\delta^{18} \mathrm{O}$ values in the Brentwood region (Fig. 10a and 10b). Agricultural irrigation water has penetrated the deepest in the western side of the area, defined by a broad zone that parallels the hilly regions on the western edge. Agricultural recharge in this zone penetrates deeper than $200 \mathrm{fbs}$ in some wells and averages between 125 and $150 \mathrm{fbs}$ (Figs. 10a and 10b). In the northeastern part of the region and the eastern edge of the study area, the agricultural irrigation recharge is not well defined and local rain water $\delta^{18} \mathrm{O}$ values are observed instead at relatively shallow depths ( $150 \mathrm{fbs})$. The northeastern part of the Brentwood region historically has had poor subsurface drainage and is currently lined with tile drains. This has limited the vertical penetration of recharged agricultural irrigation water over the years. A similar condition may explain why deep vertical penetration of agricultural irrigation water is not observed in the eastern part of the Brentwood region. This is also consistent with the geologic and soil observations that coarser material is more common in the western part of the basin and finer material is more common in the eastern part of the basin. Deeper vertical migration of the agricultural water would be expected for the coarser material. 
The presence of agricultural irrigation recharge at depths 125 to $150 \mathrm{fbs}$ implies that average vertical infiltration rates of flood irrigation water over the past 77 years are between 1.6 and $1.9 \mathrm{ft} / \mathrm{yr}$. Assuming a $30 \%$ porosity and an average surface water application of $1.8 \mathrm{ft} / \mathrm{yr}$ (see below), then between $27 \%$ and $32 \%$ of the applied irrigation water is recharging to the aquifers and in general the crop water efficiency is around $70 \%$. On average, the implied vertical infiltration rate of the agricultural water is between 16 and 19 times greater than the vertical infiltration rate of pristine groundwater in the natural state as implied from Table 4. Adding the agricultural recharge rate (1.6 to 1.9 $\mathrm{ft} / \mathrm{yr})$ to the natural vertical recharge rate $(0.108 \mathrm{ft} / \mathrm{yr}$; Table 4$)$, we see that the rain recharge is only 5 to $6 \%$ of the total annual recharge to the Brentwood region. More realistic but less quantifiable though, the cultivation of the soil and removal of native plants in the Brentwood region for agriculture probably allows greater rain water recharge on an annual basis. In urbanized areas, though, pavement and water efficient plants such as grass most likely prevent significant rain recharge, and results similar, if not less, to rain recharge rates in the natural state are expected.

No evidence was observed during this study that indicated Marsh Creek recharged into shallow groundwater aquifers. Marsh Creek water originates from the Coast ranges to the west and is expected to have a $\delta^{18} \mathrm{O}$ value higher than local rain due to evaporation. The sample of Marsh Creek (BR-15) collected at Dainty Rd. indicates that it predominantly comprises irrigation return water of a much lower $\delta^{18} \mathrm{O}$ value. This may be the primary water source of Marsh Creek in the summer time during irrigation, but in the winter time, it should comprise more local sources of higher $\delta^{18} \mathrm{O}$ values. Such high values are not observed in groundwater that has been sampled in close proximity to the creek, while most recharge water in the shallow groundwater is observed to be derived from agricultural irrigation. Therefore, if groundwater recharge from Marsh Creek occurs, it is occurring at a much slower rate than annual agricultural flood irrigation infiltration. 
Groundwater Model - The following discussion will address a regional-scale mass balance model for the groundwater resources of the Brentwood region. Six general components comprise the mass balance model: 1) agricultural irrigation water recharge, 2) recharge from local precipitation, 3) recharge from stream loss, 4) agricultural pumping, 5) domestic pumping, and 6) groundwater underflow that leaves the Brentwood region by easterly flow. The first three components represent groundwater that annually enters groundwater storage. The latter three components consist of groundwater that is annually removed from storage. The sum of the latter three components subtracted from the sum of the first three components is the total change in storage of the groundwater basin. For the Brentwood region the change in storage is essentially zero as indicated by the uniform water table levels in wells throughout the region over at least 50 years (Fig. 6). The groundwater flow (component \#6 above) is the most important part of the mass balance model since this represents groundwater available for consumption. The groundwater flow (component \#6) can be calculated such that,

\section{Groundwater Flow $=$ Total Recharge - Total Pumped}

where the total recharge is the sum of components $1-3$, and the total pumped is the sum of components 4 and 5 . Listed below are the quantities of groundwater in each component calculated from available data spanning the past 77 years, and a discussion of their derivation follows. 
Table 5: Groundwater Balance-in acre-ft over 77 years (1917-1994).

\begin{tabular}{|llll|}
\hline Component & Maximum & Minimum & Mean \\
Ag Recharge & 694,000 & 487,300 & \\
Rain Recharge & 144,190 & 42,350 & 590,650 \\
Stream Recharge & 83,600 & 0 & 93,270 \\
Ag Pumping & 288,700 & 288,700 & 41,800 \\
Domestic Pumping & 73,540 & 73,540 & 288,700 \\
Groundwater Flow & 559,550 & 167,410 & 73,540 \\
\hline
\end{tabular}

\section{Agricultural Recharge}

The ECCID has extensive historical records on the amount of water annually diverted and delivered for irrigation dating from 1917 to 1972 (Fig. 17). Irrigation water records from 1950 to 1972 specify the total water delivery as 1) surface water diverted at Indian Slough and 2) groundwater pumped into the delivery canals. In addition, the total water lost from inferred canal seepage was calculated by ECCID and typically averaged around 7\%. Irrigation water records from 1917 to 1949 were measured only as the total water diverted at Indian Slough and lacked groundwater pumpage and seepage loss data. It is not clear how much groundwater was pumped before 1950 but estimates are provided below. The total agricultural irrigation water before 1950 was calculated by subtracting a 7\% water loss by seepage from the diversion quantities at Indian Slough, but no groundwater inputs were added.

The data distribution in Fig. 17 shows a regular increase in irrigation water deliveries over time. Extrapolation of the trend beyond 1972 would suggest a linear increase in agricultural irrigation water applied above the 1972 quantity. For the purposes of this report, though, a more conservative estimate is used instead, since irrigation water distribution over the entire ECCID in 1972 was nearly $100 \%$ of the 
available acreage during this period, and any increased application beyond 1972 is unlikely. Assuming that the delivery of annual agricultural irrigation water approaches a steady-state amount subsequent to 1972 , a total of $~ 37,550$ acre- $\mathrm{ft}$ per year is calculated. Therefore, the steady state quantity of 37,550 acre-ft per year is used as the amount applied to the land annually between the years 1972 and 1994. Also in Fig. 17, the total water delivered from 1930 to 1944 does show somewhat of a decreasing trend and may be related to increasing groundwater inputs that are not included in the data.

When the irrigation water delivered is integrated over 77 years, the total is $2,313,230$ acre-ft that was applied over $\leq 17,000$ acres. This amount is equivalent to an average of $1.8 \mathrm{ft}$ per year applied for irrigation per acre, and is about one-half the current average (3.6 ft per year) in California (Snyder, et al., 1986). The $1.8 \mathrm{ft}$ per year assumes that $100 \%$ of the 17,000 acres was irrigated over the 77 years and ignores fallow land and areas where high water consumptive crops such as fruits were grown. For the mass balance model it is assumed that the irrigation water efficiency on average is $70 \%$, and $30 \%$ of the total irrigation water applied is recharged to the groundwater basin. This results in 694,000 acre-ft of total groundwater recharge over 77 years.

The total agricultural water recharged over the 17,000 acres is equivalent to approximately $41 \mathrm{ft}$ of applied water at the surface or $136 \mathrm{ft}$ of aquifer volume, assuming a $30 \%$ porosity. This total depth of groundwater recharged by agricultural irrigation (136 $\mathrm{ft}$ ) is essentially the approximate average depth of irrigation recharge observed in the $\delta^{18} \mathrm{O}$ values and $\mathrm{NO}_{3}$ concentrations. The comparison is a quantitative validation of the agricultural recharge component of the model.

The total agricultural water recharge calculated from the water delivery data is considered to be a maximum value. A lower limit, or a minimum amount of agricultural recharge can be inferred based on calculating the volume of the agricultural water from the $\delta^{18} \mathrm{O}$ pattern of Figs. $10 \mathrm{a}$ and $10 \mathrm{~b}$. A uniform $30 \%$ porosity is assumed. The simplest integration from the $\delta^{18} \mathrm{O}$ pattern suggests that the total recharge is 487,300 acre-ft over 
the total 77 years. Averaging of the maximum and the minimum agricultural recharge values gives a mean value of 590,650 acre-ft over the 77 years.

A similar average can also be calculated by determining the average percentage of agricultural recharge water in any well and integrating this amount over a calculated average perforation depth from wells sampled in the Brentwood region. The percentage of agricultural recharge water mixed in a groundwater sample can be calculated from a mass balance equation such that,

$$
x_{a g}=\frac{\delta^{18} O_{\text {meas }}-\delta^{18} O_{p p t}}{\delta^{18} O_{a g}-\delta^{18} O_{p p t}}
$$

where $x_{a g}$ is the percentage of agricultural recharge water, $\delta^{18} O_{\text {meas }}$ is the measured value of the groundwater sample, $\delta^{18} O_{p p t}$ is the value of pristine rain water chosen to be $-6.8 \%$, and $\delta^{18} \mathrm{O}_{a g}$ is the value of agricultural water. The agricultural recharge value of $-8.5 \%$ was used, initially. Some groundwaters, though, resulted in greater than $100 \%$ agricultural recharge. Therefore, these groundwaters were recalculated with a agricultural recharge value of $-9.2 \%$. This is consistent with the fact that the canal water which starts at $-9.2 \% o$ at the first lift station evaporates to around $-8.7 \%$ in canal laterals in the west part of the region, and recharge agricultural water over this entire $\delta 180$ range is expected. In short. an average amount of agricultural recharge water of $55 \%$ of the total was calculated from all the sampled wells. Likewise, an average perforation depth of $192 \mathrm{fbs}$ was determined from all the available well data. Using these two parameters and the same geographic limits $\left(26.6 \mathrm{mi}^{2}\right)$ and average porosity (30\%), a total amount of agricultural recharge in the Brentwood region is 539,320 acre-ft. This value is within $10 \%$ of the average value calculated above in Table 5. 


\section{$\underline{\text { Rain Recharge }}$}

Rain recharge is calculated based on the ${ }^{14} \mathrm{C}$ results discussed above (see Table 4), where natural rain recharge rates were calculated to be $\sim 550$ acre-ft per year. Taking this rate as a minimum, a total of 42,350 acre-ft were recharged over 77 years. A maximum recharge rate can be derived by considering that rain recharge has probably been greater during the past 77 years due to the cultivation of the soil for farming and removal of native plants. In this case, it is assumed that the $26.6 \mathrm{mi}^{2}$ area recharges $10 \%$ of the total rain $(0.11 \mathrm{ft} / \mathrm{yr})$, which results in 1870 acre-ft per year or 144,190 acre-ft over 77 years. It should be noted from Table 5 that the agricultural recharge volume is approximately 5 to 12 times greater than the rain recharge volume.

\section{Stream Recharge}

Marsh Creek is the only surface water that could contribute appreciable recharge to this area. Flow data are not available at this time, but annual average flow is estimated at 5 cubic feet per second. Assuming at most $30 \%$ of this water is lost as groundwater, a total of 83,600 acre-ft could be recharged. Qualitative observations of Marsh Creek, though, indicate no significant losses occur and recharge could be essentially zero. The stable isotope data of the groundwater do not indicate any definable source directly from Marsh Creek.

\section{Agricultural Pumping}

This component comprises all water derived from groundwater pumping by the ECCID. The ECCID has thorough records on total groundwater pumped between 1950 and 1972. The groundwater was pumped for two reasons: 1) to augment irrigation supplies in the canals, and 2) to provide drainage to areas with high water tables that are lined by tile drains in the northeastern part of the Brentwood region. Typically, 30-50\% of the total groundwater pumped by the ECCID was for enhancement of drainage, and 
that water was always disposed of outside the Brentwood region. Total groundwater pumped annually between 1950 and 1972 generally decreased between $\sim 6000$ to 4500 acre-ft (Fig. 18). Because detailed data are not available subsequent to 1972, annual groundwater extractions from 1972-1994 are estimated at 4500 acre-ft per year. Annual extractions prior to 1950 are less clear. Large capacity pumps only became routinely accessible during the early 1930's (Thomasson et al., 1960). Therefore, for convenience, the rate estimated for groundwater pumped by ECCID from 1935-1950 is 4500 acre-ft/yr. The total groundwater pumped from the Brentwood region by the ECCID over the 77 years is calculated at 288,700 acre-ft. No maximum or minimum values were calculated for this component.

Agricultural pumping from privately owned wells was probably insignificant during the 77 years. Most water used for irrigation was available at affordable rates from the ECCD.

\section{Domestic Pumping}

Groundwater pumped by individual well owners and the municipalities of Brentwood and Knightsen can be estimated from general population figures available at the ECCID. Better population data may exist elsewhere but has not been compiled for this report. The ECCID records indicate that between 1950 and 1961 the population was close to 5000 . Between 1962 and 1968 the population was 6000 . The population is reported as 8000 in 1968, and for this report, that figure has been extended through 1985. A population of 10,000 is used from 1986 to 1994 . Between 1917 and 1950, where no records are available at this time, the population is estimated at 2500 . It is assumed that the per capita daily water use is 164 gals (City of Brentwood-CCWD, 1990) and is similar to municipalities like the City of Davis where 3.7 billion gals are consumed annually by $\sim 50,000$ people (Davisson and Criss, 1993). Summing up the groundwater pumped for domestic consumption over the 77 years using the population figures 
provided above, a total of 73,540 acre-ft is calculated. No uncertainty is derived for this value either, but the total groundwater pumped for domestic use is a small percentage of the total mass balance.

\section{Groundwater Flow}

As stated above, the difference between the recharge and the discharge is the groundwater flow and is calculated at a mean value of 394,830 acre-ft. This groundwater represents flow that must leave the Brentwood region in order to create aquifer volume for the groundwater recharged over the past 77 years. The groundwater flow also represents a total amount of groundwater that was not used for consumption, but its yearly amount is theoretically available as a water resource. The total groundwater flow represented as an annual supply over the 17,000 acre region is calculated at 193 acre$\mathrm{ft} / \mathrm{mi}^{2}$ per yr. For a projected population of $\sim 70,000$ in the year 2020 (City of Brentwood-CCWD, 1990), it is estimated approximately 12 square miles will be developed. Simply multiplying the 193 acre- $\mathrm{ft} / \mathrm{mi}^{2}$-yr by the $12 \mathrm{mi}^{2}$, results in a groundwater yield of 2316 acre-ft per year over the developed area. This yield falls within the 2000-4000 acre-ft per year range estimated by Henneman (1990). This groundwater yield, though, does not account for groundwater recharge loss due to agricultural land retirement and urban development, and actual yields will be much less as discussed below. It is also assumed in this simple model that the aquifer below the Brentwood region is homogeneous and isotropic. Real aquifer conditions are heterogeneous and actual yields may vary depending on location within the Brentwood region. Safe yield values presented are considered more or less averages.

Projected Groundwater Yields - The mean projected groundwater yield calculated above (2316 acre-ft) represents an average yield over the 77 year data history. But when the influence of the change in land use practice on the groundwater mass balance is taken 
into account, a different yield scenario is projected. The most significant modern recharge source to the groundwater basin is the applied irrigation water as indicated by the stable isotope, ${ }^{14} \mathrm{C}$, and $\mathrm{NO}_{3}$ data. This recharge component represents close to $90 \%$ of the total recharge over the past 77 years. Retiring agricultural land removes this recharge source. Likewise, suburban or urban development of retired agricultural land further results in a reduction of available recharge areas for precipitation due to increase land coverage of pavement and water efficient plants such as grass. Therefore, it is estimated that the urbanization of agricultural land causes over a $90 \%$ reduction in groundwater recharge. The increase in urban and suburbanization will have a major impact on the groundwater availability.

A simple mass balance model can be developed to quantify the change in groundwater yield per square mile as land is converted to urban uses, and follows such that

$\frac{R}{m i^{2}}=\frac{\text { acres }_{a g} \frac{f t}{y r}(0.55-0.22)+0.05 \frac{f t}{y r}\left(\text { acres }_{u r b}\right)-0.1 \frac{f t}{y r}\left(\text { acres }_{d r a i n}-\text { acres }_{\text {drain }} \text { lost }\right)}{26.6}$

where $R$ is the total annual recharge in acre-ft/mi ${ }^{2}$-yr (equivalent to safe yield), acres $a g$ is the number of acres irrigated for agriculture, acres urb is the number of acres converted to suburban or urban use, acres drain is the number of acres drained by tile drains in the eastern part of the Brentwood region, or approximately 6000 acres, and $0.05 \mathrm{ft} / \mathrm{yr}$ is equivalent to $\sim 5 \%$ of annual precipitation estimated to recharge in an urban setting. Agricultural recharge $(0.45 \mathrm{ft} / \mathrm{yr})$ combined with precipitation recharge $(\sim 0.1 \mathrm{ft} / \mathrm{yr})$ in the agricultural areas is $0.55 \mathrm{ft} / \mathrm{yr}$ and is calculated from the mean values in Table 5. The amount of water consumed by agricultural pumping is $0.22 \mathrm{ft} / \mathrm{yr}$. The sum of acres ag and acres urb always equals 17,000 acres. Figure 19 indicates the change in groundwater yield per square mile per year as the projected population increases. The population increase 
was calculated by assuming 8.8 people per acre in an urban development scheme. Line (a) was calculated with the above equation and indicates that approximately 1 acre- $\mathrm{ft} / \mathrm{mi}^{2}$ per year of groundwater is lost for every 1000 person increase in population. The minor inflection point in the trend is where urbanization begins to encroach on the agricultural areas underlain by tile drains. At a projected population of $\sim 70,000$ people, Fig. 19 suggests that approximately $115 \mathrm{acre}-\mathrm{ft} / \mathrm{mi}^{2}$ per year will be available for groundwater consumption at a safe yield. This is equivalent to 1430 acre-ft per year over a $12.4 \mathrm{mi}^{2}$ area, or $11 \%$ of the total water demand from a population of 70,000 .

Line (b) in Fig. 19 was calculated using a similar equation as above but one that only considers a total acreage of 8000 acres and ignores groundwater contribution from the outlying regions. The 8000 acres is equivalent to the total land urbanized for a projected $\sim 70,000$ person population. The reduction rate of the safe yield for this 8000 acre scale, though, is approximately 2.5 acre-ft per 1000 people increase in population. At a $\sim 70,000$ person population, the safe yield at the 8000 acre scale is approximately 30 acre- $\mathrm{ft} / \mathrm{mi}^{2}$-yr or 372 acre-ft per year for the entire 8000 acres. This is equivalent to $3 \%$ of the total water demand for a population of 70,000 .

The 1430 acre-ft per year estimate for groundwater yield assumes that all the groundwater recharged by agriculture can be captured for domestic groundwater pumping. The 372 acre-ft per year yield assumes that no agricultural recharge can be captured by domestic pumping. Therefóre, 1430 acre-ft per year is an upper limit of safe yield and 372 acre-ft per year is a lower limit, both for a population of 70,000 .

Accordingly, the simple model indicates that the City of Brentwood currently is using around 3 times more groundwater per square mile than the average safe yield. This is consistent with observed changes in groundwater levels in the city wells, where the average maximum drawdown among wells \#6, 7, and 8 was $181 \mathrm{fbs}$ in August of 1994, and was a minimum of $125 \mathrm{fbs}$ in the following fall and proceeding winter months (Mark Linkowitz pers. comm, 1995). The city's groundwater use results in a persistent cone of 
depression with only around a $30 \%$ recovery during low demand months. If the population reaches 70,000 within the next 25 years, the city must decrease their groundwater consumption by approximately $90 \%$ of the total derived by this time in order to approach a safe yield.

The lower limit safe yield is more realistic than the higher one. This is due to the fact that currently the City of Brentwood overlies parts of the recharge area to the groundwater basin. The growth plan for Brentwood stretches into the northwestern part of the basin where more recharge areas occur. Most importantly, Brentwood will be upgradient of most of the agricultural irrigation in the proposed $\mathrm{Ag}$ core, and in order to capture groundwater flow from irrigation recharge, domestic pumping would have to reverse the regional groundwater flow towards the west. This would require large regional drawdowns $(\geq 50 \mathrm{ft})$

With urban growth, the City of Brentwood seeks to augment $20 \%$ of its total water demand with groundwater (City of Brentwood-CCWD, 1990), an amount equivalent to $\sim 3000$ acre-ft/yr over the next 25 years. If this quantity were to be used from the groundwater basin, then a groundwater overdraft would result. This would result in an regional average deflation of the current water table level $\leq 25 \mathrm{ft}$ of the current elevation over 25 years.

Lastly, any long-term use of the current groundwater for domestic consumption must incorporate clean up costs of the dissolved nitrates. Although not all groundwater exceeds the EPA drinking water limits for $\mathrm{NO}_{3}$, the projected growth areas for Brentwood overlie some of the highest dissolved $\mathrm{NO}_{3}$ groundwater (Fig. 8a). Under current conditions, the higher nitrate concentrations occur in shallower groundwater. Any cones of depressions developed during groundwater pumping will enhance the downward flow of the higher $\mathrm{NO}_{3}$ groundwater, accelerating the degradation of the potable groundwater surrounding the well (Davisson and Criss, 1993). 
City Production Wells - Currently city wells \#6, \#7, and \#8 (BR-20, 21, 22) supply all the water demands for the City of Brentwood. All three wells are located within a onequarter $\mathrm{mi}^{2}$ area in the northern part of the region and have a combined production around 1800 acre-ft per year. During the summer of 1994, dynamic drawdowns in these production wells reach between 150 and 200 fbs. Static water levels were measured in three wells (BR-25, BR-26, and BR-52) surrounding the city wells during this same period and showed the aerial drawdown of the potentiometric surface due to the groundwater production. Perforation intervals of BR-25, 26, and 52 may share similar horizons to the production wells (Table 1) and are located within one-quarter mile of each (Fig. 1). BR-52 had the deepest depth to water level of $103 \mathrm{fbs}$, where BR-25 and 26 were respectively 67 and $62 \mathrm{fbs}$. These three measurements suggest that the cone of depression formed around the production wells is not circular in shape, but rather elliptical and stretches from northeast to southwest, reflecting the geographic trend in the production well locations.

Because the City of Brentwood in the recent past has been impacted by the increase of dissolved nitrate in their other production wells to the south, evaluation and risk assessment of similar impacts to wells \#6, 7, and 8 are needed. Given that nitrate levels are related to modern recharge of agricultural water (Fig. 11) whose rate of infiltration at this point has been documented and modeled (see above), a simple calculation is formulated relating the rate of agricultural water infiltration to the annual drawdown around the production wells. Using results in Table 5, a combined vertical recharge rate of agricultural water, rain water, and surface water is $0.55 \mathrm{ft} / \mathrm{yr}$ averaged over the entire Brentwood region. This recharge rate occurs over a regional groundwater table gradient of approximately 0.003 (Fig. 6). It is assumed that the radius of influence of the city production wells is 0.5 miles or $2640 \mathrm{ft}$. The average water table gradient around the production wells is therefore 0.057 , assuming an average yearly drawdown of 
$150 \mathrm{fbs}$. Groundwater flow rates are proportional to the groundwater hydraulic gradient such that

$$
v \cdot n=K \nabla h
$$

where $v$ is the average linear flow rate, $n$ is the mean porosity, $K$ is the hydraulic conductivity of the sediments, and $\nabla h$ is the hydraulic gradient. A change in the hydraulic gradient results in a proportional change in the flow rate since porosity and hydraulic conductivity are constants. Therefore, given that $v=0.55 \mathrm{ft} / \mathrm{yr}$ at $\nabla \mathrm{h}=0.003$, then at $\nabla h=0.057, v=10.5 \mathrm{ft} / \mathrm{yr}$, that is, the vertical flow rate increases by a factor of 19 .

Assuming that agricultural recharge water with nitrate levels exceeding the drinking water standard today occur to $150 \mathrm{fbs}$, then in 10 years their depth will be 255 fbs for a total of $105 \mathrm{ft}$ of vertical movement. Minimum perforation levels for the three production wells range from $190 \mathrm{fbs}$ to $265 \mathrm{fbs}$. Therefore, the simple calculation suggests that groundwater comprising $100 \%$ agricultural recharge water could reach the city production wells within 10 years time, possibly causing nitrate levels to exceed drinking water standards. Assumptions and flow rates used in this calculation are not unrealistic, but were selected to represent a worst-case scenario. Agricultural water reaching the production wells may take longer. For instance, in Fig. 3 city wells to the south that are currently out of production accumulated their excessive nitrate levels over 20 years, beginning at $10 \mathrm{mg} / \mathrm{L}$ in 1970 and reaching $50 \mathrm{mg} / \mathrm{L}$ in 1990 . Similar rates of nitrate increase may be expected for production wells $\# 6,7$, and 8 .

Flowpaths - Modern vertical flow rates in the groundwater beneath the Brentwood region were shown above to be approximately 1.6 to $1.9 \mathrm{ft} / \mathrm{yr}$. Modern lateral flow rates are expected to be at least ten times that of the vertical rate based on comparison with rates of pristine flow derived from the ${ }^{14} \mathrm{C}$ results (Table 4). As stated, much of the western part 
of the Brentwood region groundwater is pervasively recharged with agricultural irrigation water most likely due to the coarser-grained soil types in this part of the region. In addition, some of the deepest penetration of the agricultural water is below the City of Brentwood (Fig. 10b). This most likely is a result of cones of depression formed during municipal pumping for domestic water use over a number of years. In addition, agricultural irrigation recharge is also prevalent along a zone parallel to the ECCD irrigation canal (Fig. 10a). It is tempting to consider the zone of $-9.0 \%$ groundwater that parallels the canal to be derived from canal seepage over the years. Two lines of evidence suggests that this is not the case: 1) a 7\% loss of water per year due to seepage along the concrete-lined canal requires a total of 92 million $\mathrm{ft}^{3}$ per year loss. This is equivalent to a $3.0 \mathrm{ft} 3 /$ second flow rate, or similar to a municipal production well running all year long. Given these rates, 1000 seepage points along the canal are required to flow at $1.3 \mathrm{gpm}$, or 100 seepage points at $13 \mathrm{gpm}$. Such leakage rates appear unlikely. 2) The zone of $-9.0 \%$ groundwater has associated high nitrate concentrations. These nitrates have to be derived from fertilizers which are typically incorporated in the soil zone during flood irrigation. Canal seepage would likely infiltrate independent of soil nitrification processes. A more reasonable interpretation of the 7\% loss of canal water would be a combination of evaporative loss along the lined canal, and seepage along unlined portions of the canal laterals.

The zone of $-9.0 \%$ groundwater most likely represents infiltration of irrigation water that is derived directly from canal water along the concrete lines portions, where the $\delta^{18} \mathrm{O}$ values are around $-9.0 \%$. Users of irrigation water down stream of this area or along the laterals use canal water that has experienced some evaporative enrichment along the flow path, and hence, the recharge water is slightly higher in $\delta^{18} \mathrm{O}$. It is therefore reasonable to assume that vertical infiltration in the area along the main canal can be rapid. 
Even though a significant amount of agricultural water has recharged over the past $\sim 80$ years, many groundwaters sampled either represent pristine recharge sources or a mixture of pristine and agricultural recharge (Table 2). As in Table 4, where average pristine flow rates are reconstructed, interpolation of those pristine groundwater ages within the Brentwood region can provide direct evidence for 1) the heterogeneity in the permeability of the sediments, 2) the interconnectedness of the aquifers, and 3) the possible existence of deeper groundwater resources. Figs. 20a and 20b show a map view of inferred flowpaths from the model ${ }^{14} \mathrm{C}$ ages in the Brentwood region and a cross section with contour interpolation of those ages. Since many groundwater samples from the central part of the Brentwood region are agricultural recharge, Fig. 20b is a composite of the entire basin along a west-southwest to east-northeast transect, and is only provided for a general representation of the inferred subsurface permeability in this region. The contours are consistent with other observations, though, such as 1) on the western edge, groundwater ages are youngest and appear to penetrate deeper in the basin, 2) a continuity of groundwater ages exist west to east along the entire basin from $\sim 150$ to 300 fbs, and 3) pockets of old water indicate areas of low permeability particularly in the northeastern part where poor soil drainage occurs. The most salient feature of the cross section is the continuity of groundwater ages within a semi-confined zone that spans only about 2000 years over 6 miles. This suggests a mean flow rate of around $5 \mathrm{ft} 3 / \mathrm{yr}$ at a $30 \%$ mean porosity, and is consistent with the upper-end of natural flow rates within the basin (see Table 4). The implication of the cross section is that groundwater aquifers have good interconnection and preferred flow along the 150 to $300 \mathrm{fbs}$ level. This is also indicated by the common use of groundwater at these levels (Fig. 7b) and, in particular, the productive nature of Brentwood city wells. This zone of preferred flow does appear to narrow to the east and is sandwiched between lower permeable zones. The deeper low permeability zone is represented by levels which Discovery Bay produces groundwater. Furthermore, the deeper low permeability zone also suggests that perhaps a 
deeper aquifer system ( $>400 \mathrm{fbs}$ ) is absent in this region, or if present, it is separated by a low permeability layer.

New Groundwater Resources - Most unexplored groundwater occurs below $300 \mathrm{fbs}$ in the Brentwood region. Various evidence suggest that plentiful and potable groundwater supplies are not common at deeper depths than the current production levels below the Brentwood region. Based on well log records, Berkstresser (1973) indicated that groundwater potability does not exceed 400 feet below sea level in this region. This is further evidenced on the west side of the Brentwood region, where there is a lack of the surface geological exposures that are characteristic of the high-yielding potable aquifers of the Central Valley of California (Fig. 5). The geologic exposures consists only of thin alluvial deposits with lower yielding aquifers from which the City of Brentwood typically pumps. The ${ }^{14} \mathrm{C}$ age relative to the depth of the groundwater indicates that recharge and migration is much slower in these alluvial deposits than in the more productive aquifers in other areas of the Central Valley (Davisson et al., 1993). This slower groundwater flow rate in the alluvial deposits allows more time for the groundwater to undergo natural chemical reactions that decreases the water quality, for instance, buildup of the iron and manganese observed in the deeper groundwater of Brentwood region (Table 3).

Although geologic exposures of the more productive-type aquifers do not appear on the west side of the Brentwood region, these aquifers may exist deeper in the subsurface east of the City of Brentwood. Productive aquifers may occur deeper than 400 feet below sea level, but their quality probably exceeds drinking water standards, although their quality may be improved by treatment at the well head. Well logs in the far eastern part of the Brentwood region suggest that deeper groundwater aquifers may occur (Fig. 7b). If deeper aquifers occur, then they are most likely separated by confining layers (Fig. 20b). 
Of the shallower groundwater, only a $11 \mathrm{mi}^{2}$ area surrounded by the roads of Sellers, Bixler, Delta, and Balfour hosts groundwater that has for the most part been unaffected by recharge of agricultural water (Fig. 10a). This area is dominated by clay-rich sediments that prevent infiltration of the recharge water. Consequently, this area is underlain by subsurface tile drains that facilitate the drainage of the agricultural water. This has prevented the underlying pristine groundwater to be affected by recharging agricultural water. However, the poor permeability of the sediments suggest that aquifers with good yields ( 500 to $>1000$ gallons per minute) may not be common and well development may be limited.

Focused recharge of pristine groundwater appears to have occurred on the west side of the Brentwood region that is likely related to areas such as Deer Creek Valley and Briones Valley. In the geologic past, stream waters from these valleys probably deposited good water-bearing sediments along the western part of the region that today form higher yielding aquifers in the subsurface. An example of a well penetrating this kind of aquifer is BR-18 (City well \#10). Although it is a deeper well (300-400 feet below the surface), the age of the groundwater in this aquifer is much younger than ages observed at similar depths in other parts of the Brentwood region. The location of any exploration drill hole in the western part of the region should consider the proximity to BR-18 and Deer Creek Valley. Likewise, BR-70-1 has the same rapid recharge characteristics as BR-18 but is a shallower well. At BR-70-1, focused recharge may be controlled by the proximity to Briones Valley and similar shallower zones unaffected by agricultural recharge may be present.

A productive zone of groundwater occurs in the southern part of the Brentwood region ranging from 200 to 350 feet below the surface. These groundwaters, though, are currently being affected by recharge of agricultural irrigation water with high nitrate levels. Based on the much older ${ }^{14} \mathrm{C}$ ages of the Discovery Bay wells downgradient, the 
productive groundwater zone in the southern region appears to be a separate groundwater zone. More work is needed to better characterize this area.

Currently, the groundwater aquifers on the northern part of the Brentwood region are productive and of reasonable quality. Shallower groundwater in adjacent areas, though, are observed to have elevated nitrate levels, and the sustainability of good water quality for the northern aquifers is probably limited. The vertical interconnectivity of the shallow and deeper aquifers cannot be ascertained at this time, but data on surrounding wells suggest that they are not independent of each other.

Strategic Management of Regional Groundwater - Reducing the rate of pumping from groundwater wells is the most immediate and effective way to prolong the life of good quality groundwater in the Brentwood region. In the short-term, this would entail a reduction of the pumping rate from individual wells. A large water table drawdown adjacent to a high capacity well increases the rate of downward percolation and lateral migration of high nitrate groundwater toward the well intake. Such large drawdown conditions currently exist in City wells \#6, \#7, and \#8 which supply almost all the City of Brentwood's water from an approximately one-quarter of a square mile area, causing a maximum local drawdown exceeding $100 \mathrm{ft}$ below the surface. If this focused pumping with a large drawdown continues indefinitely, then unsafe nitrate levels could reach the City well intakes within 10 to 20 years.'

An alternative to reduced pumping is well head treatment of nitrate contamination in wells currently out of production. This would offset the demand on wells $\# 6,7$, and 8 , reducing the groundwater deflation in this area and prolong the life of good quality water in these wells. Well head treatment costs for nitrate are outlined in the Groundwater Management Options Report currently under revision at the ECCID. In addition, as deep exploratory wells are drilled within the City of Brentwood incorporated areas, any low water quality due to iron and manganese can be also treated at the well head. Again, 
treatment at some well heads will offset demand on good water quality wells and prolong their lifetime. In the long term, if groundwater is utilized with well head treatment systems, and if safe yields are to be observed, existing models for safe yield projection (Fig. 19) can be used to help maintain groundwater availability in the Brentwood region.

Long-term strategies should consider alternative water sources from inside and outside the groundwater basin. As urban growth continues, less groundwater will be available for pumping at safe-yields (Fig. 19). Cost effective management strategies for groundwater in California today include artificial recharge projects. Such projects typically incorporate 1) engineered surface recharge of excess surface water supplies such as storm runoff or local streams, and/or 2) direct groundwater injection of the surface water and reclaimed waste water. The results of the ${ }^{14} \mathrm{C}$ analyses suggest that groundwater aquifers between 150 and $300 \mathrm{fbs}$ are laterally continuous and may be suitable for injected recharge, and its feasibility could be further explored.

It is recommended in this report that all future use of groundwater in the Brentwood region be considered on a groundwater basin scale. Groundwater used in one part of the basin currently has an impact on another part of the basin, a relation that will become more intimate with time. It is recommended that any comprehensive groundwater management plan incorporate regular diagnostic monitoring of vital groundwater indicators such as 1) regional water table levels twice a year on April 1 and October 1,2 ) regional groundwater Level II water quality surveys every 1 to 5 years depending on the nature of groundwater use, and 3) a stable isotope survey once every ten years to monitor changes in sources and migration of the regional groundwater.

\section{Summary}

Groundwater in the Brentwood region has been characterized using isotope hydrology techniques and have addressed resource issues regarding the future sustainability of groundwater, maintenance of existing supplies, and exploration of new 
supplies. The stable isotopes of oxygen and hydrogen indicate that groundwater is derived from two sources: ancient rain recharge, and recharge of agricultural irrigation water. Rain derived groundwater ages range from $<1000$ to $\sim 12,000$ years old. Agricultural recharge groundwater is $<80$ years and has recharged much of the basin on average to $\sim 125 \mathrm{fbs}$. The agricultural water recharges $>10$ times faster than natural rain water and hence, represents the principal recharge component. The agricultural recharge at the present time provides groundwater quantities to the basin that exceed the yearly water supply demand. With increasing urban development and retiring agricultural land, the availability of groundwater will decrease. Safe yield projections for the groundwater have been modeled to show that safe groundwater yields range between 30 to 120 acre$\mathrm{ft} / \mathrm{mi}^{2}$ per year for a population of 70,000 people. This will only account for $\sim 3$ to $11 \%$ of the total water demand. Furthermore, much of this groundwater may need well head treatment for water quality problems.

Agricultural recharge water generally has excessive dissolved nitrate concentrations that has been shown semi-quantitatively to exceed EPA drinking water limits. These groundwaters also have high dissolved solid contents from soil leaching processes. Shallow pristine water is of a good quality but generally is scarce, where deeper groundwater is of poorer quality due to low dissolved oxygen levels and unsuitable iron and manganese concentrations.

Downward migration of the agricultural recharge water threatens the potability of groundwater from Brentwood city wells \#6, 7, and 8 which presently form a persistent large cone of depression exceeding $100 \mathrm{fbs}$. Increased hydrologic gradients from the cone of depression allows downward flow of agricultural water at rates up to $11 \mathrm{ft} / \mathrm{yr}$, and water quality may be compromised within 10 to 20 years.

The ${ }^{14} \mathrm{C}$ ages in the Brentwood region groundwaters are used to construct an ancient groundwater flow field and subsurface permeability structure. Natural groundwater flow was slow ( -1.5 to $23 \mathrm{ft} / \mathrm{yr}$ laterally). The western portion of the basin 
appears to have recharged deeper and more rapidly and aquifers are less discriminating. The central and eastern part of the basin appears to have well defined, semi-confined aquifer zones between 150 and $300 \mathrm{fbs}$ that appear well interconnected.

Potential areas of groundwater exploration include: 1) a shallow area in the northeastern part of the region, where groundwater is undisturbed from agricultural recharge, but may only provide low yielding wells, and 2) shallow to deep channelized aquifers may exist on the western part of the basin associated with downslope areas from Deer Creek and Briones Valley. City well \#10 appears to have penetrated such an aquifer. Surface geologic evidence suggests that deep productive aquifers do not occur below the Brentwood region, although they may occur in the subsurface east of the City of Brentwood. If deeper groundwater in the region exists, it will have very limited recharge capacity and a likely poor water quality.

\section{Acknowledgments}

We thank Chuck Hamilton, Jay Corey, Chuck Vosicka, and Mark Linkowitz for their helpful advise and discussion during this research. We also acknowledge the guidance of Bob Criss through parts of this research and many other aspects of similar scientific endeavors. 


\section{References}

Berkstresser, C.F., Jr. (1973) Base of fresh groundwater-approximately 3,000 micromhos-in the Sacramento Valley and Sacramento-San Joaquin Delta, California: U.S. Geological Survey Water Resour. Invest. 40-73, 1 map.

City of Brentwood and Contra Costa Water District, 1990, City of Brentwood water supply study. October $19,1990,85$ pgs. .

Colburn, I.P., 1961, The tectonic history of Mount Diablo, California. Ph.D. Dissertation, Stanford University, 234 pp.

Contra Costa Water District, 1993, East County water supply management study. Phase I-supply and demand. Draft. September 1993, 40 pgs.

Craig H., 1961, Isotopic variations in meteoric waters. Science 133, pp. 1702-1703.

Craig H., Gordon L.I., Horibe Y., 1963, Isotopic exchange effects in the evaporation of water. Journal of Geophysical Research 68, 5079-5087.

Davis, G.H., 1959, Groundwater conditions and storage capacity in the San Joaquin Valley California. USGS Water Supply Paper 1469, 287 pgs.

Davisson, M.L. and Criss, R.E., 1993, Stable isotope imaging of a dynamic groundwater system in the southwestern Sacramento Valley, California, USA. J. Hydrol, 144, 213-246.

Davisson, M. L., Criss, R. E. and Campbell, K. R., 1993, Preliminary report on the stable isotope imaging and characterization of surface and ground water resources in the southern Sacramento Valley. Lawrence Livermore National Laboratory, UCRL-ID115393,32 p.

Davisson, M.L., Campbell, K.R., 1994, Preliminary report on the groundwater isotope study in the Brentwood region, Lawrence Livermore Lab Report UCRL-ID-118678, , $26 \mathrm{pp}$.

Department of Water Resources, 1967, San Joaquin County groundwater investigation. California Department of Water Resources Bulletin, 146. 
Domenico, P.A. and Schwartz, F.W., 1990, Physical and Chemical Hydrogeology. John Wiley and Sons: New York, 824 pgs.

Fontes, J. Ch., 1980, Environmental isotopes in groundwater hydrology. in Fritz, P., Fontes, J. Ch. (eds) Handbook of Environmental Isotope Geochemistry. Vols. 1. Elsevier: New York, 75-140.

Freeze, R.A. and Cherry, J.A., 1979, Groundwater. Prentice-Hall: New Jersey, 604 pgs.

Frink, J.W. and Kues, H.A., 1954, Corcoran clay-a Pleistocene lacustrine deposit in San Joaquin Valley, California, AAPG Bulletin, 38, 2357-2371.

Gilliom, R.J., and others, 1988, Preliminary assessment oif sources, distribution, and mobility of selenium in the San Joaquin Valley, California. USGS Water Resources Investigations Report 88-4186, 129 pgs.

Glass, R.L., 1981, Groundwater resources of the Tassajara area, Contra Costa County, California. U.S. Geol. Surv. Open File Report, 62 pp.

Hem, J.D., 1985. Study and interpretation of the chemical characteristics of natural water. U.S. Geol. Surv., Water Supply Pap. No. 2254, 263 pp.

Henneman, K.R., 1990, Initial groundwater evaluation. Report prepared for the City of Brentwood, Kenneth R. Henneman, Water Resources Consultant, 17 pgs.

Hübner, H., 1986, Isotope effects of nitrogen in the soil and biosphere. in Fritz, P., Fontes, J. Ch. (eds) Handbook of Environmental Isotope Geochemistry. Vols. 2. Elsevier: New York, 361-425.

Ingraham N.L., Taylor B.E., 1991, Light stable isotope systematics of large-scale hydrological regimes in California and Nevada. Water Resources Research, 27, 7790. 
Mook, W.G., 1980, Carbon-14 in hydrogeological studies. in Fritz, P., Fontes, J. Ch. (eds) Handbook of Environmental Isotope Geochemistry. Vols. 1. Elsevier: New York, 49-74.

Nolte and Associates, 1992, City of Brentwood Infrastructure Master Plan Reports, Element: Flood Control and Drainage, Vol. 1 Draft report.

Page R.W., 1986, Geology of the fresh groundwater basin of the Central Valley, California, with texture maps and sections. USGS Professional Paper 1401-C. 54 pp.

Redwine, L.E., 1972. The Tertiary Princeton submarine valley system beneath the Sacramento Valley, California. Ph.D. Dissert., University of California, Los Angeles, 480 pp.

Snyder, R.L., Hanson, B.R., Coppack, R., 1986, How farmers irrigate in California. Cooperative Extension Univ. Calif. Div. of Ag. and Nat. Res., Leaflet 21414, 4 pgs.

Sorenson, S.K., 1981, Chemical quality of groundwater in San Joaquin and part of Contra Costa Counties, California. USGS Water Resources Investigations Report 81-26, 32 pgs.

Stephany, P.W., et al., 1989, Nitrate and agriculture in California. California Department of Food and Agriculture, Nitrate Working Group, 66 pp.

Taylor, R.E.; Long, A.; Kra, R.S. (eds), 1992, Radiocarbon After Four Decades, An interdisciplinary Perspective. Springer-Verlag: New York, 596 pgs.

Teeri, J.A. and Stowe, L.G., 1976, Climatic patterns and the distribution of $\mathrm{C}_{4}$ grasses in North America. Oecologia, 23, 1-12.

Thomasson, H.G., Olmsted, F.H. and LaRoux, E.F., 1960, Geology, water resources and usable groundwater storage capacity of part of Solano County, California. U.S. Geol. Surv., Water Supply Pap. No. 1464, 693 pp.

Vogel, J.C., 1967, Investigation of groundwater flow with radiocarbon. In: Isotopes in Hydrology. IAEA, Vienna, 355-369. 
Walker, F.W., Parrington, J.R., Feiner F., 1989, Nuclides and Isotopes. General Electric Co. Nuclear Energy Operations: San Jose, Calif., 57 pgs.

Welch, L.E., 1977, Soil survey of Contra Costa County, California. United States Dept. of Agriculture, Soil Conservation Service, $122 \mathrm{pp}$. 


\section{Figure Captions}

Figure 1. Location map of the Brentwood region with well locations. Over 90 samples were collected for the isotope study.

Figure 2. Generalized surface soil map of the Brentwood region where white areas represent clay loam soils and shaded areas are clay soils. Note that the soil become more clay-rich on the eastern side of the Brentwood region. Data is from Welch (1977).

Figure 3. Secular changes in nitrate concentrations in the City of Brentwood municipal wells has resulted in shut down of 5 out of 7 wells due to their exceeding the EPA allowable limits.

Figure 4. Summary of the geological stratigraphy of the central portion of the Great Valley. Data is from DWR (1967).

Figure 5. Generalized geologic map of the west-central part of the Great Valley. Of notable importance is the occurrence of Plio-Pleistocene deposits (Tf) that host abundant groundwater supplies in many regions of the Valley. The exposure of these deposits is absent on the western edge of the Brentwood region, resulting in a lack of suitable recharge area for deeper groundwater of good quality.

Figure 6. 1982 groundwater levels in the Brentwood region show the regular southwest to northeast slope and inferred flow. A general gradient of 0.003 is used in this report.

Figure 7a. Contour map of the number of well drilling records in the Brentwood region on record at the Department of Water Resources. The most dense occurrence of wells is generally associated with the City of Brentwood area and along the Highway 4 corridor. 
Figure 7b. Contour map of average perforation levels in wells drilling records indicate that a general utilization of the $100-150 \mathrm{fbs}$ level is common throughout the region. Overall, the well depths reflect a general deepen from the west to the east that is most likely due to deepening of the permeable layers in the Brentwood region.

Figure 8a. Contour map of dissolved nitrate concentrations in wells sampled for the isotope study. Analyses are performed with field color indicator strips and are not certified EPA results.

Figure 8b. Cross-section along the flow path $\left(A-A^{\prime}\right)$ and orthogonal to the flow path (BB'). Nitrates have penetrated to greater depths on the western side of the Brentwood area. The highest concentrations are observed in the shallowest groundwater.

Figure 9. $A \delta D-\delta^{18} O$ plot of Brentwood region groundwaters forms a mixing line between a pristine rain recharge component (circled data) and an agricultural recharge component at around $\delta^{18} \mathrm{O}=-9.2 \%$. The agricultural water is derived ultimately from the Sierra Nevada where stable isotope values of water are much lower, and subsequent evaporation cause a significant shift from the GMWL.

Figure 10a. Contoured $\delta^{18} \mathrm{O}$ values of well waters sampled for the isotope study. Groundwater between -7.0 and $-6.5 \%$ represents pristine groundwater recharged by local rain. Values more negative than $\mathbf{- 7 . 0 \%}$ represent mixing of agricultural irrigation water that originated from Sierra Nevada sources. Note that the areas with the most irrigation water recharge are essentially the same as the high $\mathrm{NO}_{3}$ areas of Fig. 8a. 
Figure 10b. Cross-sectional view along the same lines as Fig. 8b. Note that the agricultural recharge water has a similar distribution as the higher $\mathrm{NO}_{3}$ water. The average vertical penetration of irrigation water is between $100-150 \mathrm{ft}$ below the surface.

Figure 11. The measured $\mathrm{NO}_{3}$ concentrations of the groundwater compared to their $\delta^{18} \mathrm{O}$ values show that both result from agricultural irrigation water recharge.

Figure 12. Piper plot of Brentwood region groundwaters define a uniform chemical type of $\mathrm{CaNa}-\mathrm{HCO}_{3} \mathrm{Cl}$. The higher TDS levels (circles) in the groundwaters are associated with a shift in the $\mathrm{Cl}$ direction.

Figure 13. Application of agricultural water at rates $>10$ times the natural precipitation rates results in a flushing of soluble salts in the soil of the Brentwood region, resulting in a factor of two increase in EC (proportional to dissolved solids) in the agricultural recharge water relative to the pristine water.

Figure 14. The leached soluble salts from agricultural water application are likely $\mathrm{Cl}$-rich due to the higher dissolved $\mathrm{Cl}$ in the agricultural recharge water relative to the pristine water.

Figure 15. Dissolved oxygen decreases in groundwater due to anoxic chemical environments. Microbial utilization is commonly considered the mechanism of DO depletion. With the depletion of DO, increases in dissolved iron and manganese occurs, resulting in poor water quality. Much of the deeper groundwater in the Brentwood region may all have this common problem. 
Figure 16. Diagram illustrating flow rate calculations of the Brentwood region groundwater.

Figure 17. The applied irrigation water over time shows a near linear increase over time. A conservative steady-state quantity was derived, though, for the mass balance model at 37,550 acre-ft/yr and used for the years 1973-1994 (see text).

Figure 18. The record of groundwater pumped by the ECCID shows that an approximate 25\% decrease occurred between 1950 and 1972. Extrapolation of groundwater pumped from 1935 to 1949 and 1973-1994 yielded an estimate of 4500 acre-ft/yr.

Figure 19. Simple model showing the decrease in recharge available for sustaining a safe yield. An estimated $90 \%$ decrease in recharge occurs when urban growth eliminates irrigation recharge and reduces recharge from precipitation. For the model the total acreage remains the same and a one-for-one replacement of agricultural land for urban land occurs as the population grows. Line (a) is modeled for the total 17,000 acres in the Brentwood region, although only approximately half of this land is slated for urban development. Line (b) is modeled just for the $\sim 8000$ acres slated for urban development and ignores contributions from outlying regions.

Figure 20a. Reconstruction of groundwater flow field in the Brentwood region based on ${ }^{14} \mathrm{C}$ ages contoured in the figure. Groundwater in the western and central parts of the region are less than 2000 years old, flowing eastward at velocities around $5 \mathrm{ft} / \mathrm{yr}$. Low permeability areas to the east probably forced much of the groundwater through lateral channelized zone, toward the surface where it was evapotranspirated, or down to deeper depths. 
Figure 20b. The cross sectional view looking north constructs the general subsurface permeability based on ${ }^{14} \mathrm{C}$ ages. Recharge appears rapid and deep in the western part of the basin, and groundwater flow eastward into semi-confined permeable aquifers that appear well interconnected. 


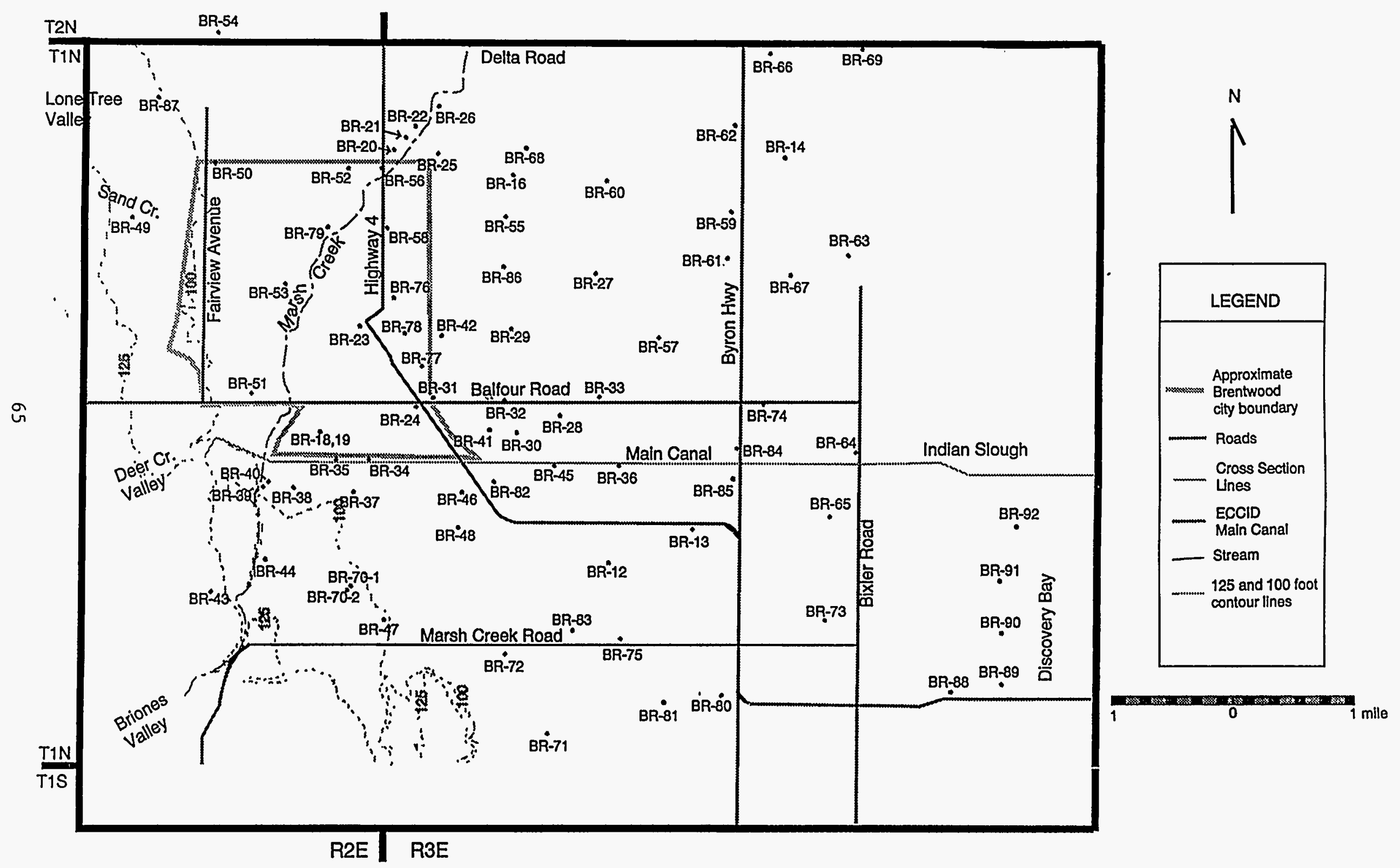

Figure 1 


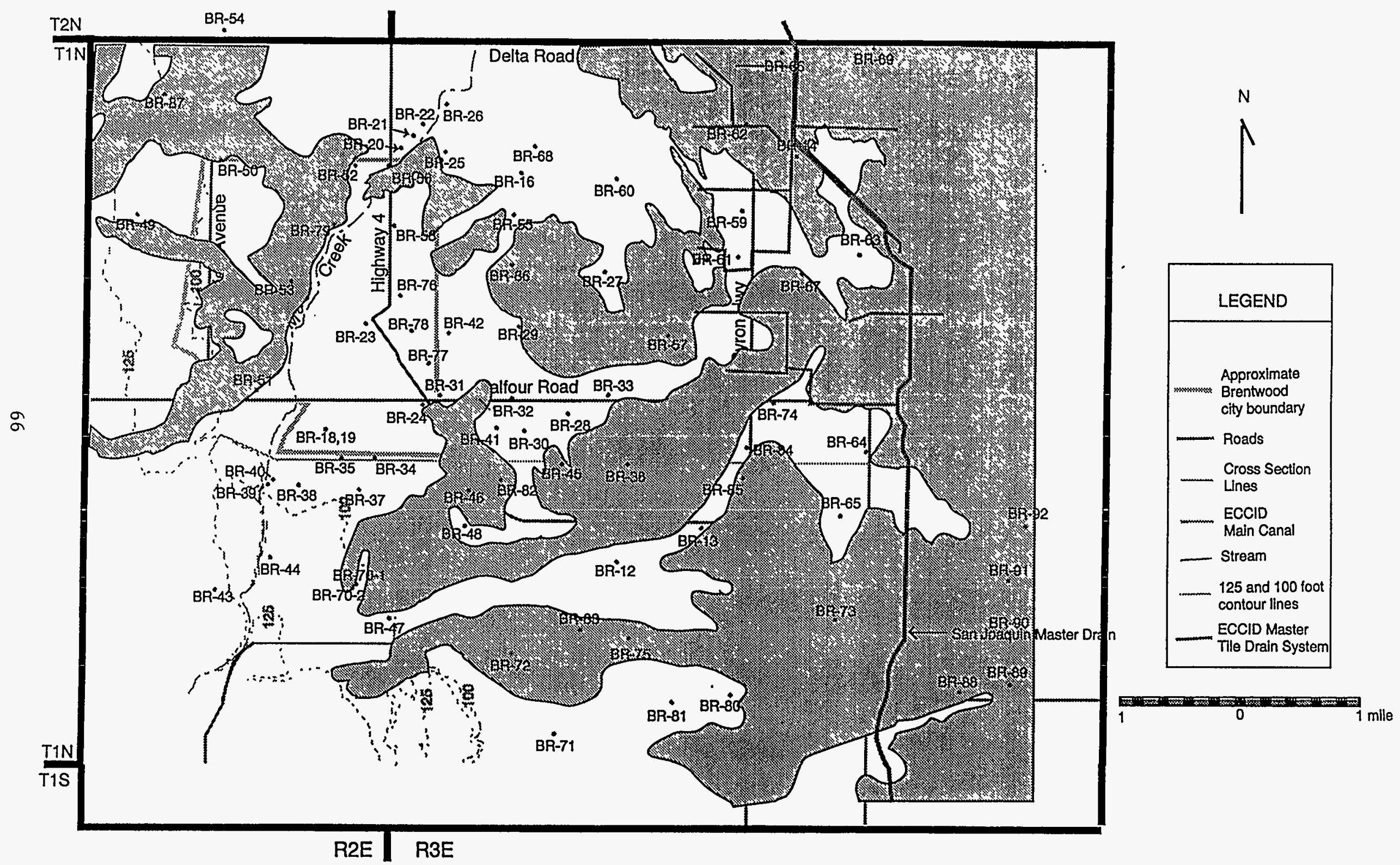

Figure 2 


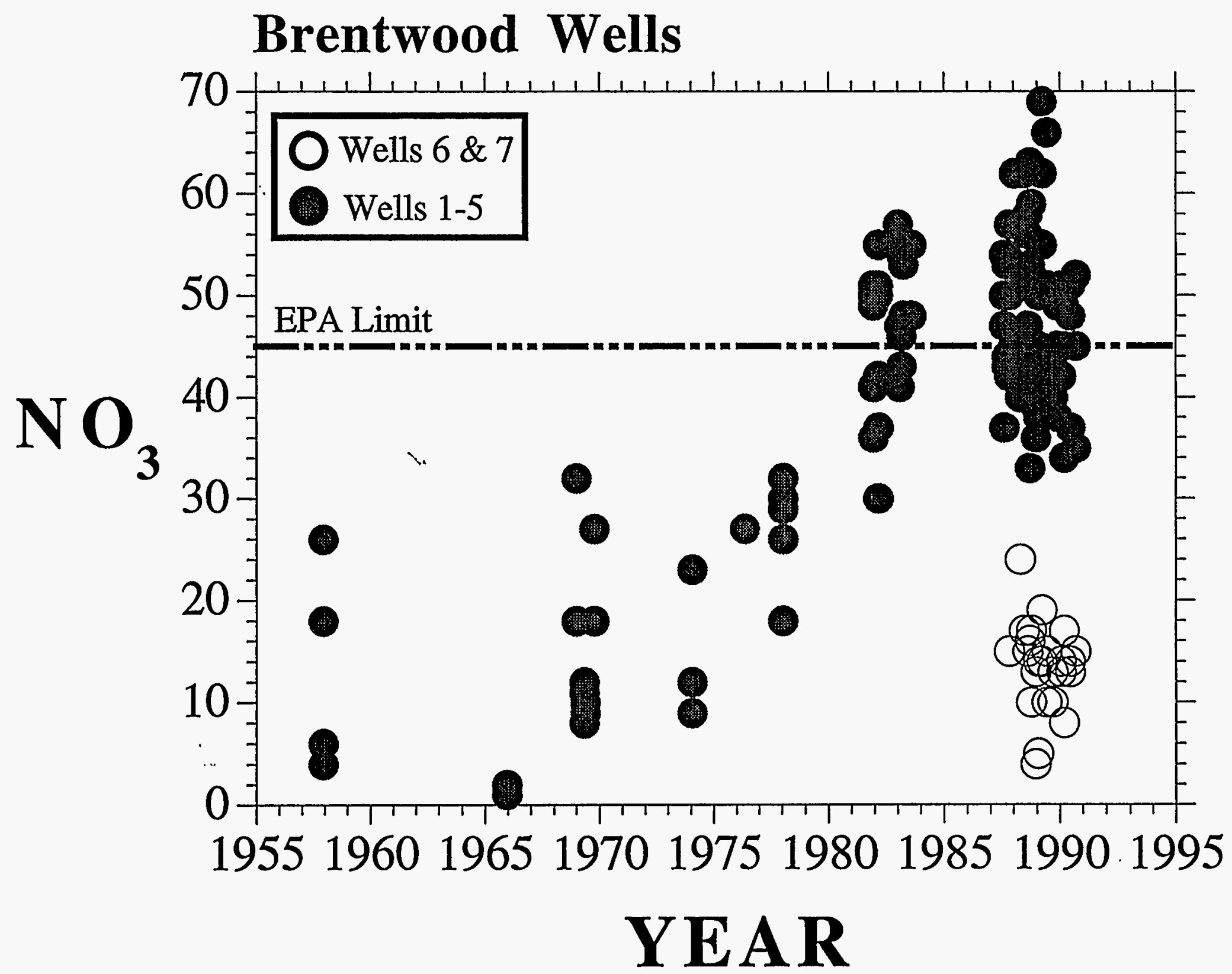

Figure 3 
GENERALIZED STRATIGRAPHIC COLURA

OF SAN JOAQUIN COUNTY

WITH WATER BEARING CHARACTERISTICS

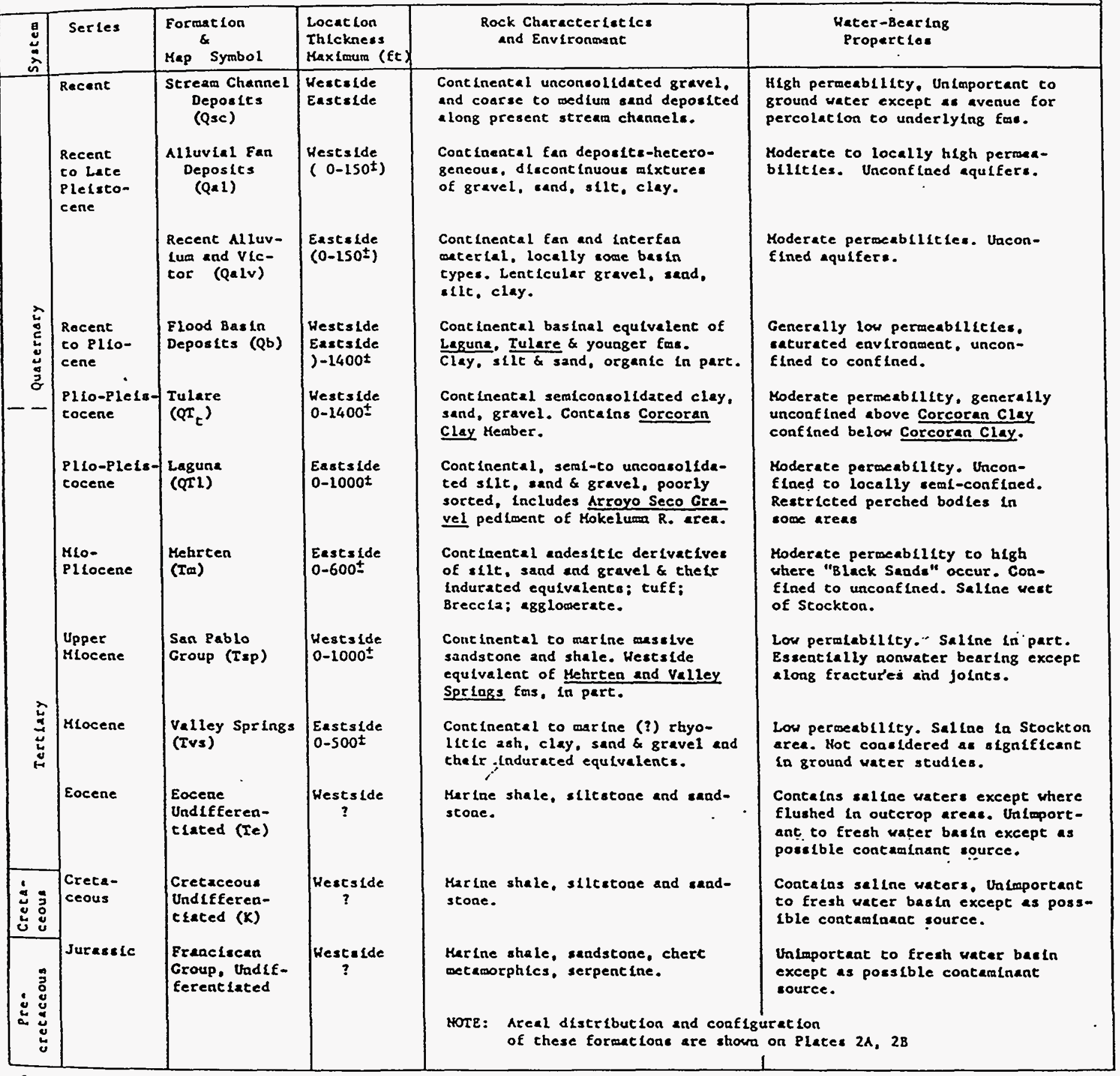

? Indetermalnate In Outcrop 


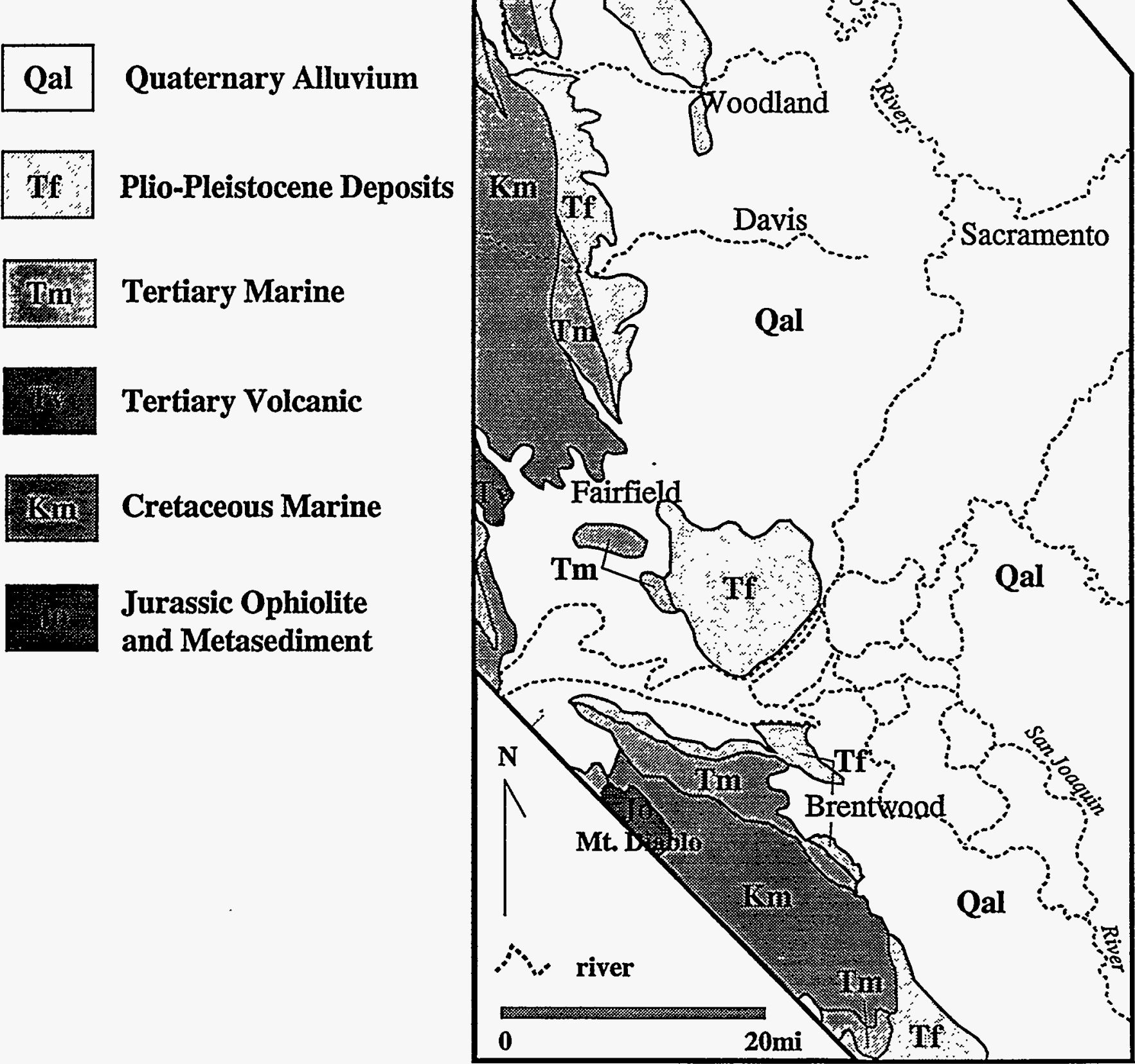



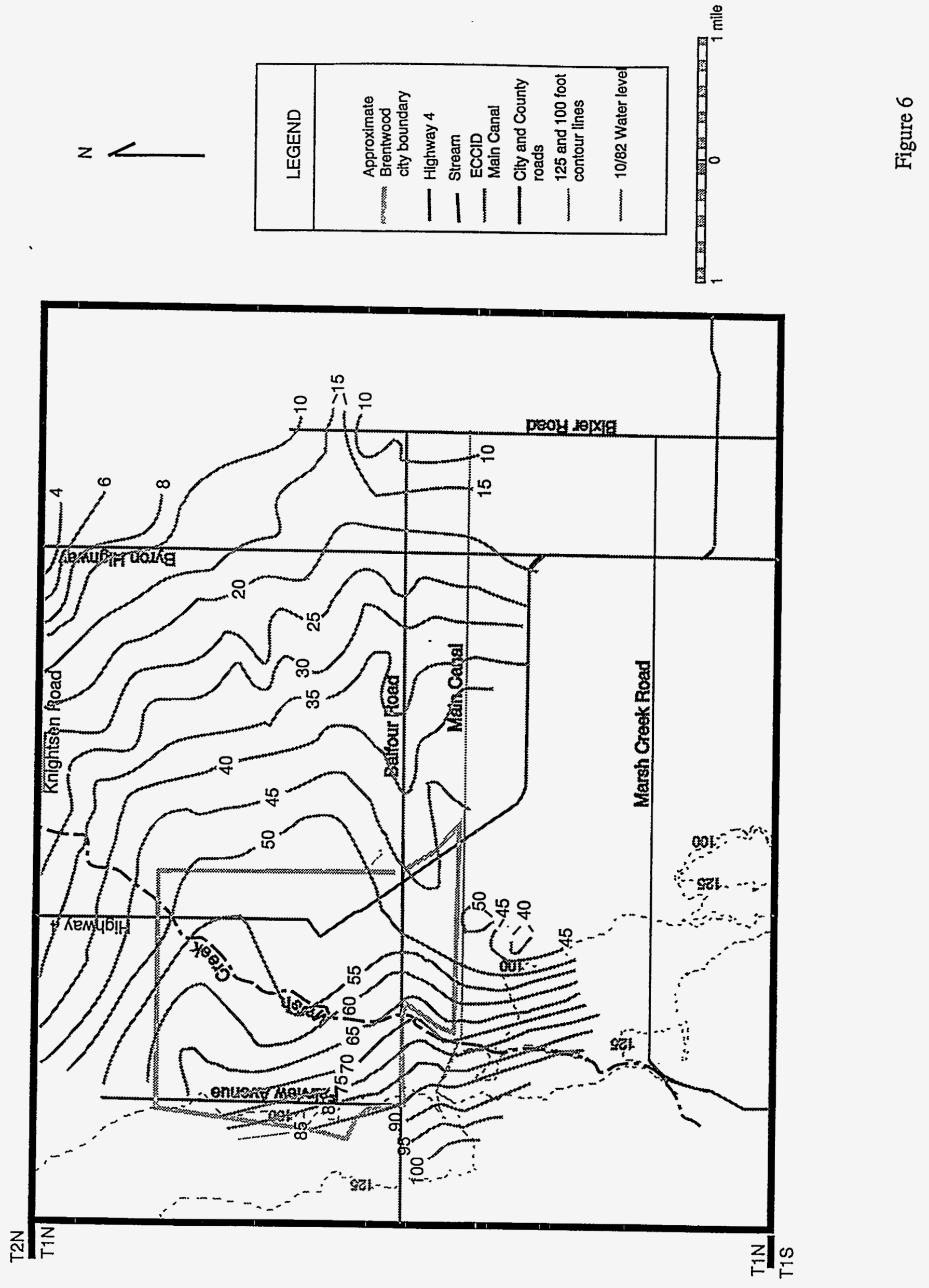


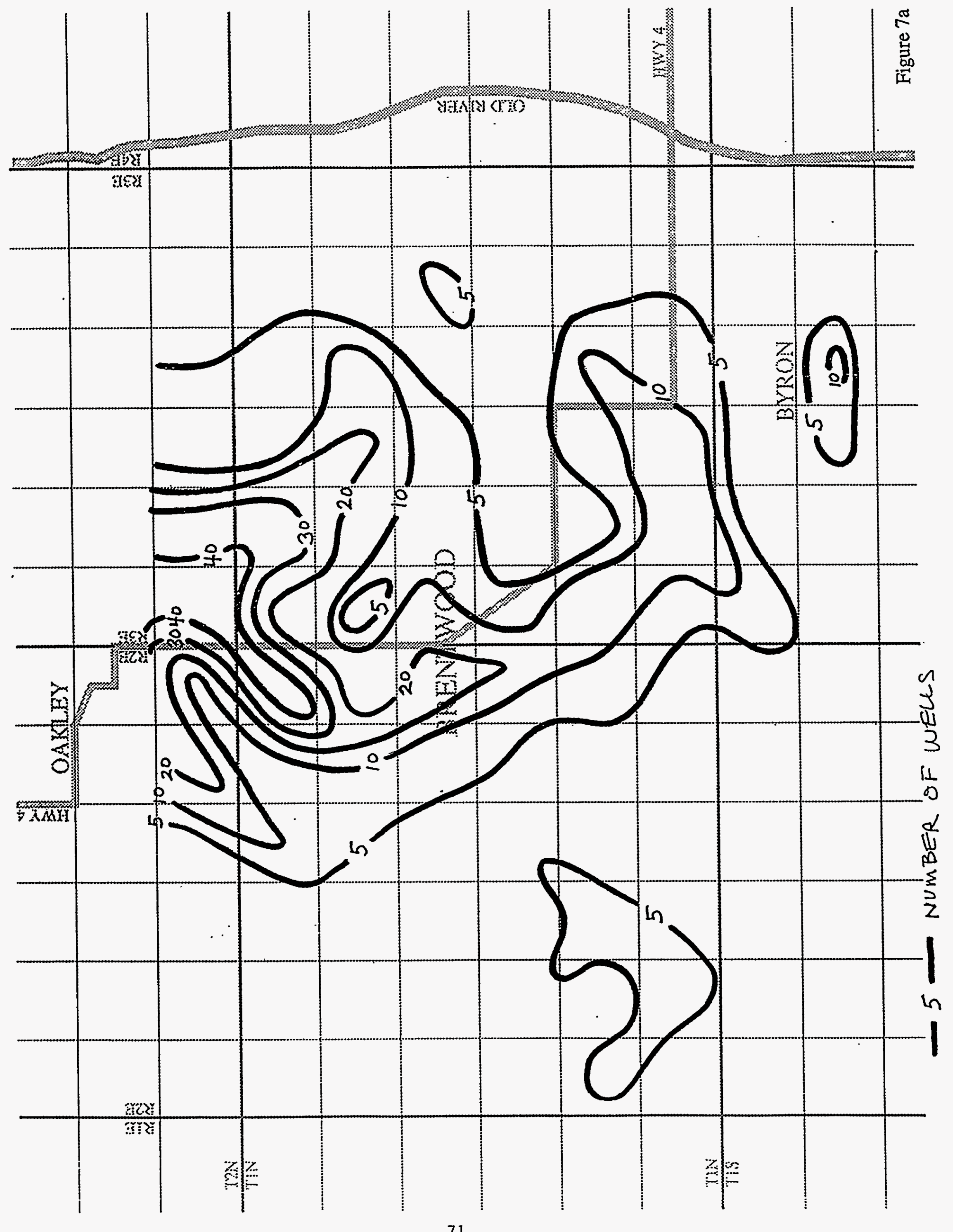




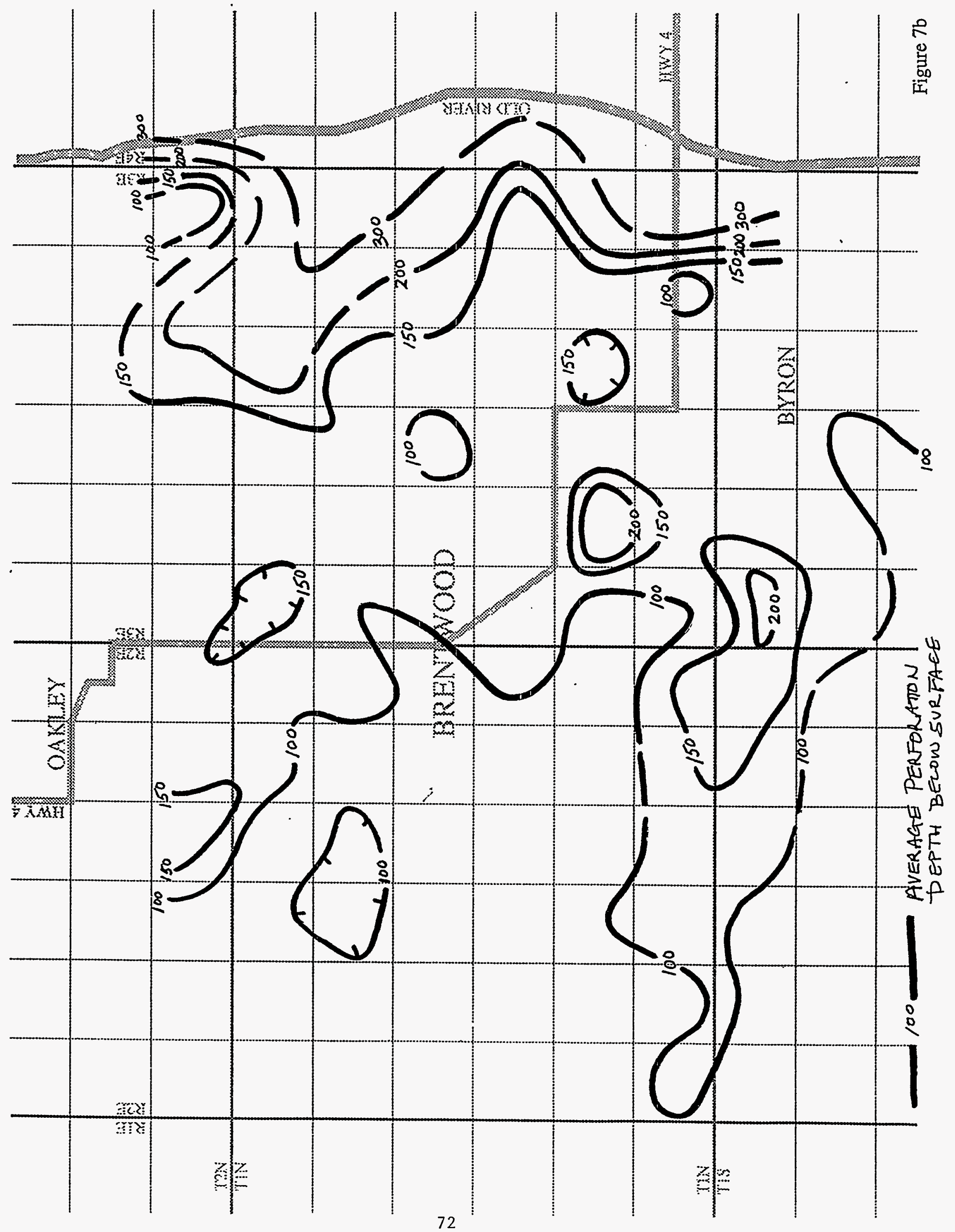



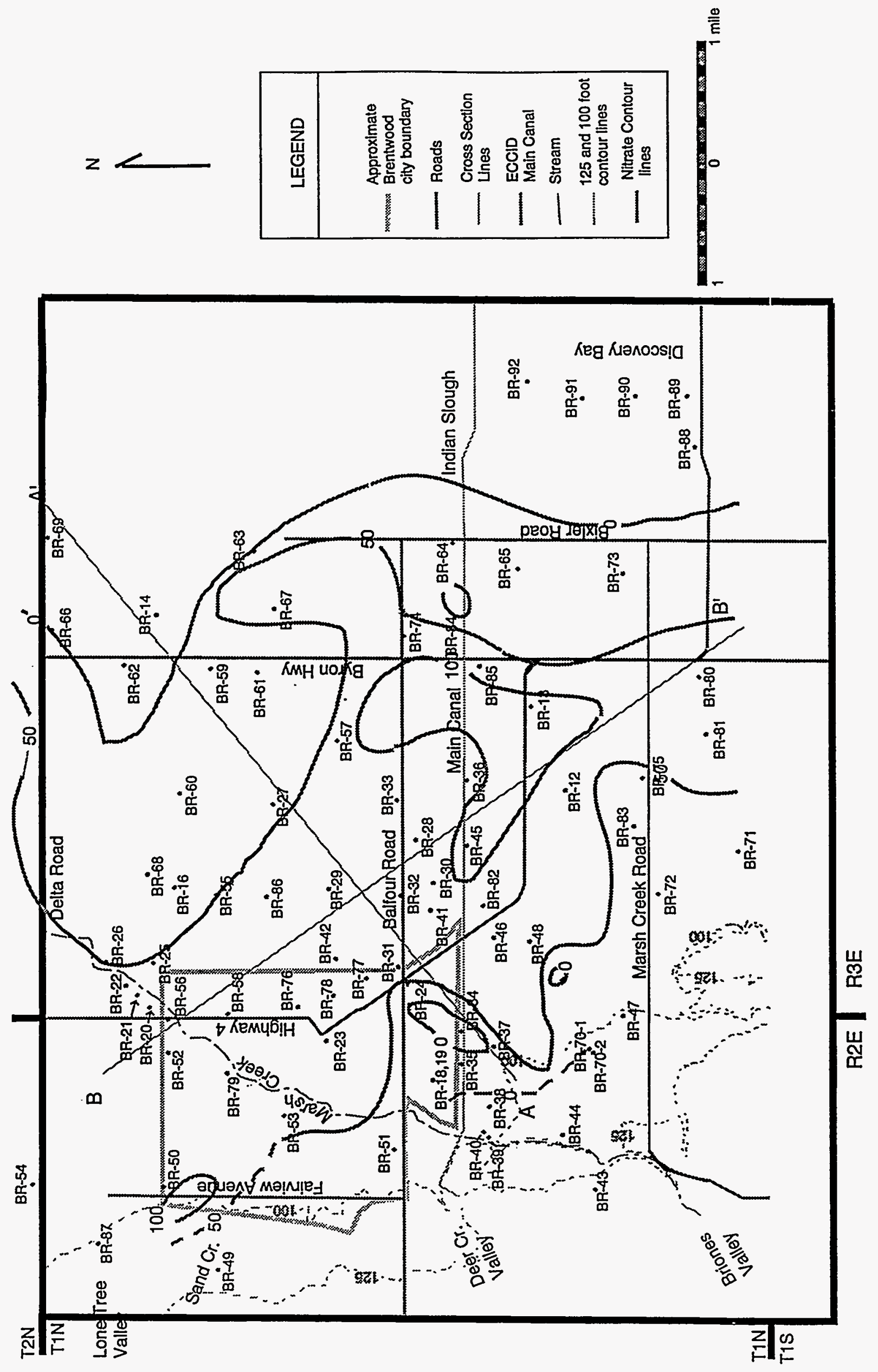

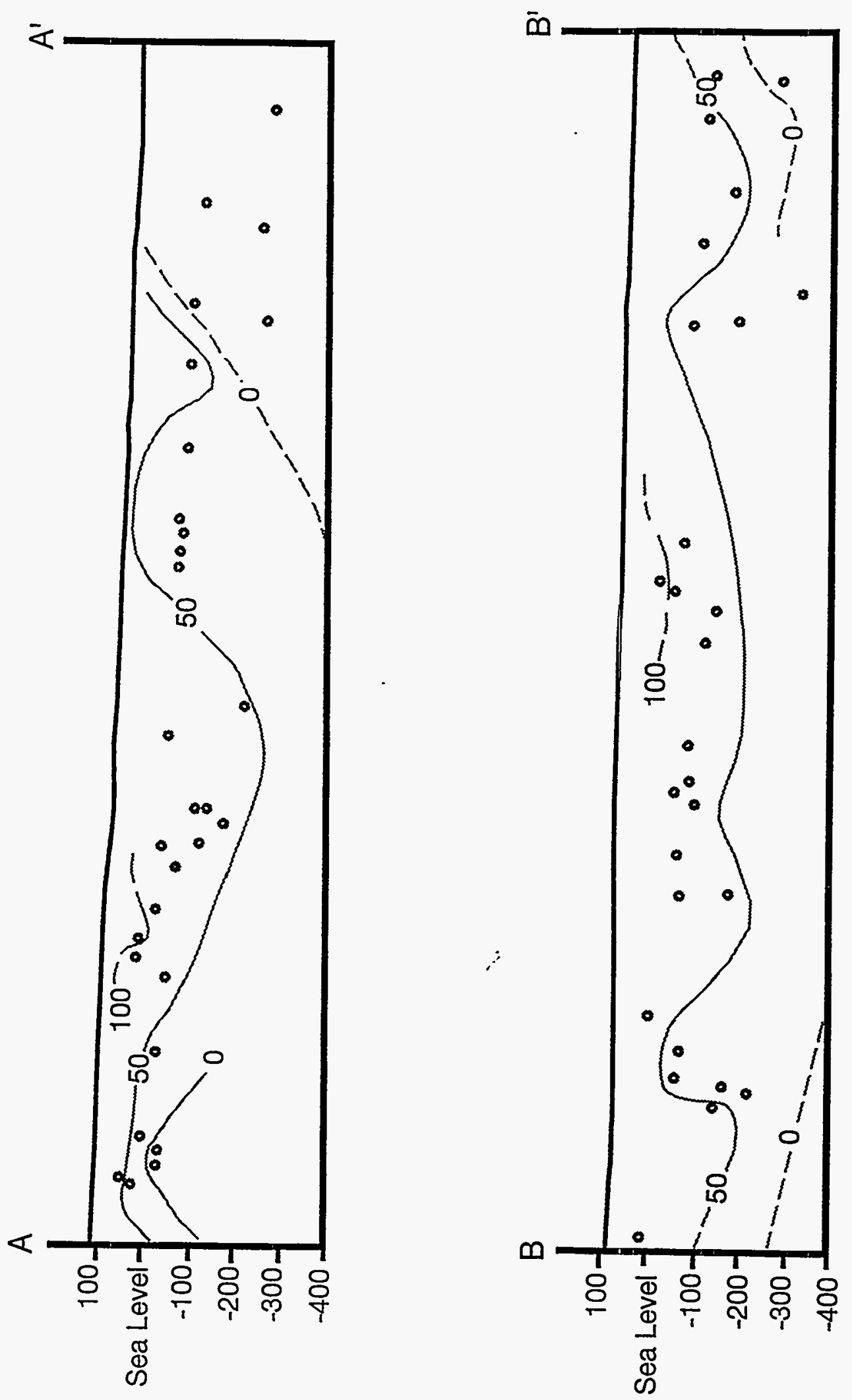

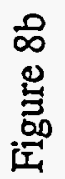




\section{Brentwood Region}

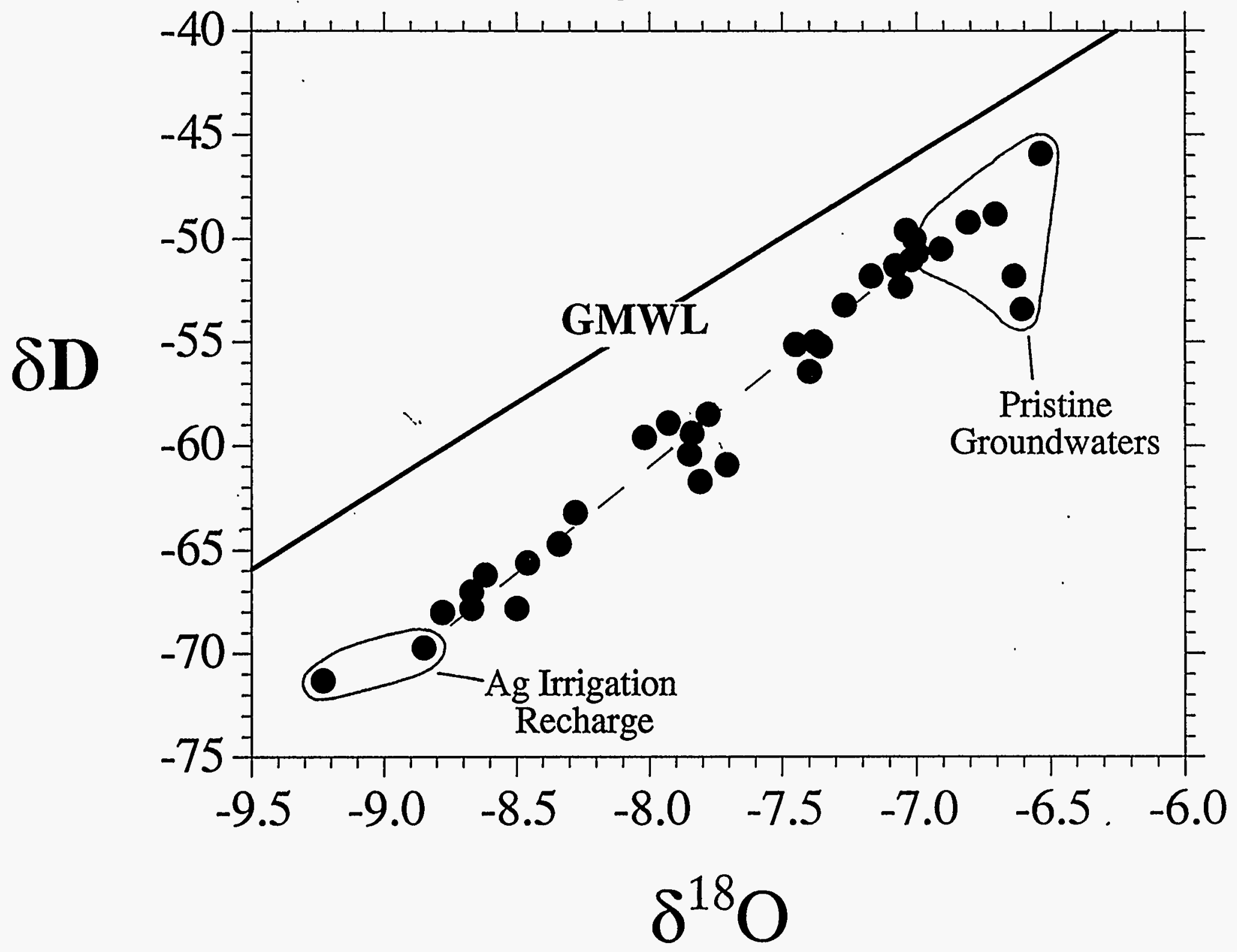

Figure 9 


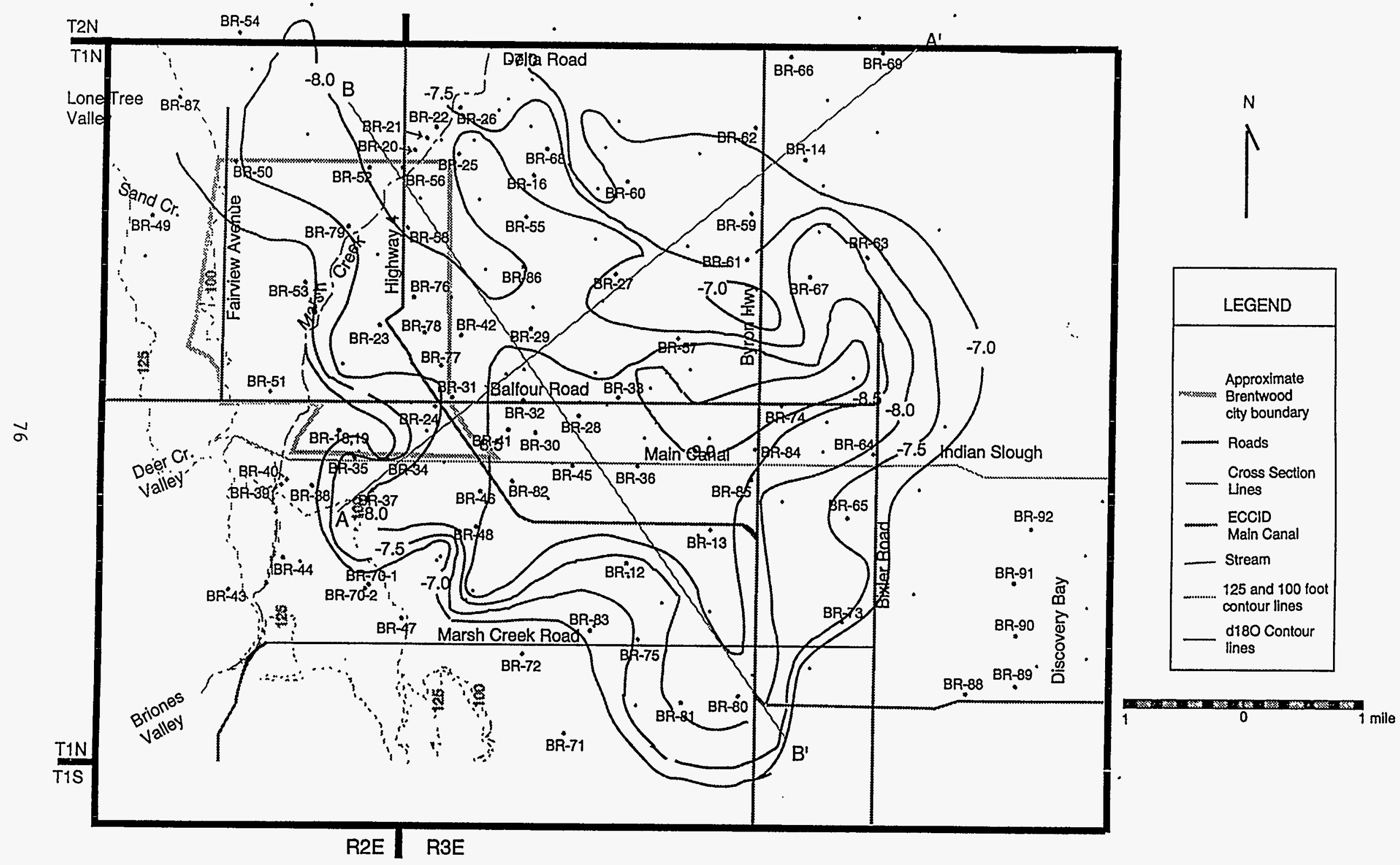

Figure 10a 

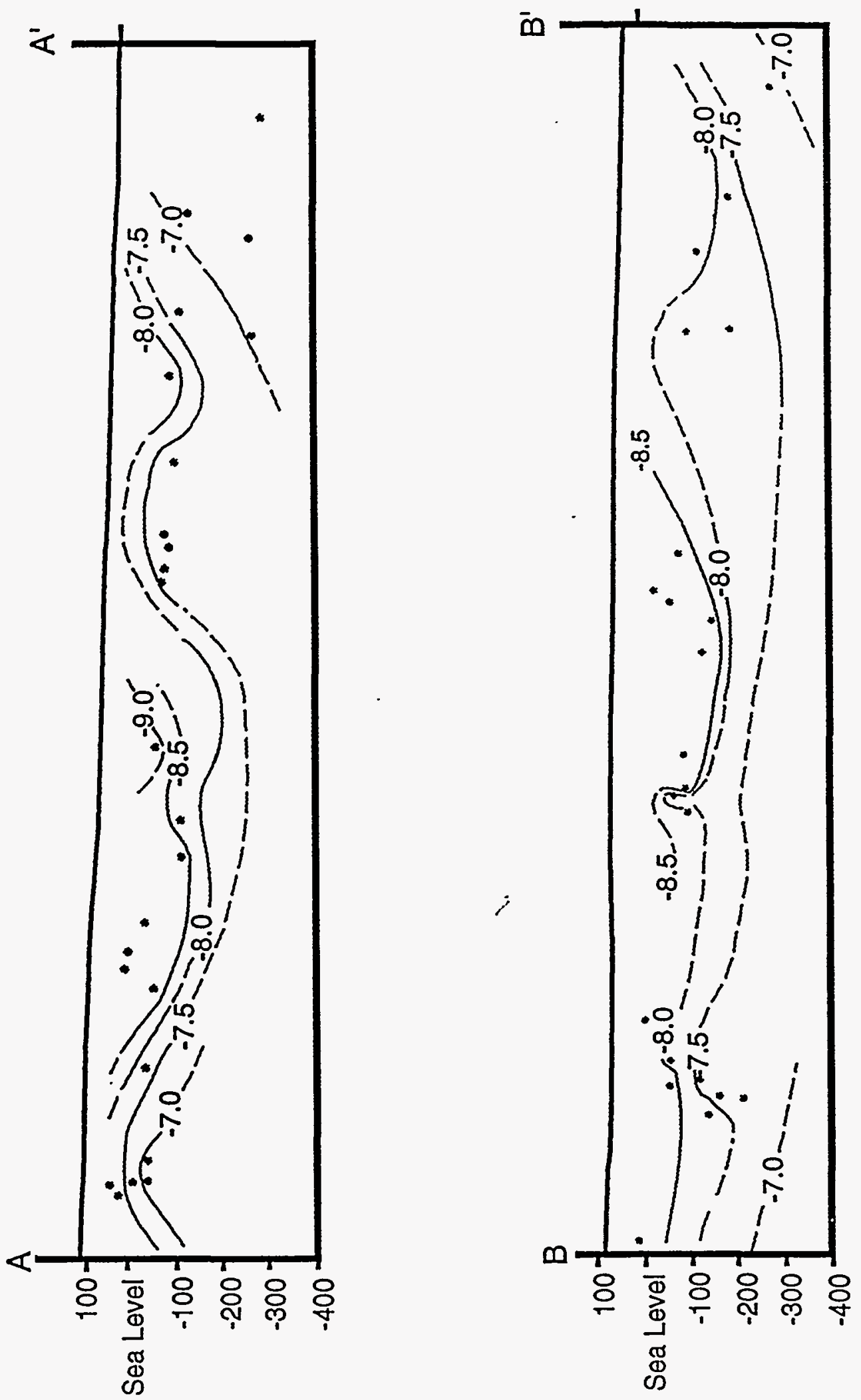

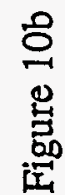




\section{Brentwood Region}

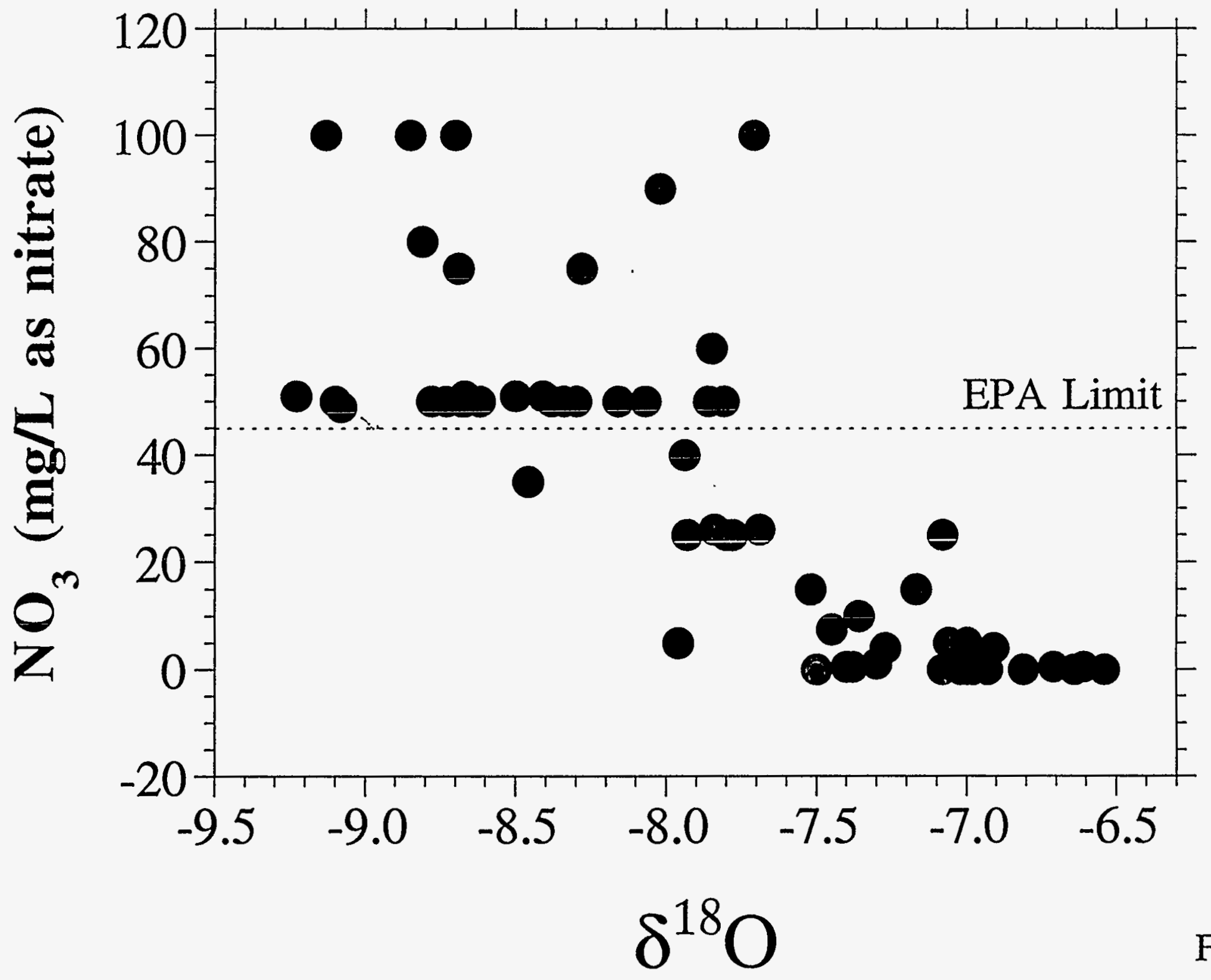

Figure 11 


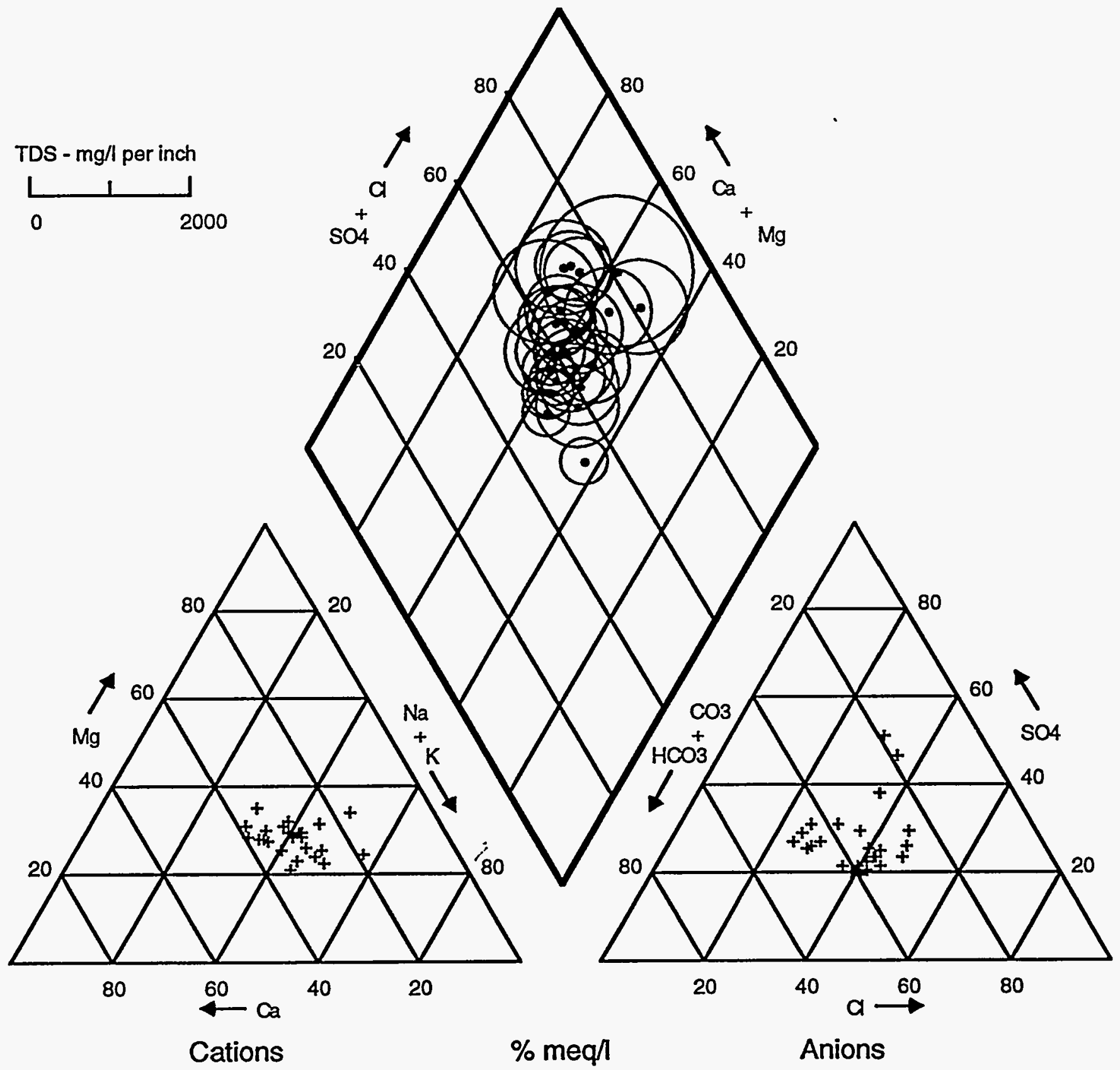




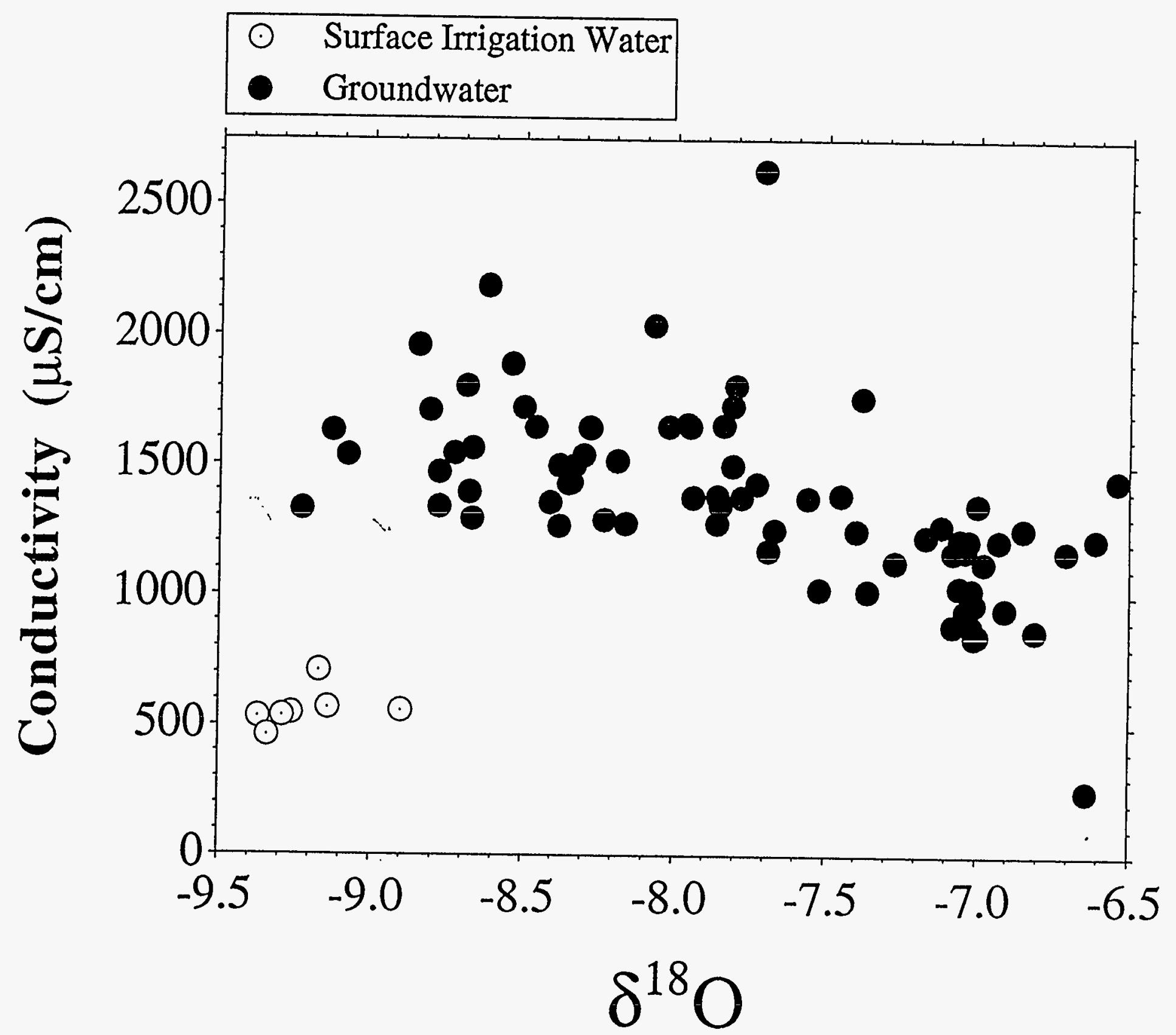

Figure 13 


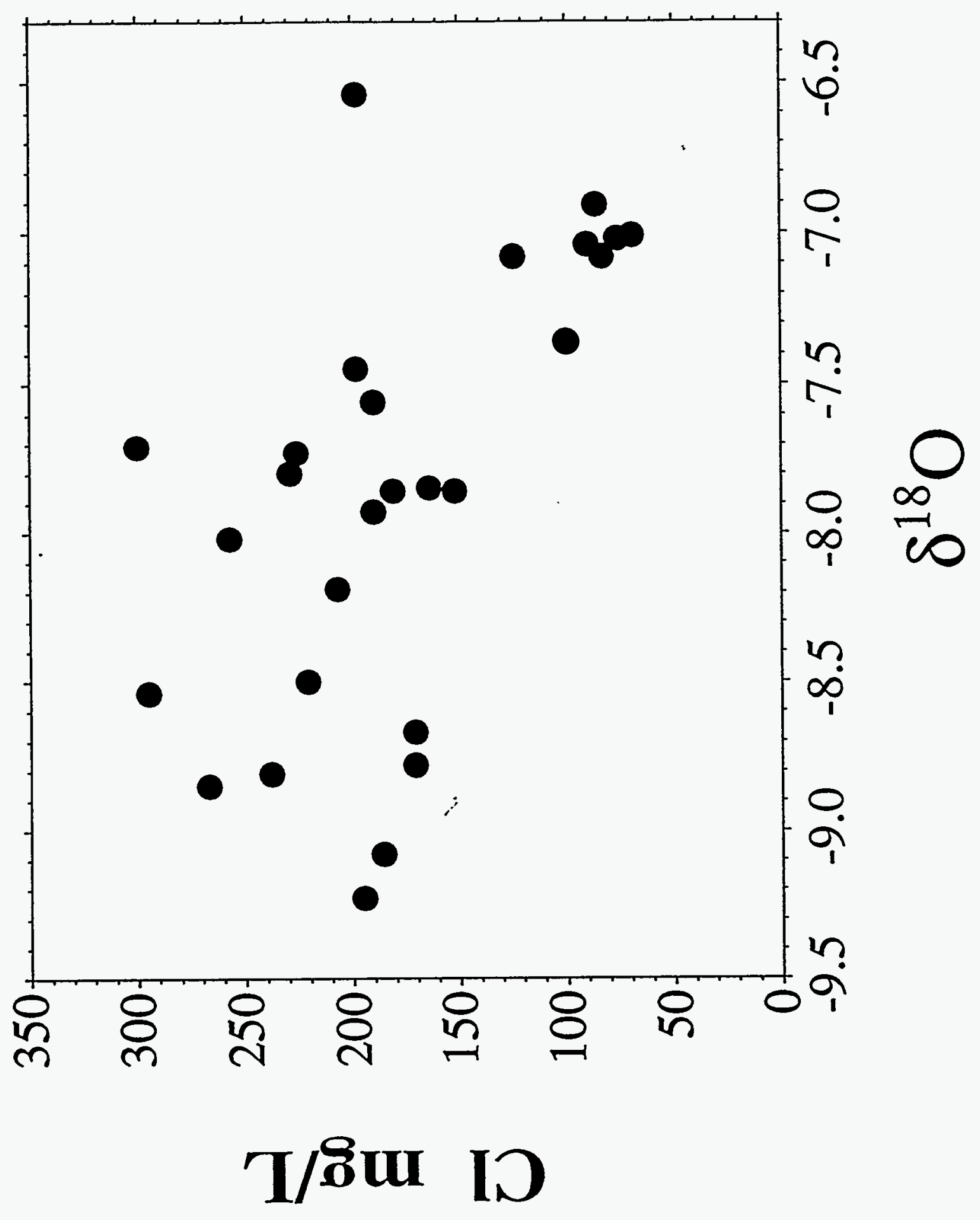




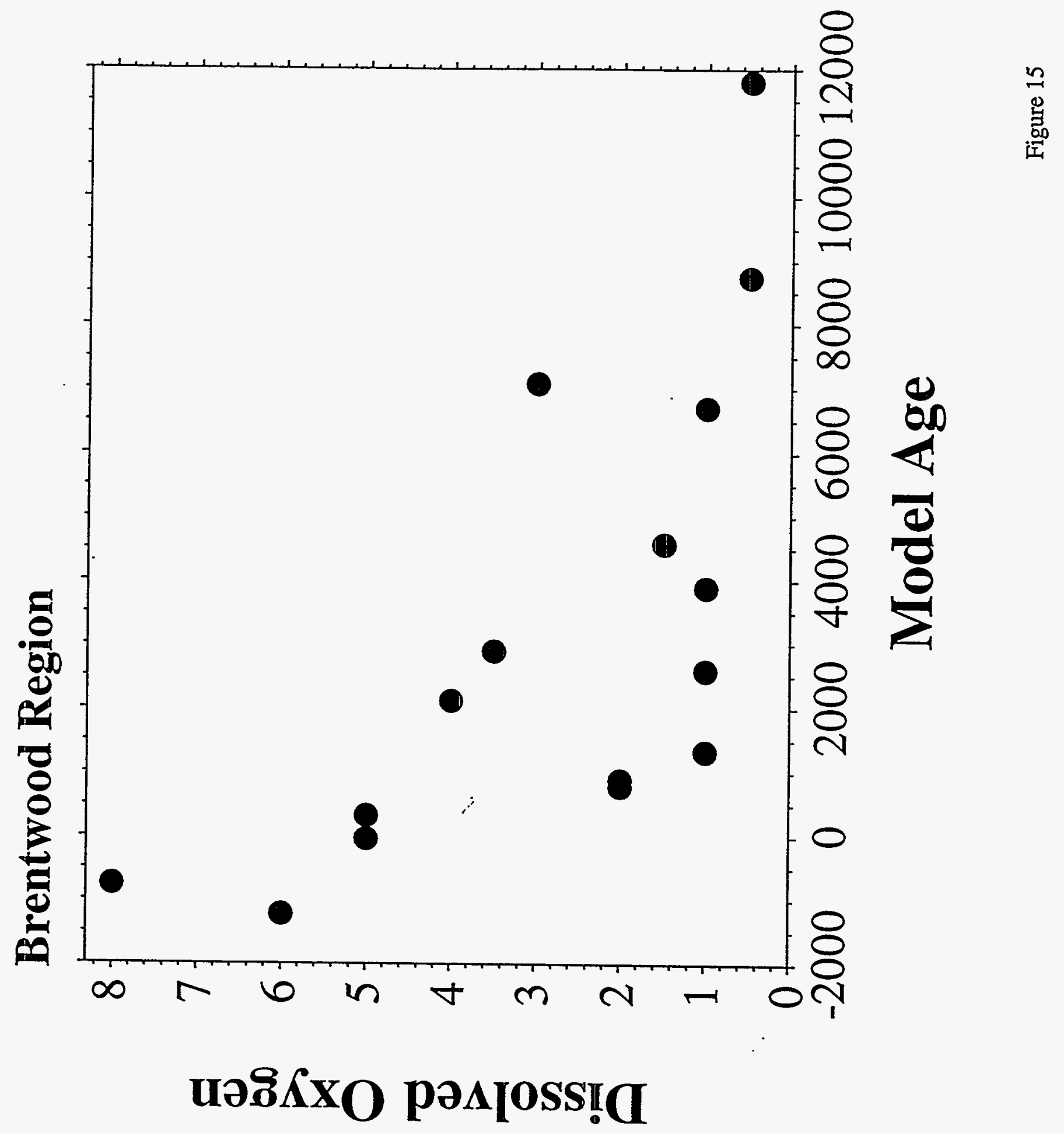


苟
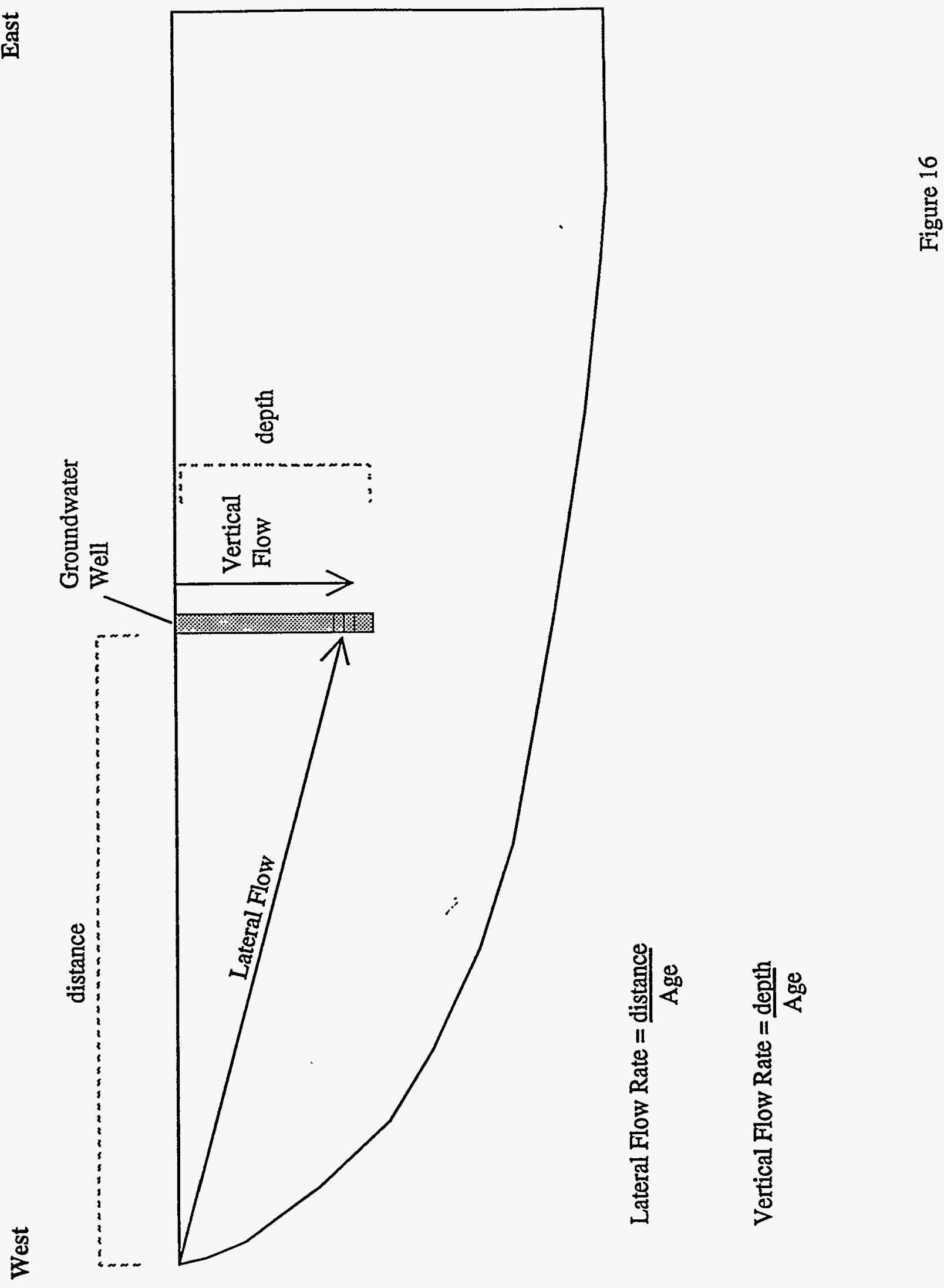

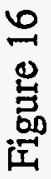




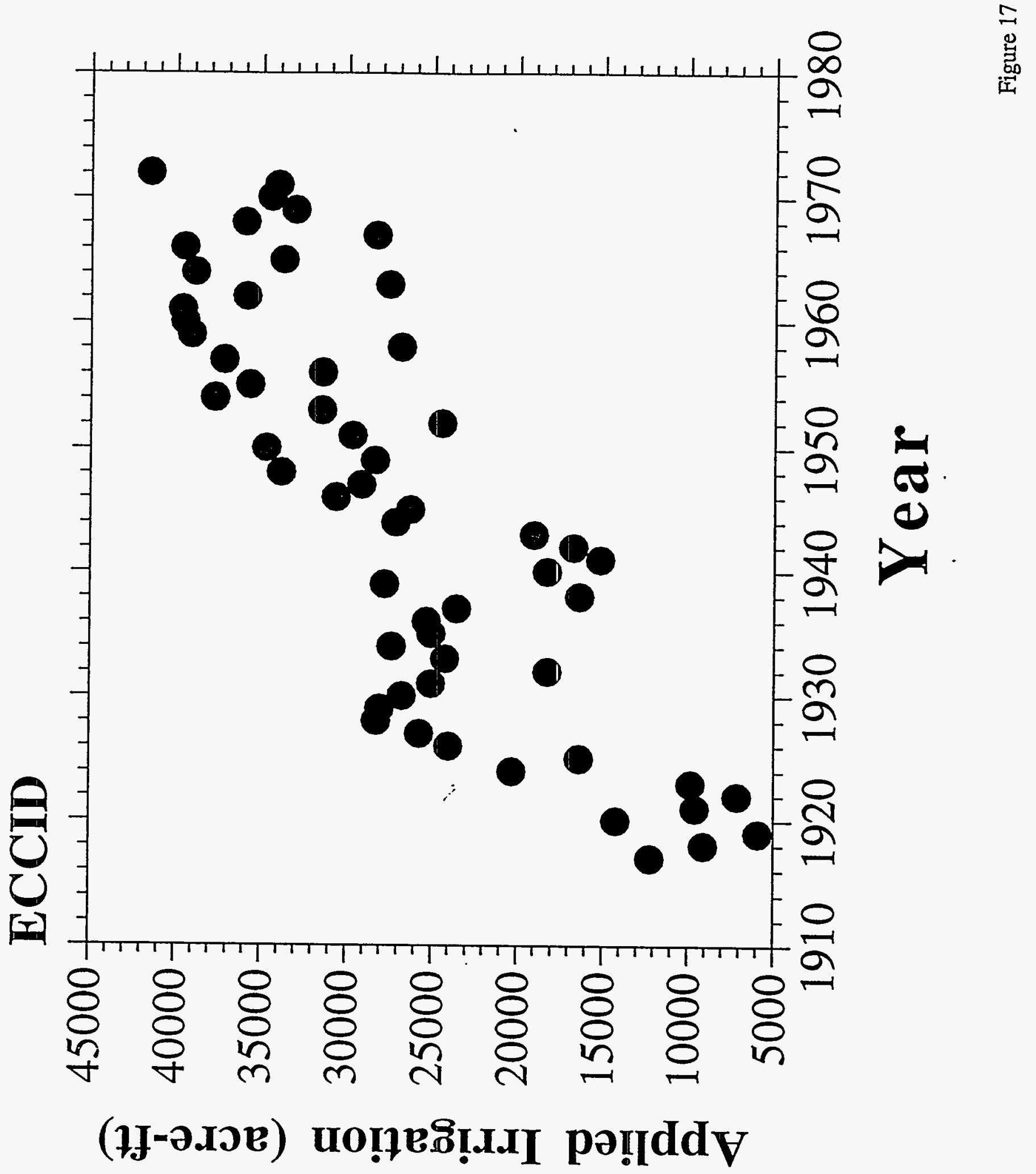




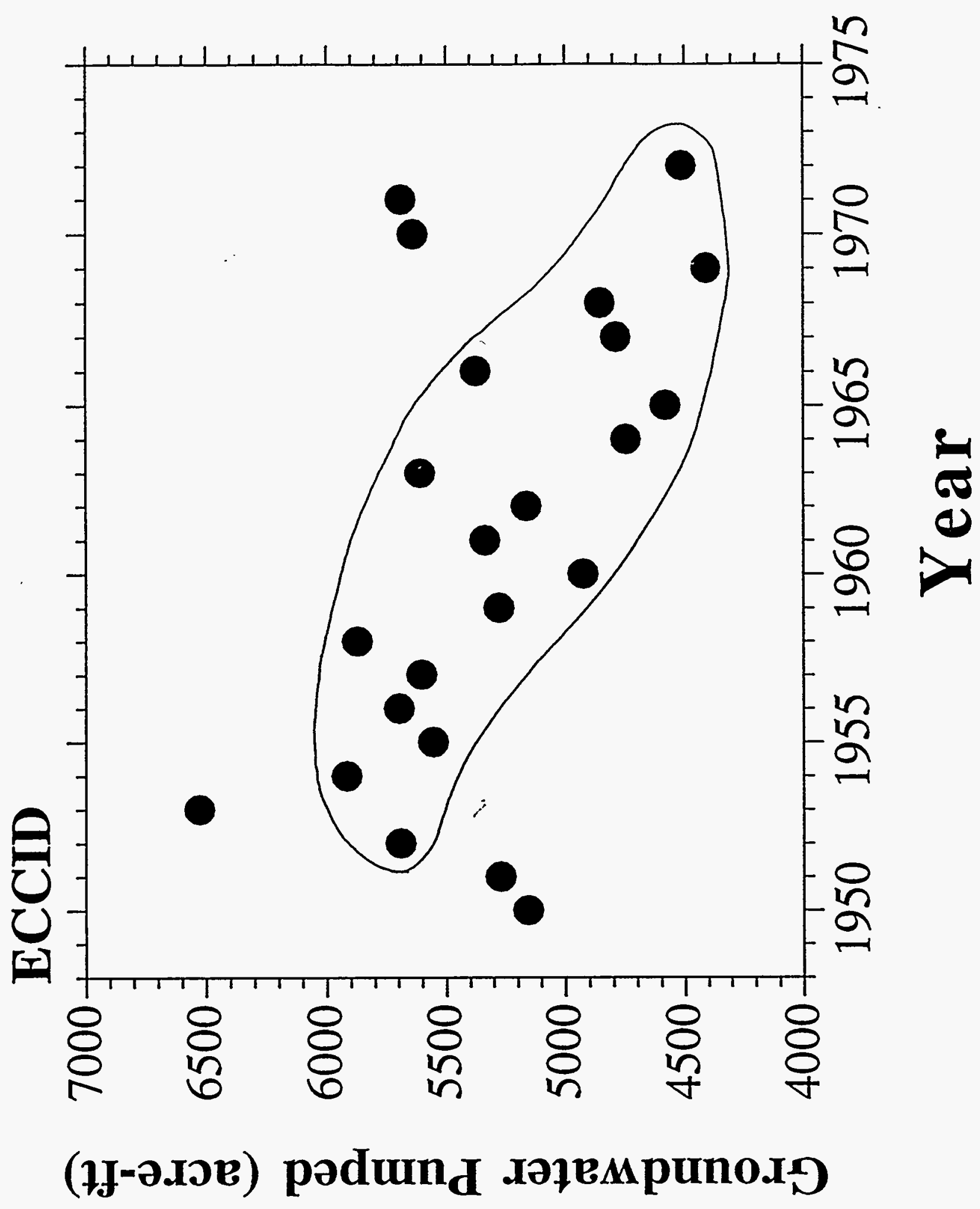




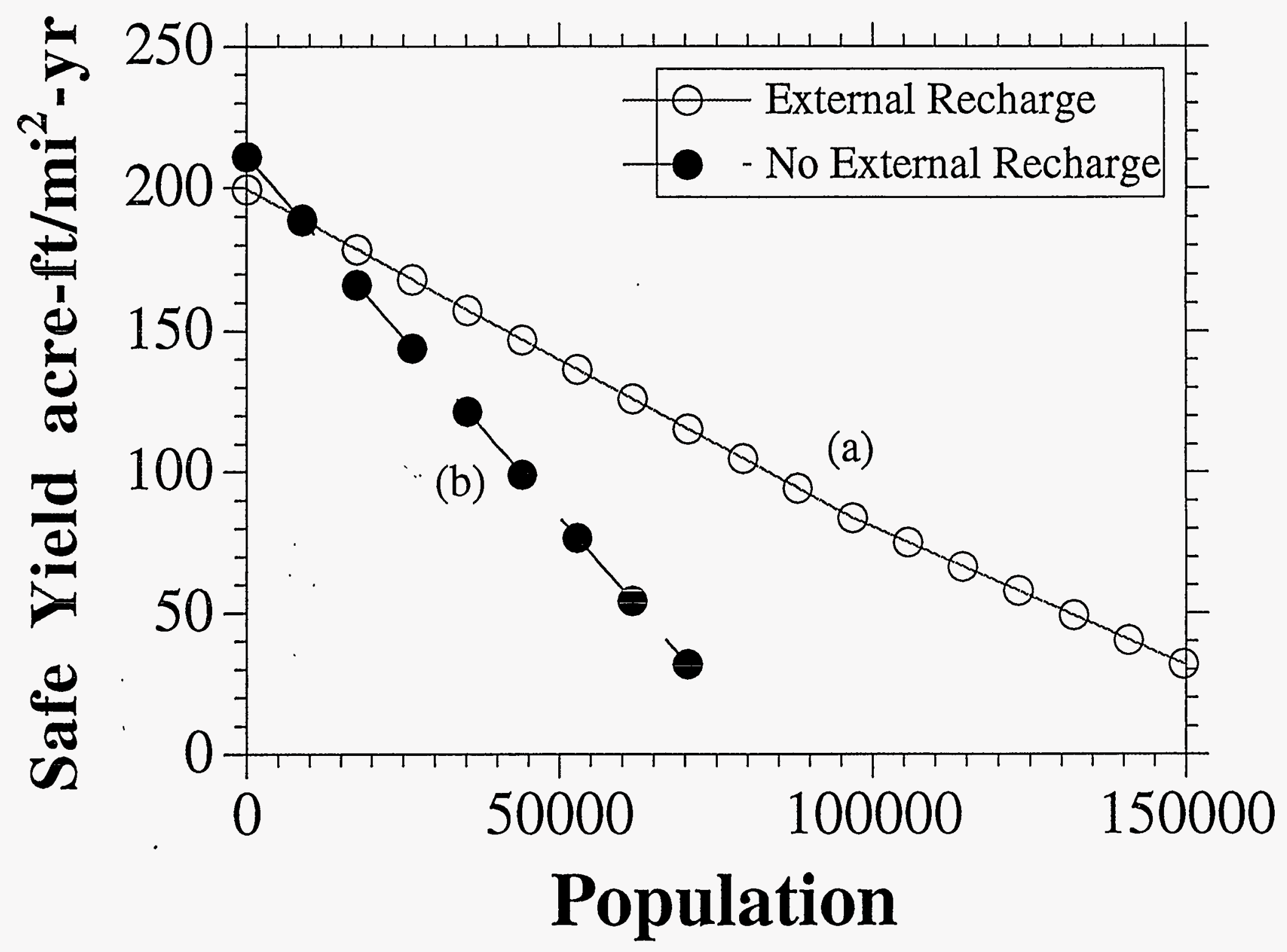

Figure 19 


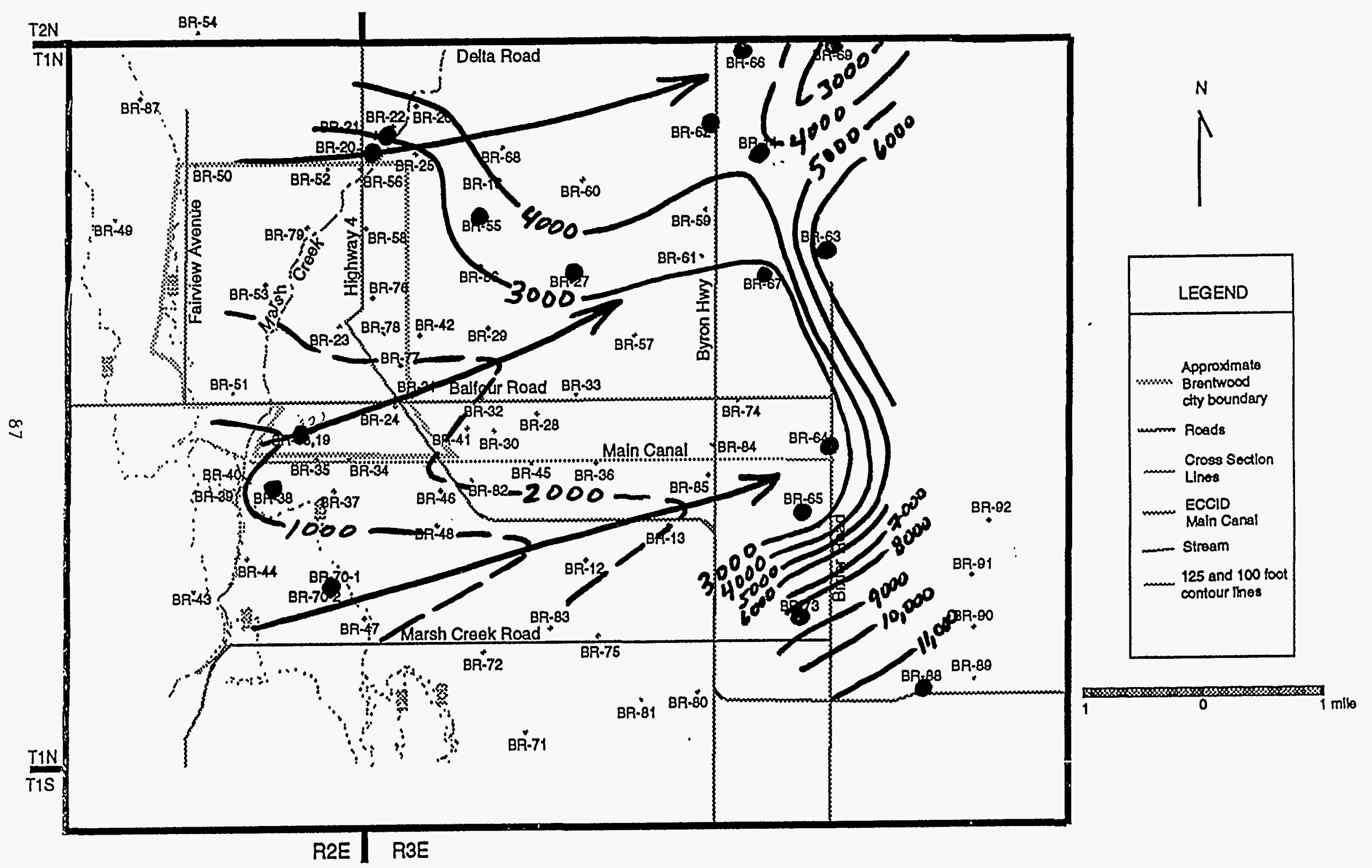

Figure 20a 


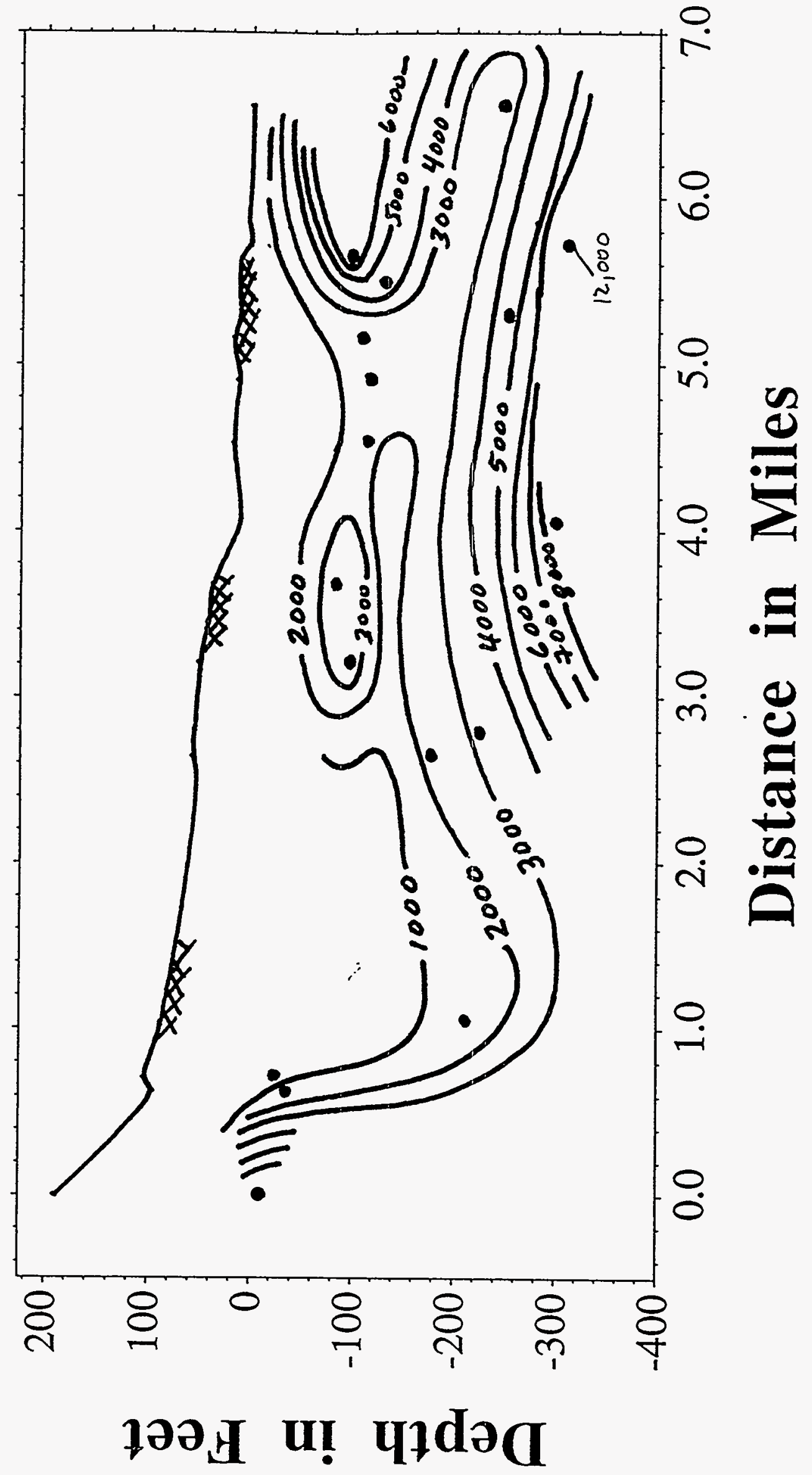


Table 1: Brentwood Region Samples

Sample Township/Range/ Perforation Depth Avgerage Sample/Well Well Age Section (fbs)

Perforation (fbs) Type

Termco Oil Well

\begin{tabular}{|c|c|c|c|}
\hline BR-1* & 1N3E30 NWSW & & \\
\hline BR-2 * & 1N3E22 SWNE & & \\
\hline BR-3 * & 1N3E22 SENE & & \\
\hline BR-4 * & 1N3E20 SENW & & \\
\hline $\mathrm{BR}-5 *$ & 1N3E21 SWNW & & \\
\hline BR-6 * & 1N3E21 SWNW & & \\
\hline $\mathrm{BR}-7$ ** & 1N3E3 SESE & & \\
\hline BR-8 & 1S3E2 NWNW & & \\
\hline BR-9 * & 1N3E16 SENE & & \\
\hline $\mathrm{BR}-10 *$ & 1N3E 7 NWNE & & \\
\hline $\mathrm{BR}-11 *$ & 1N2E3 NWSW & & \\
\hline BR-12 & 1N3E29 SENE & & \\
\hline BR-13 & 1N3E28 NWNE & $235-255$ & 245 \\
\hline BR-14 & 1N3E10 NENW & $133-153$ & 143 \\
\hline BR-15 * & 1N2E13 NWSW & & \\
\hline BR-16 & 1N3E8 NWNW & $110-130$ & 120 \\
\hline BR-17 & 1N3E4 NWNW & $65-75$ & 70 \\
\hline BR-18 A-L & 1N2E24 ENW & & \\
\hline BR-19 A-G & 1N2E24 ENW & $52-72 \quad 135-182$ & 130 \\
\hline BR-20 & 1N3E6N SWSW & $190-200250-300$ & 235 \\
\hline BR-21 & 1N3E6N SWSW & $265-296$ & 280 \\
\hline BR-22 & 1N3E6P NESW & & \\
\hline BR-23 & 1N2E13 SENE & $112-142$ & 127 \\
\hline BR-24 & 1N3E19D & $92-116 ? ? ?$ & \\
\hline BR-25 & 1N3E6P & & \\
\hline BR-26 & 1N3E6L & & \\
\hline BR-27 & 1N3E8R & $102-112130-140$ & 120 \\
\hline BR-28 & 1N3E20C & $99-124$ & 112 \\
\hline BR-29 & 1N3E17E & & \\
\hline BR-30 & 1N3E20E & $115-195260-300$ & 200 \\
\hline BR-31 & 1N3E8P & $132-140$ & 186 \\
\hline BR-32 & 1N3E20D & $115-125 \quad 170-290$ & 222 \\
\hline BR-33 & 1N3E17R & & \\
\hline BR-34 & 1N2E24H & & \\
\hline BR-35 & 1N2E24G & & \\
\hline
\end{tabular}

Oil

Canal

Canal

Canal

Canal

Canal

Canal

Tile Drain

Boys School

Canal

Canal

Canal

Domestic

Irrigation 1983

Domestic 1986

Canal

Domestic 1986

Domestic 1973

Municipal 1994

Municipal 1994

Municipal 1987

Municipal 1988

Municipal

Municipal 1966

Municipal 1954

Irrigation

Irrigation

Domestic $\quad 1988$

Irrigation 1989

Domestic

Irrigation $\quad 1972$

Irrigation 1968

Irrigation 1972

Irrigation

Irrigation

Irrigation

Irrigation 
Table 1: Brentwood Region Samples

Sample

BR-37

BR-38

BR-39

BR-40

BR-41

BR-42

BR-43

BR-44

BR-45

BR-46

BR-47

BR-48

BR-49

BR-50

BR-51

BR-52

BR-53

BR-54

BR-55

BR-56

BR-57

BR-58

BR-59

BR-60

BR-61

BR-62

BR-63

BR-64

BR-65

BR-66

BR-67

BR-68

BR-69

BR-70-1

BR-70-2

BR-70-3

BR-71
Township/Rangel

Section

1N2E24K

1N2E24L

1N2E24M

1N2E24M

1N3E19

1N3E18

1N2E26K

1N2E25E

1N3E20L

1N3E19Q

1N3E30N

IN3E30B

1N2E11

1N2E11B

1N2E14R

1N2E12B

1N2E13D

2N2E35Q

1N3E8E

1N2E12A

1N3E16F

1N3E7M

1N3E9H

1N3E8A

1N3E9R

1N3E4J

1N3E10R

1N3E22H

1N3E22Q

1N3E3D

1N3E10P

1N3E5N

1N3E3A

1N2E25K

1N2E25K

1N2E25K

1N3E32L (fbs)

120-140

65-85

173-193

92-146 182-230

20-25 89-148

74-104

70-90

120-140

60-80

65-86

200-220

65-75

225-245

95-115

187-207

280-300

$118-138$

238-258 27்-295

$100-120$

120-140

.123-143

275-295

118-138

$100-120$

240-260

$100-160$

20-80

195-215 235-255 225
Sample/Well Well Age Perforation (fbs) Type

Irrigation

Irrigation 1979

Domestic 1978

Domestic

Domestic 1987

Irrigation 1966

Industrial

Domestic 1988

Irrigation 1965

Domestic 1987

Domestic

Domestic 1981

Domestic 1985

Domestic 1986

Domestic

Domestic $\quad 1987$

Domestic 1977

Domestic 1984

Domestic

Domestic 1979

Domestic 1983

Domestic

Domestic 1990

Domestic 1984

Domestic

Domestic 1988

Domestic 1983

Domestic 1989

Domestic 1982

Domestic 1982

Domestic 1988

Domestic 1986

Domestic 1983

Domestic 1990

Domestic 1990

Domestic

Irrigation 1989 
Table 1: Brentwood Region Samples

\begin{tabular}{|c|c|c|c|c|c|}
\hline Sample & $\begin{array}{l}\text { Township/Range/ } \\
\text { Section }\end{array}$ & $\begin{array}{l}\text { Perforation Depth } \\
\text { (fbs) }\end{array}$ & $\begin{array}{l}\text { Avgerage } \\
\text { Perforation (fbs) }\end{array}$ & $\begin{array}{l}\text { Sample/Well } \\
\text { Type }\end{array}$ & Well Age \\
\hline BR-72 & 1N3E32D & $120-140$ & 130 & Domestic & 1989 \\
\hline BR-73 & 1N3E27R & $300-320$ & 310 & Domestic & 1978 \\
\hline BR-74 & 1N3E27 & & & Domestic & \\
\hline BR-75 & 1N3E28N & $145-165$ & 155 & Domestic & 1986 \\
\hline BR-76 & $1 \mathrm{~N} 3 \mathrm{ED}$ & $197-302$ & 250 & School & 1964 \\
\hline BR-77 & 1N3EP & $85-90 \quad 147-204$ & 132 & School & 1984 \\
\hline BR-78 & 1N3EE & $124-148$ & 136 & Irrigation & 1957 \\
\hline BR-79 & 1N2EK & $112-138$ & 125 & Domestic & 1987 \\
\hline BR-80 & 1N3E33H & $165-190$ & 178 & Domestic & 1983 \\
\hline BR-81 & 1N3E33F & $160-170$ & 165 & Domestic & 1989 \\
\hline BR-82 & 1N3E19J & & & & \\
\hline BR-83 & 1N3E29Q & $370-386$ & 378 & Industrial & 1950 \\
\hline BR-84 & $1 \mathrm{~N} 3 \mathrm{E} 21 \mathrm{H}$ & & & Domestic & \\
\hline BR-85 & 1N3E21R & & & Domestic & \\
\hline BR-86 & 1N3E8N & & & Domestic & \\
\hline BR-87 & 1N2E2M & & & School & \\
\hline BR-88 & 1N3E35H & $260-363$ & 314 & Municipal & \\
\hline BR-89 & 1N3E36E & $318-358$ & 338 & Municipal & \\
\hline BR-90 & $1 N 3 E 25 N$ & $258-348$ & 303 & Municipal & \\
\hline BR-91 & 1N3E25E & $235-335$ & 285 & Municipal & \\
\hline BR-92 & 1N3E25C & $265-345$ & 306 & Municipal & \\
\hline
\end{tabular}


Table 2: Field and Lab Results of Groundwater From the Brentwood Region.

\begin{tabular}{|c|c|c|c|c|c|c|c|c|c|}
\hline Sample & $\delta^{180}$ & $\delta \mathrm{D}$ & ${ }^{14} \mathrm{C}$ & Apparent Age & Model Age & ${ }^{13} \mathrm{C}$ & Lab Nitrate & Field Nitrate & Conductivity \\
\hline Termco Oil & -7.5 & & & & & 22.3 & & 0 & 3100 \\
\hline BR-1 * & & & & & & & 22.6 & & \\
\hline BR-2 * & -8.7 & & & & & & 21.6 & & \\
\hline BR-3 * & -9.4 & & 101.9 & & -1321 & & & 7.5 & 531 \\
\hline BR-4 * & -9.3 & & & & & & & 5 & 545 \\
\hline BR-5 * & -8.9 & & & & & & & & 556 \\
\hline BR-6 * & -9.3 & & & & & & & & 460 \\
\hline $\mathrm{BR}-7$ * & -8.8 & & 99.5 & & -1159 & & & 100 & 1926 \\
\hline BR-8 & & & & & & & & 0 & 1527 \\
\hline BR-9 * & -9.3 & & & & & & & 5 & 535 \\
\hline BR-10* & -9.2 & & & & & & & 15 & 708 \\
\hline BR-11 * & -9.1 & & & $\because$ & & & & 10 & 567 \\
\hline BR-12 & -8.7 & & & & & & & 100 & 2000 \\
\hline BR-13 & -7.9 & -59 & 73.2 & 2511 & 922 & -14.0 & 16.9 & 25 & \\
\hline BR-14 & -6.9 & & 51.5 & 5335 & 3161 & -13.8 & & 0 & \\
\hline BR-15 * & & & & & & & & 7.5 & \\
\hline BR-16 & -7.3 & & & & & & & 0 & \\
\hline BR-17 & -9.1 & & 102.7 & -214 & -1377 & -15.3 & & 50 & \\
\hline R-18 A-L & -7.0 & -51 & 72.9 & 2541 & 947 & -12.5 & & 0 & 1025 \\
\hline R-19 A-G & -7.8 & -59 & 100.8 & -64 & -1248 & -15.2 & & 26 & 1655 \\
\hline BR-20 & -7.2 & -52 & & & & & & 15 & 1227 \\
\hline BR-21 & -7.1 & -52 & 57.1 & & 2516 & & & 5 & 1215 \\
\hline BR-22 & -7.1 & & & & & & & 5 & 1032 \\
\hline BR-23 & -8.3 & -63 & & & & & & 75 & 1646 \\
\hline BR-24 & -8.7 & -68 & 94.0 & 497 & -766 & -15.4 & & 50 & 1563 \\
\hline
\end{tabular}

* Canal surface water sample 
Table 2: Field and Lab Results of Groundwater From the Brentwood Region.

\begin{tabular}{|c|c|c|c|c|c|c|c|c|c|c|c|c|}
\hline Sample & $\mathrm{Lab} \mathrm{pH}$ & DO & $\mathrm{T}^{\circ} \mathrm{C}$ & Field Alkalinity Lab Alkalinity & $\mathrm{Ca}$ & $\mathrm{Na}$ & $\mathrm{Mg}$ & $\mathrm{Cl}$ & $\mathrm{SO}_{4}$ & $\mathrm{~K}$ & B & $\mathrm{Si}$ \\
\hline \multicolumn{13}{|c|}{ Termco Oil } \\
\hline $\mathrm{BR}-1$ * & 5.58 & & & & 0 & 29 & 0 & 48 & 6 & 4.9 & 0.3 & 0.0 \\
\hline $\mathrm{BR}-2 *$ & 5.57 & & & & 4 & 29 & 0 & 48 & 72 & 4.2 & 0.3 & 0.0 \\
\hline $\mathrm{BR}-3$ * & & & & & & & & & & & & \\
\hline $\mathrm{BR}-4 *$ & & & & & & & & & & & & \\
\hline $\mathrm{BR}-5$ * & & & & & & & & & & & & \\
\hline $\mathrm{BR}-6 *$ & & & & & & & & & & & & \\
\hline $\mathrm{BR}-7$ * & & & & & & & & & & & & \\
\hline $\mathrm{BR}-8$ & & & & & & & & & & & & \\
\hline BR-9 * & & & & & & & & & & & & \\
\hline BR-10* & & & & & & & & & & & & \\
\hline BR-11 * & & & & $\because$ & & & & & & & & \\
\hline BR-12 & & & 17.5 & 400 & & & & & & & & \\
\hline BR-13 & 7.99 & & 18.5 & 300 & 80 & 124 & 49 & 190 & & 1.2 & 1.9 & 22.1 \\
\hline BR-14 & & & 21.5 & 300 & & & & & & & & \\
\hline $\mathrm{BR}-15$ * & & & 21.0 & & & & & & & & & \\
\hline BR-16 & & & 21.0 & 300 & & & & & & & & \\
\hline BR-17 & & & 18.0 & 300 & & & & & & & & \\
\hline
\end{tabular}

BR-19 A-G

BR-20

BR-21

BR-22

BR-23

BR-24

* Canal surface water sample 
Table 2: Field and Lab Results of Groundwater From the Brentwood Region.

Sample $\quad \delta^{18} \mathrm{O} \quad \delta \mathrm{D} \quad{ }^{14} \mathrm{C} \quad$ Apparent Age Model Age $\quad{ }^{13} \mathrm{C} \quad$ Lab Nitrate Field Nitrate Conductivity Field pH

\begin{tabular}{|c|c|c|c|c|c|c|c|c|c|c|}
\hline BR-25 & -7.7 & & & & & & & 25 & 1172 & \\
\hline BR-26 & -7.5 & & & & & & & 15 & 1022 & \\
\hline BR-27 & -7.4 & -55 & 52.7 & 5153 & 3022 & -13.1 & 8.5 & 10 & 1017 & 7.4 \\
\hline BR-28 & -9.2 & -71 & 83.3 & 1466 & 55 & -14.3 & 29.2 & 50 & 1326 & 7.7 \\
\hline BR-29 & -7.9 & -60 & & & & & 29.2 & 60 & 1345 & 7.9 \\
\hline BR-30 & -8.7 & -67 & & & & & 33.4 & 50 & 1291 & 7.6 \\
\hline BR-31 & -8.7 & & & & & & & 50 & 1543 & 7.8 \\
\hline BR-32 & -8.4 & & & & & & & 50 & 1354 & 7.6 \\
\hline BR-33 & -8.8 & & 100.2 & -19 & -1209 & -15.6 & 59.0 & 80 & 1712 & 7.6 \\
\hline BR-34 & -8.4 & & & & & & & 50 & 1499 & 7.7 \\
\hline BR-35 & -7.9 & & & & & & & 40 & 1377 & 7.6 \\
\hline BR-36 & -9.1 & & & & & & & 100 & 1630 & 7.6 \\
\hline BR-37 & -8.3 & & & & & & & 50 & 1537 & 7.6 \\
\hline BR-38 & -7.0 & & 68.8 & 3009 & 1328 & -12.5 & & 0 & 1127 & 7.6 \\
\hline BR-39 & -7.8 & -59 & 94.1 & 491 & -771 & -14.6 & & 25 & 1377 & 7.3 \\
\hline BR-40 & -7.1 & -51 & & & & & 15.7 & 25 & 1167 & 7.4 \\
\hline BR-41 & -8.7 & & 91.5 & 718 & -577 & -14.9 & & 50 & 1394 & 7.4 \\
\hline BR-42 & -8.3 & -65 & & & & & & 50 & 1433 & 7.4 \\
\hline BR-43 & -6.6 & -52 & 35.7 & 8283 & 5306 & -16.3 & & 0 & 252 & 6.6 \\
\hline BR-44 & -7.9 & & & & & & 37.7 & 50 & 1277 & 7.2 \\
\hline BR-45 & -8.8 & & & & & & 30.5 & 50 & 1337 & 7.6 \\
\hline BR-46 & -8.9 & -70 & & & & & 95.0 & 100 & 1960 & \\
\hline BR-47 & -8.5 & -66 & & & & & & 35 & 1647 & 8.0 \\
\hline BR-48 & -8.8 & -68 & & & & & & 50 & 1470 & 7.9 \\
\hline BR-49 & -7.7 & -61 & 77.1 & 2092 & 577 & -9.7 & 49.8 & 100 & 2630 & 7.4 \\
\hline BR-50 & -8.6 & -66 & & & & & & 50 & 2190 & 7.2 \\
\hline BR-51 & -8.7 & & & & & & & 75 & 1805 & 7.3 \\
\hline
\end{tabular}

* Canal surface water sample 
Table 2: Field and Lab Results of Groundwater From the Brentwood Region.

\begin{tabular}{|c|c|c|c|c|c|c|c|c|c|c|c|c|c|}
\hline Sample & Lab pH & DO & $\mathrm{T}^{\circ} \mathrm{C}$ & Field Alkalinity Lab & Alkalinity & $\mathrm{Ca}$ & $\mathrm{Na}$ & $\mathrm{Mg}$ & $\mathrm{Cl}$ & $\mathrm{SO}_{4}$ & $\mathrm{~K}$ & B & $\mathrm{Si}$ \\
\hline \multicolumn{14}{|l|}{ BR-25 } \\
\hline \multicolumn{14}{|l|}{ BR-26 } \\
\hline BR-27 & 7.86 & & & 300 & 154.3 & 62 & 104 & 39 & 100 & 125 & 0.9 & 1.8 & 26.7 \\
\hline BR-28 & 8.37 & & 21.0 & 300 & 161.0 & 96 & 127 & 43 & 195 & 129 & 1.2 & 1.7 & 23.3 \\
\hline BR-29 & 7.91 & & & 250 & 127.5 & 106 & 110 & 48 & 164 & 240 & 3.0 & 1.4 & 28.1 \\
\hline BR-30 & 7.78 & & & 300 & 158.6 & 98 & 112 & 45 & 171 & 148 & 2.4 & 1.9 & 28.5 \\
\hline BR-31 & & & & 300 & & & & & & & $\cdot$ & & \\
\hline BR-32 & & 7.0 & & 300 & & & & & & & & & \\
\hline BR-33 & 7.64 & 6.0 & & 400 & 196.4 & 112 & 172 & 65 & 238 & 195 & 0.6 & 1.8 & 28.7 \\
\hline BR-34 & & 12.0 & 20.0 & 310 & & & & & & & & & \\
\hline BR-35 & & 12.0 & & 350 & & & & & & & & & \\
\hline BR-36 & & 1.0 & & 300 & & & & & & & & & \\
\hline $\mathrm{BR}-37$ & & 7.0 & & 300 & & & & & & & & & \\
\hline BR-38 & & & & 275 & & & & & & & & & \\
\hline BR-39 & & & & 300 & & & & & & & & & \\
\hline BR-40 & 7.62 & & & 350 & 160.4 & 78 & 118 & 45 & 124 & 170 & 4.9 & 1.7 & 77.3 \\
\hline \multicolumn{14}{|l|}{ BR-41 } \\
\hline $\mathrm{BR}-42$ & & 3.0 & & & & & & & & & & & \\
\hline BR-43 & & 3.0 & & & & & & & & & & & \\
\hline BR-44 & 7.54 & 6.0 & & & 153.1 & 96 & 107 & 50 & 152 & 169 & 3.4 & 1.5 & 45.9 \\
\hline$B R-45$ & 7.79 & 5.0 & & & 185.4 & 86 & 120 & 52 & 171 & 117 & 1.8 & 1.7 & 26.9 \\
\hline $\mathrm{BR}-46$ & 7.71 & 4.0 & & & 236.7 & 166 & 149 & 81 & 267 & 207 & 2.0 & 1.3 & 29.8 \\
\hline \multicolumn{14}{|l|}{ BR-47 } \\
\hline BR-48 & & 8.0 & & & & & & & & & & & \\
\hline$B R-49$ & 7.69 & 2.0 & 21.0 & & 201.3 & 170 & 282 & 106 & 300 & 698 & 5.4 & 2.6 & 47.9 \\
\hline BR-50 & & 4.0 & 20.0 & & & & & & & & & & \\
\hline BR-51 & & 4.5 & 25.0 & & & & & & & & & & \\
\hline
\end{tabular}


Table 2: Field and Lab Results of Groundwater From the Brentwood Region.

\begin{tabular}{|c|c|c|c|c|c|c|c|c|c|c|}
\hline Sample & $\delta^{180}$ & $\delta \mathrm{D}$ & ${ }^{14} \mathrm{C}$ & Apparent Age & Model Age & ${ }^{13} \mathrm{C}$ & Lab Nitrate & Field Nitrate & Conductivity & Field pF \\
\hline BR-52 & -7.8 & -62 & & & & & & 50 & 1730 & 7.7 \\
\hline BR-53 & -8.1 & & & & & & & 50 & 2040 & 7.3 \\
\hline BR-54 & -7.8 & & 66.2 & 3320 & 1580 & -13.8 & 15.6 & 25 & 1810 & 7.6 \\
\hline BR-55 & -6.9 & -51 & 53.0 & & 2983 & & 4.4 & 5 & 950 & 7.4 \\
\hline BR-56 & -8.0 & & & & & & & 5 & 1660 & 7.4 \\
\hline BR-57 & -7.0 & -50 & & & & & 2.5 & 5 & 944 & 7.4 \\
\hline BR-58 & -8.2 & & & & & & & 50 & 1273 & 7.5 \\
\hline BR-59 & -7.0 & & & & & & 3.4 & 0 & 884 & 7.5 \\
\hline BR-60 & -7.3 & -53 & & & & & & 5 & 1128 & 7.6 \\
\hline BR-61 & -8.0 & -60 & 84.6 & 1342 & -50 & -13.4 & 43.9 & 90 & 1650 & 7.7 \\
\hline BR-62 & -7.0 & -50 & 49.9 & 5579 & 3346 & -11.5 & 2.2 & 0.5 & 843 & 7.7 \\
\hline BR-63 & -6.7 & -49 & 37.4 & $\therefore 7911$ & 5047 & -15.0 & & 0.5 & 1170 & 7.5 \\
\hline BR-64 & -7.4 & -56 & 62.9 & 3721 & 1901 & -13.0 & & 0.5 & 1248 & 7.6 \\
\hline BR-65 & -6.6 & -53 & 66.3 & 3306 & 1569 & -12.6 & & 0.5 & 1217 & 7.6 \\
\hline BR-66 & -7.0 & & 48.7 & 5786 & 3503 & -13.3 & & 0 & 848 & 8.0 \\
\hline BR-67 & -7.4 & -55 & 60.1 & 4093 & 2196 & -13.3 & & 0.5 & 1763 & 7.7 \\
\hline BR-68 & -7.0 & & & & & & & 5 & 969 & 7.6 \\
\hline BR-69 & -6.8 & -49 & 62.3 & 3800 & 1964 & -12.8 & & 0 & 866 & 7.9 \\
\hline BR-70-1 & -6.5 & -46 & 82.6 & 1536 & 113 & -11.2 & 0.0 & 0 & 1445 & 7.4 \\
\hline BR-70-2 & -7.0 & -51 & & & & & & 5 & 1351 & 7.5 \\
\hline BR-70-3 & & & & & & & & 5 & 1377 & 7.6 \\
\hline BR-71 & -7.9 & & & & & & 37.7 & 50 & 1381 & 7.3 \\
\hline BR-72 & -7.5 & -55 & & & & & 12.7 & 7.5 & 1386 & 7.1 \\
\hline BR-73 & -7.1 & & 29.0 & 9949 & 6418 & & 0.0 & 0 & 886 & 7.5 \\
\hline BR-74 & -9.1 & & & & & & 35.8 & 50 & 1535 & 7.1 \\
\hline BR-75 & -8.5 & -68 & 94.6 & 445 & -810 & -14.8 & 59.0 & 50 & 1723 & 7.3 \\
\hline BR-76 & -7.8 & & 86.4 & 1172 & -192 & -14.0 & & 50 & 1498 & 7.5 \\
\hline
\end{tabular}

\footnotetext{
* Canal surface water sample
} 
Table 2: Field and Lab Results of Groundwater From the Brentwood Region.

\begin{tabular}{|c|c|c|c|c|c|c|c|c|c|c|c|c|c|}
\hline Sample & $\mathrm{Lab} \mathrm{pH}$ & DO & $\mathrm{T}^{\circ} \mathrm{C}$ & Field Alkalinity Lab & Alkalinity & $\mathrm{Ca}$ & $\mathrm{Na}$ & $\mathrm{Mg}$ & $\mathrm{Cl}$ & $\mathrm{SO}_{4}$ & $\mathrm{~K}$ & B & $\mathrm{Si}$ \\
\hline BR-52 & & 4.5 & 21.5 & & & & & & & & & & \\
\hline BR-53 & & 3.5 & 19.5 & & & & & & & & & & \\
\hline BR-54 & 7.79 & 4.0 & 25.0 & & 128.1 & 106 & 218 & 52 & 229 & 414 & 3.4 & 1.2 & 34.8 \\
\hline BR-55 & 7.84 & 1.0 & 22.5 & & 153.1 & 64 & 93 & 37 & 86 & 143 & 0.8 & 1.5 & 26.0 \\
\hline BR-56 & & 5.0 & & & & & & & & & & & \\
\hline BR-57 & 7.81 & 2.0 & 22.0 & & 154.9 & 58 & 97 & 35 & 90 & 112 & 1.0 & 2.1 & 29.6 \\
\hline BR-58 & & 6.0 & 25.0 & & & & & & & & & & \\
\hline BR-59 & 7.78 & 4.0 & 26.0 & & 146.4 & 56 & 93 & 33 & 76 & 120 & 1.3 & 1.6 & 25.4 \\
\hline BR-60 & & & 23.5 & & & & & & & & & & \\
\hline BR-61 & 7.81 & & 23.0 & & 148.2 & 84 & 180 & 67 & 257 & 227 & 2.0 & 1.8 & 28.6 \\
\hline BR-62 & 7.86 & & 26.0 & & 147.0 & 62 & 89 & 23 & 69 & 105 & 1.2 & 1.3 & 27.3 \\
\hline BR-63 & & 1.0 & 21.5 & & & & & & & & & & \\
\hline BR-64 & & & 27.0 & & & & & & & & & & \\
\hline BR- 65 & & & 22.5 & & & & & & & & & & \\
\hline BR-66 & & 1.5 & 24.0 & & & & & & & & & & \\
\hline BR-67 & & 3.5 & 24.0 & & & & & & & & & & \\
\hline BR-68 & & 0.5 & 22.5 & & & & & & & & & & \\
\hline BR-69 & & 1.0 & 23.5 & & & & & & & & & & \\
\hline BR-70-1 & 7.69 & 5.0 & 25.0 & & 205.6 & 88 & 167 & 45 & 198 & 145 & 4.6 & 2.8 & 77.0 \\
\hline BR-70-2 & & 9.0 & 24.0 & & & & & & & & & & \\
\hline BR-70-3 & & 6.0 & 22.5 & & & & & & & & & & \\
\hline BR-71 & 7.74 & 5.0 & 22.0 & & 184.8 & 84 & 147 & 45 & 181 & 116 & 1.0 & 1.8 & 21.1 \\
\hline BR-72 & 7.70 & 6.0 & 23.5 & & 169.0 & 76 & 158 & 45 & 198 & 150 & 1.2 & 3.1 & 22.4 \\
\hline BR-73 & 7.96 & 0.5 & 22.5 & & 147.6 & 34 & 118 & 27 & 83 & 104 & 0.6 & 1.6 & 28.4 \\
\hline BR-74 & 8.26 & 0.5 & 22.0 & & 225.1 & 52 & 181 & 66 & 186 & 151 & 0.0 & 2.0 & 19.7 \\
\hline BR-75 & 7.73 & 8.0 & 23.5 & & 242.2 & 110 & 161 & 72 & 221 & 154 & 1.8 & 2.1 & 23.8 \\
\hline BR-76 & & 5.0 & 20.1 & 225 & & & & & & & & & \\
\hline
\end{tabular}

* Canal surface water sample 
Table 2: Field and Lab Results of Groundwater From the Brentwood Region.

\begin{tabular}{|c|c|c|c|c|c|c|c|c|c|c|}
\hline Sample & $\delta^{180}$ & $\delta \mathrm{D}$ & ${ }^{14} \mathrm{C}$ & Apparent Age & Model Age & ${ }^{13} \mathrm{C}$ & Lab Nitrate & Field Nitrate & Conductivity & Field $\mathrm{pH}$ \\
\hline BR-77 & -8.5 & & & & & & 52.0 & 60 & 1890 & 7.4 \\
\hline BR-78 & -8.0 & & & & & & & 50 & 1650 & 7.3 \\
\hline BR-79 & -7.7 & & & & & & 12.4 & 2.5 & 1429 & 7.5 \\
\hline BR-80 & -6.9 & & & & & & & 1.5 & 1211 & 7.5 \\
\hline BR-81 & -8.2 & & & & & & 34.9 & 50 & 1516 & 7.5 \\
\hline BR-82 & -8.4 & & & & & & & & 1265 & \\
\hline BR-83 & -7.6 & & 78.0 & & 494 & & 14.9 & & 1375 & \\
\hline BR-84 & -8.2 & & & & & & & 25 & 1288 & 7.7 \\
\hline BR-85 & -8.3 & & & & & & & 150 & 1499 & 7.7 \\
\hline BR-86 & -8.4 & & & & & & & 100 & 1430 & 7.5 \\
\hline BR-87 & -7.7 & & & & & & & 50 & 1250 & 7.8 \\
\hline BR-88 & -7.0 & & 19.8 & 13009 & 8252 & -13.9 & & 0.9 & 1211 & 8.2 \\
\hline BR-89 & -6.9 & & & & & & & 0.9 & 1256 & 8.1 \\
\hline BR-90 & -7.0 & & & & & & & 0.9 & 1174 & 8.1 \\
\hline BR-91 & -7.0 & & & & & & & 0.9 & 1210 & 8.0 \\
\hline BR-92 & -7.1 & & & & & & & 0.9 & 1269 & 8.2 \\
\hline
\end{tabular}

* Canal surface water sample 
Table 2: Field and Lab Results of Groundwater From the Brentwood Region.

\begin{tabular}{|c|c|c|c|c|c|c|c|c|c|c|c|c|c|}
\hline Sample & $\mathrm{Lab} \mathrm{pH}$ & DO & $\mathrm{T}^{\circ} \mathrm{C}$ & Field Alkalinity Lab & Alkalinity & $\mathrm{Ca}$ & $\mathrm{Na}$ & $\mathrm{Mg}$ & $\mathrm{Cl}$ & $\mathrm{SO}_{4}$ & $\mathrm{~K}$ & B & $\mathrm{Si}$ \\
\hline BR-77 & 7.55 & & 21.1 & 250 & 189.1 & 138 & 141 & 85 & 295 & 201 & 1.2 & 0.8 & 25.2 \\
\hline BR-78 & & & 22.2 & 225 & & & & & & & & & \\
\hline BR-79 & 7.60 & & 23.9 & 200 & 137.3 & 114 & 105 & 50 & 226 & 172 & 1.8 & 0.9 & 27.3 \\
\hline BR-80 & & & 23.3 & & & & & & & & & & \\
\hline BR-81 & 7.66 & & 22.8 & 200 & 195.8 & 100 & 156 & 43 & 207 & 138 & 2.0 & 2.3 & 22.3 \\
\hline BR-82 & & & 28.4 & 275 & & & & & & & & & \\
\hline BR-83 & 7.69 & 2.0 & 23.8 & & 181.8 & 106 & 118 & 49 & 190 & 145 & 1.6 & 2.1 & 22.4 \\
\hline BR-84 & & 3.0 & 20.2 & 250 & & & & & & & & & \\
\hline BR-85 & & 4.0 & & 21.1 & & & & & & & & & \\
\hline BR-86 & & 0.5 & 21.1 & 300 & & & & & & & & & \\
\hline BR-87 & & 7.0 & 22.5 & 225 & & & & & & & & & \\
\hline BR-88 & & 0.5 & 21.1 & $\because$ & & & & & & & & & \\
\hline BR-89 & & 1.0 & 16.7 & 225 & & & & & & & & & \\
\hline BR-90 & & 1.0 & 18.9 & & & & & & & & & & \\
\hline BR-91 & & 3.5 & 18.9 & & & & & & & & & & \\
\hline BR-92 & & & 19.4 & & & & & & & & & & \\
\hline
\end{tabular}

\footnotetext{
* Canal surface water sample
} 


\section{Appendix 1}

Stable Isotopes_- A water molecule is made from two hydrogen atoms and one oxygen atom. We use natural isotopes of these atoms to trace water in the hydrologic cycle. Isotopes is a name for different types of atoms of the same element characterized by different number of neutrons in its nucleus. The element of oxygen is made of 3 different kinds of atoms or isotopes. The most abundant (99.8\%) is oxygen-16 (160). The secondmost abundant $(0.2 \%)$ is oxygen- $18(180)$. The least abundant $(0.04 \%)$ is oxygen -17 , but because it is so rare, we can ignore it for hydrologic studies. Likewise, the element hydrogen also has three different kinds of isotopes. Hydrogen $(\mathrm{H})$ is the most abundant (99.9\%). Deuterium (D) is the second-most abundant $(0.01 \%)$. Tritium $\left({ }^{3} \mathrm{H}\right)$ is the least abundant and is radioactive. Tritium has hydrologic applications but is not part of this proposal.

We are concerned with the relative abundance of 180 and deuterium in different phases of the hydrologic cycle, i.e. liquid water, water vapor, and ice. All water in the hydrologic cycle originates from the ocean. For the most part, the liquid water in the ocean has a uniform $18 \mathrm{O}$ and deuterium abundance throughout the world. Water in clouds (water vapor), rain, and ice have $18 \mathrm{O}$ and deuterium abundances that differ from ocean water. This difference arises because natural chemical laws force more 180 and deuterium to stay in one phase over another. In fact, the more solid the water phase the more ${ }^{18} \mathrm{O}$ and deuterium is incorporated in the water molecules, i.e. ice has more $18 \mathrm{O}$ and deuterium than water, and water has more $18 \mathrm{O}$ and deuterium than clouds. The absolute amount of $18 \mathrm{O}$ and deuterium in any one phase depends on temperature only. Therefore, rain and snow near the polar regions of the earth have less 180 and deuterium than rain water in the tropical or equatorial regions. This simple law allows us to trace the origin of a water sample by measuring its absolute $18 \mathrm{O}$ and deuterium abundance.

All $18 \mathrm{O}$ and deuterium measurements are normalized to ocean water abundances. This allows us to compare the ${ }^{18} \mathrm{O}$ and deuterium abundance in a hydrologic sample to its 
parent water. The normalization of the $18 \mathrm{O}$ and deuterium is accomplished by comparing the $18 \mathrm{O} / 16 \mathrm{O}$ ratio and the $\mathrm{D} / \mathrm{H}$ ratio to the same ratios of ocean water such that,

$$
\delta=\left(\frac{{ }^{18} O^{16} O_{n w}}{{ }^{18} O^{16} O_{S M O W}}-1\right) 1000 \quad \text { and } \quad \delta=\left(\frac{D / H_{n w}}{D / H_{S M O W}}-1\right) 1000
$$

where ${ }^{18} \mathrm{O} / 16 \mathrm{O}_{n w}$ and $\mathrm{D} / \mathrm{H}_{n w}$ are the isotopic ratios of a rain water, and ${ }^{18} \mathrm{O} / 16 \mathrm{O}_{S M O W}$ and $D / H_{S M O W}$ are the isotopic ratios of an ocean water standard or Standard Mean Ocean Water. The $\delta$ symbol is pronounced "del" and normalized data are referred to as $\delta^{180}$ and $\delta \mathrm{D}$. We also refer to the $\delta^{18} \mathrm{O}$ and $\delta \mathrm{D}$ values as a "per mil" (\%o, or parts per thousand). Notice that if you normalize the SMOW standard against itself, then its $\delta^{18} O$ and $\delta \mathrm{D}$ values are both $0 \%$. This is the value of ocean water. Since $18 \mathrm{O}$ and deuterium tend to stay in the more solid phase, almost all rain produced on land from clouds have $\delta 18 \mathrm{O}$ and $\delta \mathrm{D}$ values less than zero. For instance, rain waters on the western side of the Central Valley of California have, on average throughout the winter, $\delta^{18} \mathrm{O}$ values approximately between -7.0 and $-8.0 \%$, and $\delta \mathrm{D}$ values approximately between -46 and $-54 \%$, as shown by our previous work (Davisson and Criss, 1993). These rain water "signatures" retain their values as they recharge into the groundwater beneath the surface.

Surface waters that evaporate lose water by releasing water vapor to the atmosphere. We can exploit the isotopic effects of $18 \mathrm{O}$ and deuterium in evaporating waters. Because more ${ }^{18} \mathrm{O}$ and deuterium stay in the liquid phase than the vapor phase, evaporating waters, such as lakes, reservoirs, irrigation water, etc., will over time increase their $18 \mathrm{O}$ and deuterium abundances, and hence increase their $\delta^{18} \mathrm{O}$ and $\delta \mathrm{D}$ values. This "enrichment" of the $\delta^{18} \mathrm{O}$ and $\delta \mathrm{D}$ values allows us to distinguish water that has a rain water isotopic value from a water with an evaporated isotopic value. This allows us to distinguish groundwaters that are recharge principally from winter rain storms from those 
recharged from evaporated water sources, such as agricultural irrigation water, reservoir water, or even Delta water.

In addition, water that has been imported from Sierra Nevada sources, such as the San Joaquin River, will have lower $\delta^{18} \mathrm{O}$ and $\delta \mathrm{D}$ values than the locally derived groundwater (i.e. rain water or evaporated surface water). Snow and rain that falls in the Sierra Nevada has less ${ }^{18} \mathrm{O}$ and deuterium than rain water in the Valley because of the orographic effects from increased elevation (lower temperatures) and distance from the ocean.

Carbon-14_-The natural element of carbon is made up of three different kinds of atoms. The most abundant (99\%) is carbon-12 (12C). The second most abundant (1\%) is carbon$13\left({ }^{13} \mathrm{C}\right)$. A very small amount of carbon atoms are carbon- 14 (written as " $14 \mathrm{C}$ " or "radiocarbon"), which unlike the other two is not stable and is constantly decaying to the element nitrogen. At the same time, though, new ${ }^{14} \mathrm{C}$ atoms are being made in the upper atmosphere by high-energy particles colliding with other atoms. The rate of ${ }^{14} \mathrm{C}$ production in the upper atmosphere is matched by the rate at which ${ }^{14} \mathrm{C}$ converts to nitrogen.

Once the ${ }^{14} \mathrm{C}$ atom is made, it typically is incorporated into a $\mathrm{CO}_{2}$ molecule. That $\mathrm{CO}_{2}$ molecule will be circulated down near the surface of the earth where plants can utilize it in their biological processes. Plants also expel excess $\mathrm{CO}_{2}$ through their roots. This excess $\mathrm{CO}_{2}$ respired through their roots will also have the same tiny amount of ${ }^{14} \mathrm{C}$ atoms as the atmosphere. When it rains, water will percolate through the soil, and dissolve the $\mathrm{CO}_{2}$ the plant has respired from its roots. The dissolved $\mathrm{CO}_{2}$ becomes $\mathrm{HCO}_{3}$ in the water and will be carried down into a groundwater aquifer. Once the $\mathrm{HCO}_{3}$ is in the aquifer, it can't communicate with the atmosphere above and so the ${ }^{14} \mathrm{C}$ atoms in the $\mathrm{HCO}_{3}$ molecules are stuck in the aquifer. At this point, all the ${ }^{14} \mathrm{C}$ atoms in the $\mathrm{HCO}_{3}$ molecules of the groundwater begin to decay to nitrogen, but can't be replenished 
by new ${ }^{14} \mathrm{C}$ atoms. Therefore, the total ${ }^{14} \mathrm{C}$ content of the groundwater decreases with time. The rate at which ${ }^{14} \mathrm{C}$ decays has been experimentally determine by previous scientific researchers. The best way to understand the rate is by using the term half-life. This term is defined as the time it takes for half of the ${ }^{14} \mathrm{C}$ atoms to convert to nitrogen. That half-life is 5730 years. For example, if we had $100{ }^{14} \mathrm{C}$ atoms and we isolated them and let them decay, we could recount them 5730 years later and find that only 50 atoms are left. We can use this same principle to determine the age of the groundwater.

The ${ }^{14} \mathrm{C}$ atom has an unstable nucleus and decays by emission of beta particles. This converts the ${ }^{14} \mathrm{C}$ atom to a stable nitrogen atom. The rate at which the ${ }^{14} \mathrm{C}$ decays is always the same. Therefore, the ratio of ${ }^{14} \mathrm{C}$ atoms in a material measured at any given time to the initial amount in a sample is proportional to time such that:

$$
\frac{{ }^{14} C}{{ }^{14} C_{i}}=e^{-\lambda t}
$$

where ${ }^{14} \mathrm{C}$ is the amount of ${ }^{14} \mathrm{C}$ in a material at any given time, ${ }^{14} C_{i}$ is the initial amount, $t$ is time, and $\lambda$ is the proportionality constant. This ${ }^{14} C^{14} C_{i}$ ratio is known as the fraction of modern carbon. In the natural environment the ${ }^{14} C_{i}$ is constant over time. Therefore, the fraction of modern carbon will always be $\leq 1.0$. When thermonuclear above-ground testing began in the early 1950 's, an unnatural amount of ${ }^{14} \mathrm{C}$ was injected into the atmosphere. If some material has incorporated this unnaturally high ${ }^{14} \mathrm{C}$ level, then its fraction of modern carbon is $>1.0$. For natural samples, we always consider the ${ }^{14} C_{i}$ to be equal to the pre-nuclear testing atmospheric levels.

The traditional methods of measuring the amount of ${ }^{14} \mathrm{C}$ in a material is by beta counting, or counting up the number of beta particles emitted from the sample. As the ${ }^{14} \mathrm{C}$ atoms decay, the number of ${ }^{14} \mathrm{C}$ atoms can be calculated from the number of beta 
counts. Therefore, the ratio in the above equation can be represented by a ${ }^{14} \mathrm{C}$ activity (beta activity) or $A / A_{i}$

New methods involving the use of the Accelerator Mass Spectrometer at Lawrence Livermore Lab, provide a means to separate ${ }^{14} \mathrm{C}$ atoms from the more abundant ${ }^{12} \mathrm{C}$ atoms by actually counting the ${ }^{14} \mathrm{C}$ atoms in a sample. This gives us a relative amount of ${ }^{14} \mathrm{C}$ atoms to total carbon in a sample. We can then compare that relative amount of ${ }^{14} \mathrm{C}$ to the pre-nuclear test levels and derive a fraction of modern carbon. To calculate an age we just solve for $t$ in the above equation. The advantages to this new method is that only a small water sample is needed (one-hundredth the size of the traditional techniques) and the analyses are ten-times faster. 


\section{Appendix 2}

BR-3

BR-4

BR-5

BR-6

BR-7

BR-8

BR-9

BR-10

BR-11

BR-12

BR-13

BR-14

BR-15

BR-16

BR-17 .

BR-18 A-L

BR-19 A-G

BR-20

BR-21

BR-22

BR-23

BR-24

BR-25

BR-26

BR-27
Main Canal at Pumping Station \#1, at West end of Indian Slough

Main Canal at Pumping Station \#7, last pumping station on the Main Canal

Sample of tail water at Pumping Station \#3 on the Main Canal

Water lifted at Pumping Station \#3 on the Main

canal before the tail water is added

Tile drain water pumped to the surface

Boys School

3 North Lateral off of the Main Canal

300 feet West of pumping station of 4 North

Lateral

End of 7 North Lateral

Nunn Farms, Farm workers well, $1 \mathrm{mi}$. East of Sellers Avenue, $\mathbf{0 . 3}$ mi. South of Hwy 4 on dirt road, 100 yards West of road

Union Cemetery, (deepest and newest of three wells) on East side of maintenance shed $\sim 200$ feet south of Highway 4

110 feet South of Eagle Lane $0.3 \mathrm{mi}$ East of Byron Hwy

Marsh Creek at crossing with Dainty Road

East Contra Cost Historical Society, 200 feet East of Sellers Avenue, 100 yards South of Sunset

Road

Southeast Comer of Delta Road and Eden Plains

Road. Well is approx. 30 feet from the Southwest comer of the house.

City of Brentwood Well \#10,150 yards West of intersection of Continente and Griffith

City of Brentwood Well \#10A approximately 50

feet Northwest of BR-18

City of Brentwood Well \#6 50 feet South of

Homecomming Avenue and 100 yards East of

Hwy. 4

City of Brentwood Well \#7 North side of Marsh

Creek $0.15 \mathrm{mi}$. East of BR-20

City of Brentwood Well \#8 North side of Marsh

Creek 0.15 mi. East of BR-21

City of Brentwood Well \#3 $0.15 \mathrm{mi}$. North of Dainty Road at the North End (dead end) of Walnut Avenue under water tower

City of Brentwood Well \#2 Southwest comer of

Hwy. 4 and Balfour Road.

City of Brentwood Well \#9 30 yards North of

Sunset Avenue , $0.27 \mathrm{mi}$. East of Tresch Avenue at

Southwest corner of baseball park

Wastewater Treatment Plant well at Northwest comer of Northern-most shed (maintenance shed) $0.5 \mathrm{mi}$. North on Eden Plains Road to Arabian, $0.2 \mathrm{mi}$. West, approx. 30yards Southeast of

Spanish-style house 
DNA Plant Technologies $0.5 \mathrm{mi}$. East of Sellers, $0.25 \mathrm{mi}$. South of Balfour at Southeast comer of greenhouse

BR-29 O.1mi North of Chestnut Avenue, O.1mi East of Sellers Avenue, 20 yards East of Dejesus Well Drilling office

BR-30 $0.25 \mathrm{mi}$. South of Balfour Road, $0.12 \mathrm{mi}$. East of Sellers Avenue

BR-31 ECCID well \#21, $0.25 \mathrm{mi}$ East of Hwy.4, 10 feet North of Balfour Road

BR-32 ECCID well \#5, 40 feet South of Balfour Road, 200 feet East of Sellers Avenue

BR-33 ECCD well \#6 $0.9 \mathrm{mi}$. East of Sellers Avenue, 20 feet North of Balfour Road

BR-34 ECCD well \#1, $0.1 \mathrm{mi}$. West of Walnut Avenue, 200 feet Northwest of Pump Station \#6, 100 feet North of the Main Canal

BR-35 ECCID well \#3, $0.35 \mathrm{mi}$. West of Walnut Avenue, 50 feet North of Main Canal, 100 feet Northwest of where lateral goes off to south of the Main Canal ECCID well \#2, 1 mile East of Sellers Avenue, 75 feet South of Main Canal

BR-37 ECCID well \#9, $0.25 \mathrm{mi}$. West of Walnut Avenue, 30 feet North of Eureka Road

BR-38

BR-39 251 Eureka Avenue, $0.7 \mathrm{mi}$. West of Walnut Avenue, 200 feet North of Eureka Road

BR-40 New house Northeast of Brentwood Gardens, 175 yards Northeast of BR-39, 200 yards North of Eureka Road

BR-41 $0.2 \mathrm{mi}$. South of Balfour Road, $0.1 \mathrm{mi}$. West of Sellers Avenue, , 30 feet West of Northwest corner of house

BR-42 Yamanaka Well, $0.45 \mathrm{mi}$. West of Sellers Avenue, 50 feet North of Chestnut Avenue, on North side of storage shed.

BR-43 PG\&E Compression and Transmission Station, $1.5 \mathrm{mi}$. West of Walnut Avenue, 300 yards Southwest of Concord Avenue at Southwest comer of station

BR-44 2163 Concord Avenue, $1.1 \mathrm{mi}$. West of Walnut Avenue, $0.2 \mathrm{mi}$ North of Concord Avenue, 20 feet North of West comer of house

BR-45 ECCD well \#11, $0.45 \mathrm{mi}$. East of Sellers Avenue along Main Canal, 30 feet South of Main Canal

BR-46 House at east end of Eureka Road down private driveway, $0.7 \mathrm{mi}$. East of Walnut, 15 feet South of Driveway

BR-47 Yellow house with new well, $0.2 \mathrm{mi}$. North of Marsh Creek Road, 100 feet East of Walnut Avenue, 15 feet from Southwest corner of house

BR-48 1614 Payne Avenue, $0.45 \mathrm{mi}$. West of Sellers Avenue, 70 feet South of Payne Avenue, at Southwest corner of house 

South of Sand Creek Road at Southwest comer of house

BR-50 $0.25 \mathrm{mi}$. East of Fairview Avenue, 150 yards South of Minnesota Avenue at west side of house

BR-51 1091 Balfour Road (Ford Mustang Parts Store), $0.1 \mathrm{mi}$. West of Minnesota Avenue, 100 yards North of Balfour. Well is inside garage on

BR-52 Southwest comer of the East bay of the garage 1914 Lone Oak Road, $0.1 \mathrm{mi}$. South of Grant Avenue, 50 yards East of Lone Oak Road, 30 feet from Southwest comer of first South-facing cinder block house

BR-53 12 Dove Court, 50 feet East of Dove Court, 150 feet South of Randy Lane, 40 feet from Southeast corner of house

BR-54 1451 Vintage Drive, $0.85 \mathrm{mi}$. North of Lone Tree Way, $0.4 \mathrm{mi}$. West of O'Hara Avenue on Vintage Drive, well located 100 yards past bend to South in road, and 100 yards East of house

BR-55 3490 Sellers Avenue, $1 \mathrm{mi}$. North of Chestnut Avenue, 100 feet East of Sellers Avenue at Northeast corner of house

BR-56 $0.1 \mathrm{mi}$. South of Grant Avenue, 5 feet West of Hwy 4, North of Marsh Creek

BR-57 2300 Chestnut Avenue, $0.25 \mathrm{mi}$. East of Eden Plains Road, 20 yards North of Chestnut Avenue

BR-58 7480 Brentwood Boulevard (Hwy 4), $0.4 \mathrm{mi}$. South of Sunset Avenue, 100 feet East-Southeast of signal light at Hwy 4 and Sand Creek Road

BR-59 2830 PennyLane, $0.5 \mathrm{mi}$. North of Orwood Road, $0.1 \mathrm{mi}$. West of Byron Hwy on North side of PennyLane, 100 feet from Southwest corner of house

BR-60 1760 Green Acres Way, $0.25 \mathrm{mi}$. South of Sunset Avenue, $0.15 \mathrm{mi}$. West of Eden Plains Road, 20 feet East of Green Acres Way

BR-61 2865 Crystal Lane, $0.25 \mathrm{mi}$. North of Orwood Avenue, $0.15 \mathrm{mi}$. West of Byron Hwy, $0.1 \mathrm{mi}$. South on long drive, 20 feet North of house

BR-62 Del Porto Ranch, 0.4 mi. North of Sunset Avenue, 100 yards West of Byron Hwy, Northeast of long stable

BR-63 0.9 mi. East of Byron Hwy on Orwood Road, 0.2 mi. North of Orwood Road on Bixler Road, 10 feet North of green and white machine shed

BR-64 0.65 mi. North of Point of Timber Road, 100 yards West of Bixler Road, Northeast of house, Southwest of shed

BR-65 $0.25 \mathrm{mi}$. West of Bixler Road, 100 yards North of Point of Timber Road, Southwest of old barn used for tractor repairs

BR-66 $0.25 \mathrm{mi}$. East of Byron Hwy, 200 yards South of Delta Road on Mercer Avenue, 300 feet South of house at South wall of old barn

BR-67 3460 Orwood Road, $0.4 \mathrm{mi}$. East of Byron Hwy, 150 yards North of Orwood Road 
BR-68

BR-69

BR-70-1

BR-70-2

BR-70-3

BR-71

BR-72

BR-73

BR-74

BR-75

BR-76

BR-77

BR-78

BR-79

BR-80

BR-81

BR-82

BR-83

BR-84

BR-85

1130 Sunset Road, $0.2 \mathrm{mi}$. East of Sellers Avenue, $0.1 \mathrm{mi}$. North of Sunset Road, 50 yards South of house

3921 Delta Road, $0.9 \mathrm{mi}$. East of Byron Hwy, 0.1 mi. South of Delta Road, 50 feet North of tractor workshop

2700 Concord Avenue, $0.25 \mathrm{mi}$. West of Walnut Avenue, 40 yards South of Concord Avenue, 60 yards Northeast of house

2700 Concord Avenue, $0.25 \mathrm{mi}$. West of Walnut Avenue, 70 yards Southwest of house

2700 Concord Avenue, $0.25 \mathrm{mi}$. West of Walnut Avenue, 20 feet South of house

Delta Growers, $0.75 \mathrm{mi}$. South of Marsh Creek

Road, 100 yards East of Hoffman Lane, North of greenhouses

$0.1 \mathrm{mi}$. South of intersection of Sellers Avenue and Marsh Creek Road, 30 yards Northeast of house

1907 Fertado Road, 0.75 mi East of Hwy 4, 0.2 mi. North of Marsh Creek Road, 100 feet East of Fertado Road, East of Southeast corner of house 7620 Balfour Road, $0.15 \mathrm{mi}$. East of Byron Hwy, 150 yards South of Balfour Road, 20 feet East of Southeast comer of house

25071 Marsh Creek Road, $0.3 \mathrm{mi}$. East of

Southern Pacific Railroad tracks, $1 \mathrm{mi}$. East of Sellers, 30 yards North of Road, 30 feet from Southwest comer of house Liberty Union High School, between Spruce and Second Streets at Hwy 4, 20 feet Northeast from Northeast comer of North parking lot

Edna Hill Elementary School, Corner of Birch and Second Streets at dead end of Cesa Road, well Northwest of maintenance shed

Brentwood City Park Irrigation Well, 100 yards west of City Hall, 10 feet South of Library. 440 Sand Creek Road, $0.1 \mathrm{mi}$. West of Lone Oak Way, 40 yards South of Sand Creek Road 2905 Taylor Lane, $0.15 \mathrm{mi}$. West of Byron Hwy, $0.1 \mathrm{mi}$. North of Taylor Lane, 20 feet North of house

2445 Taylor lane, $0.65 \mathrm{mi}$. West of Byron Hwy, $0.15 \mathrm{mi}$. West of irrigation canal, 20 feet West of Southwest corner of house

Missionary Babtist Church, $0.3 \mathrm{mi}$. North of Hwy 4, $0.1 \mathrm{mi}$. West of Sellers Avenue, 20 yards East of Southeast corner of church

Gonzales Trucking, $0.5 \mathrm{mi}$. East of Sellers

Avenue, $0.1 \mathrm{mi}$. North of Marsh Creek Road, 30 yards West of railroad tracks, 60 yards North of Northern-most brick building

$0.4 \mathrm{mi}$. South of Balfour Road, 100 yards West of Byron Hwy, 20 yards south of house

$0.25 \mathrm{mi}$. South of Main Canal, $0.1 \mathrm{mi}$. North of intersection of Byron Hwy and Hwy 4, 250 feet West of Byron Hwy, 20 feet West of large green machine shed 
BR-86

BR-87

BR-88

BR-89

BR-90

BR-91

BR-92
$0.6 \mathrm{mi}$. North of Chestnut Avenue, approx 50 yards East of Sellers Avenue,

La Paloma High School, $0.1 \mathrm{mi}$. East of Empire Avenue, 50 feet South of Lone Tree Way, at West side of Northwestern-most building Discovery Bay well \#5, 100 yards North of Hwy 4, 50 feet West of intersection of Clipper Road and Newport

Discovery Bay well \#4, $0.1 \mathrm{mi}$. North of Highway 4 on East side of main entrance road to Discovery Bay, 30 yards North of Clipper Road, 20 yards East of road

Discovery Bay well \#3, $0.25 \mathrm{mi}$. North of Clipper Road on main road, 20 feet East of main road Discovery Bay well $\# 2,100$ yards South of intersection of River Lake and the main road, 20 feet east of the main road

Discovery Bay well \#1, $0.4 \mathrm{mi}$. North of BR-91, 50 yards East of the main road on easement between two houses 